\title{
Does Scale Matter in Community Bank Performance? Evidence Obtained by Applying Several New Measures of Performance*
}

\author{
JOSEPH P. HUGHES \\ RUTGERS UNIVERSITY \\ JULAPA JAGTIANI \\ FEDERAL RESERVE BANK OF PHILADELPHIA \\ LORETTA J. MESTER

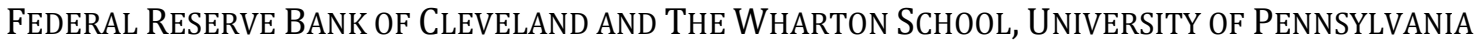 \\ CHOON-GeOL MoON \\ HANYANG UNIVERSITY
}

FEBRUARY 2018

REVISED MAY 2019

\begin{abstract}
We consider how size matters for banks in three size groups: small community banks with assets less than $\$ 1$ billion, large community banks with assets between $\$ 1$ billion and $\$ 10$ billion, and midsize banks with assets between $\$ 10$ billion and $\$ 50$ billion. To illustrate the differences between these banks and larger banks whose business models are distinctly different, we examine large banks with assets between $\$ 50$ billion and $\$ 250$ billion and the largest banks with assets exceeding $\$ 250$ billion. Community banks have potential advantages in relationship lending compared with large banks. However, increases in regulatory compliance and technological burdens may have disproportionately increased community banks' costs, raising concerns about small businesses' access to credit. Our evidence suggests several patterns: (1) while small community banks exhibit relatively more valuable investment opportunities, larger community banks, midsize banks, and larger banks exploit theirs more efficiently and achieve better financial performance; (2) average operating costs that include costs related to regulatory compliance and technology decrease with size; (3) unlike small community banks, large community banks have financial incentives to increase lending to small businesses; and (4) for business lending and commercial real estate lending, compared with small community banks, large community banks, midsize banks, and larger banks assume higher inherent credit risk and exhibit more efficient lending. Thus, concern that small business lending would be adversely affected if small community banks find it beneficial to increase their scale is not supported by our results.
\end{abstract}

Keywords: community banking, scale, financial performance, small business lending JEL Codes: G21, L25

\footnotetext{
* Joseph P. Hughes, Department of Economics, Rutgers University, New Brunswick, NJ 08901-1248, jphughes@rci.rutgers.edu; Julapa Jagtiani, Special Advisor, Supervision, Regulation, and Credit, Federal Reserve Bank of Philadelphia, Ten Independence Mall, Philadelphia, PA 19106, julapa.jagtiani@phil.frb.org; Loretta J. Mester, President and CEO, Federal Reserve Bank of Cleveland, 1455 E. 6th Street, Cleveland, OH 44114, Loretta.Mester@clev.frb.org; Choon-Geol Moon, Department of Economics and Finance, College of Economics and Finance, Hanyang University, Seoul 04763, Korea, mooncg@gmail.com.
}

This paper supersedes J.P. Hughes, J. Jagtiani, L.J. Mester, and C-G. Moon, "Does Scale Matter in Community Bank Performance? Evidence Obtained by Applying Several New Measures of Performance," Federal Reserve Bank of Philadelphia Working Paper 18-11 (Rutgers University Economics Working Paper 201803), and J.P. Hughes, J. Jagtiani, and L.J. Mester, “Is Bigger Necessarily Better in Community Banking?” Federal Reserve Bank of Philadelphia Working Paper 16-15 (Rutgers University Economics Working Paper 201604).

Hughes thanks the Whitcomb Center for Research in Financial Services at the Rutgers Business School for its support of data services used in this research. We thank Dan Milo, Raman Maingi, and Leigh-Ann Wilkins for their research assistance.

Disclaimer: This working paper represents preliminary research that is being circulated for discussion purposes. The views expressed in this paper are solely those of the authors and do not necessarily reflect those of the Federal Reserve Bank of Philadelphia, the Federal Reserve Bank of Cleveland, or the Federal Reserve System. Any errors or omissions are the responsibility of the authors. 


\section{Does Scale Matter in Community Bank Performance? Evidence ObTained by Applying Several New Measures of Performance}

Community bankers live and work where they do business, and their institutions have deep roots, sometimes established over several generations. They know their customers and the local economy. Relationship banking is therefore at the core of community banking. The largest banks typically rely heavily on statistical models to assess borrowers' capital, collateral, and capacity to repay, and those approaches can add value, but banks whose headquarters and key decision makers are hundreds or thousands of miles away inevitably lack the in-depth local knowledge that community banks use to assess character and conditions when making credit decisions. This advantage for community banks is fundamental to their effectiveness and cannot be matched by models or algorithms, no matter how sophisticated.

Ben Bernanke, speech at the Independent Community Bankers of America National Convention, San Diego, California, March 23, 2011

\section{Introduction}

A body of research has shown that community banks have potential advantages in relationship lending compared with large banks, although newer research suggests that these advantages may be shrinking. In addition, community bankers often cite increased regulatory burden and the need to increase investment in technology as having raised their costs. Increased regulatory burden and increased investment in technology have fixed-cost components and so may have disproportionately raised community banks' costs, with the potential to impact their ability to meet local demand or expand beyond their local communities.

Larger banks have been shown to experience cost-reducing diversification and a greater ability to spread operating costs over their larger scale. Studies that have found evidence of these scale economies at even the largest financial institutions include Beccalli, Anolli, and Borello (2015), Dijkstra (2017), Feng and Serletis (2010), Hughes and Mester (2013b), and Wheelock and Wilson (2012). Kovner, Vickery, and Zhou (2014) examined operating costs and their components and found evidence of significant economies related to spreading these costs over a larger scale. In many of these studies, the largest institutions experienced the largest scale economies.

Nevertheless, these scale-related features of cost do not provide definitive evidence that the overall financial performance of larger banks exceeds that of smaller banks. The business model of 
community banks based on relationships in their local communities may well afford them more profitable investment opportunities than those of larger banks.

We add to the cost economies literature in banking by using traditional and new innovative measures of performance to consider how current profitability and discounted future profitability, which are captured in market value, are related to the value of investment opportunities and to scale. In particular, we ask how the value of investment opportunities varies with bank scale and how well banks exploit these investment opportunities. We find that small community banks exhibit weaker financial performance and investigate whether it results from poorer investment opportunities or from less efficient investment strategies, and whether the relatively high rate of nonperformance of their loans results from inherent credit risk or from less efficient lending.

We find that community banks do indeed experience, on average, more valuable investment opportunities but do not exploit them as effectively as larger banks. We also find that small community banks exhibit a relatively high rate of nonperforming business loans and commercial real estate loans that result from less effective credit evaluation and loan management and not from lending to riskier borrowers who default more often.

\subsection{Measuring Performance and the Value of Investment Opportunities}

We develop and apply several new measures of performance to investigate community banking and to compare it with larger banks. In addition to standard measures of performance Tobin's $q$ ratio, return on assets (ROA), risk-adjusted ROA, and ratios of operating cost to revenue and revenue to assets - we use stochastic frontier estimation to gauge a bank's best-practice performance and the extent of its failure to achieve the best practice. First, we estimate for each bank its highest potential market value of assets as a function of its book-value investment in assets. We term this highest potential value the best-practice value or, more accurately, the best observed value. The difference between the highest potential value and the noise-adjusted observed value is lost market value, and when lost value is normalized by the highest potential 
value, the ratio gives lost value as a proportion of best-practice value - market-value inefficiency. $^{2}$

Second, we adapt this frontier technique to develop a new measure of performance: each bank's best-practice ROA as a function of its ROA risk and its asset size. A bank's ROA risk is gauged by the five-year standard deviation of its ROA. ${ }^{3}$ The difference between the best practice and the noise-adjusted achieved ROA gauges the extent of each bank's lost potential return given its return risk and scale.

When the estimation of the highest potential market value includes variables that capture the economic conditions in banks' local markets, the highest potential value gauges the value of banks' investment opportunities in their particular markets. Many studies use Tobin's $q$ ratio to gauge investment opportunities, but it is not independent of the particular bank's performance which may be impacted by agency problems. The frontier measure of the value of any individual bank's investment opportunities is independent of the bank's performance and is derived from the estimated upper envelope of market values of all banks conditioned on their local market characteristics. This potential market-value measure represents the value of a bank in a competitive auction, i.e., its charter value. When it is normalized by the book-value investment in its assets, it provides an investment opportunity ratio that can be compared across banks of different sizes. In particular, we find that small community banks obtain, on average, the lowest Tobin's $q$ ratio of the five size groups we define. The low $q$ ratio could result from relatively lowvalue investment opportunities; however, we find that small community banks experience, on average, the highest investment opportunity ratio of the size groups. Moreover, they also exhibit the highest average market-value inefficiency ratio, which indicates that they do not exploit their investment opportunities as effectively as larger banks. Thus, their low average q ratio does not result from poor investment opportunities.

\footnotetext{
${ }^{2}$ Hughes, Lang, Moon, and Pagano (1997) proposed these concepts, which have been applied in numerous studies. See Hughes and Mester (2015) for examples.

${ }^{3}$ Stiroh and Rumble (2006) use this measure of risk to gauge risk-normalized return.
} 


\subsection{Lending Performance - Distinguishing Nonperformance Due to Inherent Credit Risk from Nonperformance Due to Lending Inefficiency}

Finally, we measure and compare the lending performance of community banks with that of larger banks. We apply a technique developed by Hughes and Moon (2017) to distinguish nonperformance due to less effective credit evaluation and loan monitoring from nonperformance due to the bank's choice of the inherent credit risk of its loans. We focus on two types of loans: business loans and commercial real estate (CRE) loans. We use a stochastic frontier technique to estimate a bank's best-practice (i.e., minimum) ratio of nonperforming business loans to total business loans and best-practice ratio of nonperforming CRE loans to total CRE loans, controlling for the amount held of this type of loan, total loan volume, and factors related to credit risk and to the economic conditions in the markets in which the bank operates. The minimum ratio represents the best-observed-practice nonperformance controlling for the loan volume and other factors that capture inherent credit risk. It indicates the lowest nonperforming loan ratio the bank could achieve if it were fully efficient at credit-risk evaluation and loan monitoring. The difference between a bank's achieved nonperforming loan ratio adjusted for noise and its best-observedpractice ratio - its excess nonperforming loan ratio - gauges its efficiency at credit analysis and loan monitoring. Compared with larger banks, on average, small community banks experience the highest rate of nonperformance of business loans and CRE loans, which results from the highest rate of inefficiency at lending rather than high inherent credit risk.

\subsection{The Data}

We focus on 2013 data on 761 top-tier bank holding companies (BHCs), whose assets are consolidated across all constituent subsidiaries to investigate performance differences of banks in three size categories: small community banks with assets less than $\$ 1$ billion, large community banks with assets between $\$ 1$ billion and $\$ 10$ billion, and midsize banks with assets between $\$ 10$ billion and $\$ 50$ billion. The business strategies of banks in these three groups are more similar than those of larger banks. To illustrate the differences between these banks and larger banks, we include large banks with assets between $\$ 50$ billion and $\$ 250$ billion and the largest banks with assets 
exceeding $\$ 250$ billion. There are 335 small community banks, 357 large community banks, 40 midsize banks, 18 large banks, and 11 largest banks in the sample. ${ }^{4}$

For the 268 publicly traded banks in the sample, we augment their financial accounting data with performance measures based on their market value. The publicly traded sample allows us to compare accounting measures of current performance with the market's expectation of discounted future profitability. Although publicly traded firms represent only about 30 percent of the community banks, this smaller sample gives important evidence of the value of investment opportunities and investment incentives provided by the capital market. The performance results based on the publicly traded sample largely confirm the results from the larger sample and indicate differences in capital market incentives to make small business loans (SBLs) across the five categories of bank sizes. And the publicly traded sample gives us the ability to estimate how the value of investment opportunities differs between community banks and larger banks and to evaluate the effectiveness of these banks in exploiting their opportunities.

In addition to data from 2013 representing the period five years following the financial crisis, we also examine 2003 data capturing the period five years before the crisis. Finally, we consider more recent data from 2016, when the fintech phenomenon began to gain traction. The 2003 data and 2016 data include information on 1235 BHCs and 493 BHCs, respectively. In 2015, the reporting requirements changed so that most BHCs with less than $\$ 1$ billion in assets are no longer required to file the Y9-C report. Thus, after 2015, the number of small community banks is sharply reduced, so we take extra care in drawing conclusions for this later year.

\subsection{The Findings}

In 2003,2013 , and 2016, our results indicate that small community banks generally experience higher overall average operating costs compared with large community banks and larger banks. While banks of all sizes obtain essentially the same average revenue per dollar of

\footnotetext{
${ }^{4}$ The data set includes independent banks not owned by another company and the top-tier holder of institutions with multiple subsidiaries (with assets and liabilities consolidated across all constituent subsidiaries). The accounting data are from the Y-9C BHC consolidated financial statements.
} 
assets in the three years of our samples, large community banks, midsize banks, and both groups of larger banks achieve, on average, a higher ROA than small community banks. ${ }^{5}$

We investigate whether this higher average ROA of larger banks results from more profitable investment opportunities or from greater efficiency at exploiting their investment opportunities. Applying stochastic frontier techniques, we find that the potential (best-practice) ROA at small community banks is, on average, smaller than that of the other larger size groups. And, in 2013, we gauge the potential ROA of banks in their local markets and find that, again, small community banks obtain, on average, a lower potential ROA. Moreover, in each of the three years, small community banks achieve less of their potential ROA (higher ROA shortfall) than large community banks and midsize banks. Thus, the lower average achieved ROA of community banks results from a lower potential ROA and a lower efficiency at achieving their potential.

The higher average accounting return achieved by the larger banks in the full sample is confirmed by the publicly traded sample's market-value measures of performance. As in the case of the ROA and ROA efficiency, in each of the three years, Tobin's $q$ ratio is, on average, generally lower at small community banks than at larger banks.

As in the case of the ROA, we find that in each of the three years, large community banks, midsize banks, and larger banks, on average, achieve relatively more of their potential market value than small community banks. In contrast, the relative market value of their investment opportunities is lower than that of small community banks, which suggests that these larger banks appear to exploit their investment opportunities more effectively than small community banks.

Research suggests that small community banks experience advantages in relationship lending compared with larger banks. ${ }^{6}$ Our analysis considers 2013 and indicates that, compared with larger banks, small community banks' relatively higher average ratio of nonperforming

\footnotetext{
${ }^{5}$ When ROA is normalized for risk measured by the standard deviation of return, large community banks and midsize banks achieve a higher risk-normalized ROA than small community banks in each of the three years. However, the higher ROA of larger banks, when normalized by risk, is not consistently higher than that of small community banks.
}

${ }^{6}$ Berger and Udell (2006) discuss the literature on small business finance. 
business loans reflects a lower best-practice nonperforming loan ratio (i.e., lower inherent credit risk) and a relatively higher nonperformance ratio in excess of best practice (i.e., less lending efficiency). In the case of CRE loans, small community banks again, on average, obtain the highest rate of nonperformance; however, the best-practice ratio is similar across all five size groups so, on average, the higher nonperformance rate at small community banks is due to lower CRE lending efficiency than at banks in the larger size groups.

Finally, we investigate the incentives to make small business loans (SBLs), a product in which small banks have traditionally had a comparative advantage. Historically, community banks have served as an important source of credit for small businesses, but the SBL market and the economic landscape have significantly changed in recent years. Jagtiani and Lemieux $(2016,2018)$ discuss how advanced technology has allowed large banks and nonbank alternative lenders to become more important providers of SBLs since the latter part of the 2000s. The fixed cost required to invest in technology may have affected the efficiency and performance at small community banks in recent years.

Using Call Report data on SBLs (i.e., small commercial and industrial (C\&I) loans) with origination amounts of less than $\$ 1$ million, we find in 2013 no difference in the ratio of SBLs to assets at small and large community banks. ${ }^{7}$ Accounting measures of performance in 2013 indicate that financial performance is positively related to the ratio of SBLs to assets at small and large community banks, but market-value measures, which account for expected future as well as current profitability discounted at a rate that reflects market-priced risk, suggest that small business lending enhances market value at large community banks and erodes market value at small community banks.

${ }^{7}$ Different studies in the literature use different sources of data and therefore use different definitions of SBL. Call Reports define SBLs as C\&I loans with origination amounts of less than \$1 million, regardless of whether the borrowers are actually small. The Community Reinvestment Act defines SBLs as loans made to small businesses with less than $\$ 1$ million in annual gross revenue. The Federal Reserve Survey of Small Business Finance defines SBLs as loans made to small businesses with fewer than 500 employees (regardless of loan size). Because of these different definitions, results may not be comparable across studies. 
Overall, our results provide evidence that, on average, large community banks outperform small community banks and are more efficient at assessing credit risk and at monitoring both business loans and commercial real estate loans, and that midsize banks financially outperform community banks. Moreover, large banks and the largest banks generally outperform small community banks and achieve more of their potential market value. Thus, there appear to be incentives for small banks to grow larger to exploit scale economies and to achieve other scalerelated benefits in terms of lending efficiency. In addition, we find that SBLs are an important factor explaining large community banks' better performance compared to small community banks. Thus, the concern that small community banks would curtail their small business lending if these banks decide to increase their scale is not supported by our results.

The rest of this paper is organized as follows. Section 2 provides a brief literature review. Section 3 describes the data. Section 4 discusses the accounting-based and market-value-based measures of financial performance and the empirical findings on the relationship between bank size (scale) and the various measures of performance. Section 5 considers the degree to which community banks are handicapped by spreading operating costs over a small scale. Section 6 explores differences in investment strategies by bank size that can influence performance. Section 7 presents results that decompose the difference in nonperformance into the inherent credit risk of the borrowers to whom the bank lends and the effectiveness with which the bank evaluates and monitors loans to these borrowers. Section 8 investigates whether the differences in performance we found by bank size provide financial incentives for small community banks to grow larger and to change their investment strategy, in particular, lending to small businesses. Section 9 concludes.

\section{Review of the Literature on Small Business Lending by Community Banks versus Larger Banks}

Previous studies, including those by Berger, et al. (2005); Chakraborty and Hu (2006); Beccalli and Frantz (2013); and Kowalik (2014) have documented support for the traditional view 
that small community banks have advantages in monitoring their customers through personal relationships. According to this view, unlike large banks that tend to serve larger firms, on which there is more publicly available information, small community banks play a special role in supporting small businesses in their local communities because they are better able to form strong relationships with small opaque firms.

However, this traditional view has been challenged in more recent studies. Berger and Udell (2006) find that large banks are, in fact, not disadvantaged when providing credit to informationally opaque small firms. They explain the conflicting evidence obtained by some studies that use international data and find that small banks' advantage in small business lending may be driven by the fact that lending technologies available in the U.S. may not be used in other countries. Studies based on U.S. data, including Berger, Frame, and Miller (2005) and Berger, Cowan, and Frame (2011), find that technologies such as small business credit scoring have somewhat replaced the traditional banking relationships and have allowed large banks to increase their small business lending at a lower cost than small community banks. Mester (1999) discusses the access to credit of small businesses and the entry of larger banks into the SBL market.

Similarly, DeYoung, et al. (2011) and Petersen and Rajan (2002) note that the distance between small business borrowers and lenders has been increasing as a result of changes in lending technology, such as the adoption of credit scoring technologies by the lending banks. The motivation for this expansion is not clear; it appears that loans made to borrowers located closer to the lending bank perform better. DeYoung, Glennon, and Nigro (2008) find that borrowers at least 25 miles away from their bank lenders were 10.8 percent more likely to default on their loans, and borrowers located at least 50 miles away were 22.1 percent more likely to default on their loans. DeYoung, et al. (2008) find that, in addition to the significant movement toward automated lending technology in recent years, small businesses have increasingly relied on larger banks as their funding sources. Prager and Wolken (2008) confirm this, using the 2003 Survey of Small Business 
Finance data; they find that 70 percent of small businesses cite a big bank as their primary financial institution, but only 25 percent cite a community bank, and 5 percent cite a nonbank institution.

More recent studies, using data after the financial crisis, such as Berger, Goulding, and Rice (2014) and Berger, Cerqueiro, and Penas (2014), provide supporting evidence of the increasing roles that large banks play in lending to small business and to start-up firms. In addition, Jagtiani, Kotliar, and Maingi (2016) investigate bank mergers announced during the period 2000-2012 and find no adverse impact on overall small business lending even after the community bank merger targets became part of the large acquiring banks. In fact, they find that post-merger, the merged banking firm's small business lending tended to exceed the pre-merger small business lending of the target and acquirer; i.e., small business lending increased after community bank targets became larger via the merger.

In addition to small businesses obtaining more of their funding from large banks, previous studies have also shown that small businesses have increased their use of nontraditional credit, such as loans from nonbank institutions and business credit cards, funded by large banks and nonbank institutions. Mester, Nakamura, and Renault (2007) report that finance companies were responsible for an increasing share of loans to businesses over time, reaching one-third by 2006. Using a longer sample period that includes more recent data after the financial crisis, Jagtiani and Lemieux $(2016,2018)$ confirm that nonbank institutions have been increasing their role in the small business lending market through online lending platforms. ${ }^{8}$

\section{The Data}

We use 2013 data on 761 top-tier bank holding companies to measure performance and investment strategies. For a check on robustness of the results for 2013 , five years after the financial crisis, we also consider data from 2003, five years before the crisis, and 2016, a year in which the fintech industry began to gain traction. While we include banks larger than $\$ 50$ billion,

8 They also suggest ways to enhance potential cooperation, such as partnerships between large banks and community banks or between banks and nonbank lenders. 
our study focuses on banks with assets less than $\$ 50$ billion. These smaller banks encompass small and large community banks and midsize banks. Small community banks are banks with assets of less than $\$ 1$ billion, and large community banks are banks with assets between $\$ 1$ billion and $\$ 10$ billion. While the business models of community banks generally differ from those of larger banks, we include in our focus the next group of banks larger than community banks (midsize banks with assets between $\$ 10$ billion and $\$ 50$ billion) to consider the incentives of community banks to grow larger. The 2013 sample of community banks and midsize banks comprises institutions with assets ranging from $\$ 92.7$ million to $\$ 47.1$ billion. In the 2013 sample, there are 335 small community banks and 357 large community banks. We contrast these two groups with the sample's 40 midsize banks, whose assets fall between $\$ 10$ billion and $\$ 50$ billion; the 18 large banks, holding assets between $\$ 50$ billion and $\$ 250$ billion; and the 11 largest banks, with assets exceeding $\$ 250$ billion. Among the 761 top-tier holding companies, 268 are publicly traded.

We draw on several sources for our data: market-value information from Compustat, accounting data from the end-of-year Y9-C reports filed with regulators, and data used to determine the geographic reach of banks from the Summary of Deposits obtained from the Federal Deposit Insurance Corporation (FDIC). Because the Y9-C data do not report SBLs at the level of the consolidated top-tier holding company, we collect data on outstanding SBLs from the end-of-year bank-level Call Reports and sum them to the top-tier holding company level using the Federal Reserve Structure Database.

\section{Financial Performance and the Value of Investment Opportunities}

\subsection{Accounting Measures}

\subsubsection{Return on Assets and Risk-Normalized Return on Assets}

We base several measures of performance on accounting data. Profit is gauged by the net income component of the Y-9C Report (BHCK4301): “Income (loss) before income taxes and extraordinary items, and other adjustments." ROA (return on assets) is given by profit divided by 
consolidated assets (BHCK2170). ${ }^{9}$ Risk-normalized ROA is measured by the bank's ROA divided by the standard deviation of its ROA. The standard deviation is calculated over the five-year period 2009-2013.

\subsubsection{Return Shortfall}

Does a finding that the mean achieved ROA of one group of banks is higher than another reflect the first group's relatively more valuable investment opportunities, greater efficiency in exploiting investment opportunities, or both? To address this question, we estimate an upper envelope of observed ROA as a function of ROA risk and consolidated assets to distinguish between best-practice ROA and ROA efficiency: how much of best-practice ROA is achieved after eliminating the influence of statistical noise (luck). ${ }^{10}$ Thus, we augment the standard measures of ROA by the best-practice ROA and risk-normalized best-practice ROA, which can be interpreted as estimates of the value of investment opportunities available to a bank, and ROA shortfall and risknormalized ROA shortfall, which are measures of the bank's inefficiency at exploiting its investment opportunities. For example, consider two banks: one that exhibits ROA of 3 percent and the other, 4 percent. Suppose the potential ROA of the first bank is 3.5 percent and that of the second bank is 5 percent. Then the ROA of the first bank is lower than that of the second bank, but it has achieved more of its potential, with a shortfall from potential of only 0.5 percentage point compared with a shortfall of 1.0 percentage point for the second bank.

To obtain the best practice and shortfall, we use stochastic frontier techniques to estimate an upper envelope of observed ROA as a quadratic function of ROA risk (ROASTD) and risk interacted with the log transformation of the consolidated book-value of assets net of goodwill.11 The frontier value estimates the best-practice ROA observed in the sample for given values of consolidated assets and ROA risk after eliminating noise (luck). The shortfall of a bank's actual ROA

\footnotetext{
${ }^{9}$ The findings based on the return on equity are qualitatively similar so we do not report them. We focus instead on the return on assets because the return on equity is substantially influenced by leverage.

${ }^{10}$ To be clear, this is an empirical study, and we can only identify the best practice we observe in our sample and not the theoretically best practice.

${ }^{11}$ Bauer (1990) and Jondrow, et al. (1982) describe the stochastic frontier technique in detail.
} 
from this best-practice ROA gauges how efficient the bank is in achieving this best-practice performance. ${ }^{12}$

More specifically, we use maximum likelihood techniques to estimate a quadratic frontier:

$$
\begin{aligned}
R O A_{i}=\beta_{0}+ & \beta_{1}\left(\operatorname{ROASTD}_{\mathrm{i}}\right)+\beta_{2}\left(\operatorname{ROASTD}_{\mathrm{i}}\right)\left(\ln \left(\text { assets }_{i}\right)\right) \\
& +\beta_{3}\left(\operatorname{ROASTD}_{i}\right)^{2}+\beta_{4}\left(\text { ROASTD }_{i}\right)^{2}\left(\ln \left(\text { assets }_{i}\right)\right)+\varepsilon_{i},
\end{aligned}
$$

where $\varepsilon_{i}=v_{i}-\mu_{i}$ is the sum of a two-sided, normally distributed error term, $v_{i} \sim$ iid $N\left(0, \sigma_{v}{ }^{2}\right)$, that captures statistical noise, and a one-sided, positive, and exponentially distributed error term, ${ }^{13}$ $\mu_{i}, \mu_{i}(>0) \sim \theta \exp (-\theta u)$, that gauges the systematic shortfall from best practice. The results of this estimation are reported in Appendix A, Table A1. We measure a bank's best-practice ROA by

$$
\begin{aligned}
\text { Best-Practice } \text { ROA }_{\mathrm{i}}=\beta_{0}+\beta_{1}\left(\operatorname{ROASTD}_{\mathrm{i}}\right)+\beta_{2}\left(\operatorname{ROASTD}_{\mathrm{i}}\right)\left(\ln \left(\text { assets }_{i}\right)\right) \\
+\beta_{3}\left(\text { ROASTD }_{i}\right)^{2}+\beta_{4}\left(\operatorname{ROASTD}_{i}\right)^{2}\left(\ln \left(\text { assets }_{i}\right)\right) .
\end{aligned}
$$

We gauge a bank's ROA shortfall by the expectation of $\mu_{i}$, the one-sided error term, conditional on $\varepsilon_{i,}$, the composite error term:

$$
\operatorname{ROA}_{\text {Shortfall }}=E\left(\mu_{i} \mid \varepsilon_{i}\right)
$$

We measure noise by the expectation of $v_{i}$, the two-sided error term, conditional on $\varepsilon_{i}$, the composite error term:

$$
\text { Noise }_{i}=E\left(v_{i} \mid \varepsilon_{i}\right)=\varepsilon_{i}+E\left(\mu_{i} \mid \varepsilon_{i}\right)
$$

Thus, the frontier estimation decomposes the observed ROA into three components: the bestpractice ROA, the ROA shortfall from best-practice ROA, and noise:

$$
\begin{aligned}
\text { ROA }_{i}= & \text { Best }_{-} \text {Practice }_{\text {ROA }_{i}}-\text { ROA Shortfall }_{i}+\text { Noise }_{i} \\
= & \beta_{0}+\beta_{1}\left(\text { ROASTD }_{\mathrm{i}}\right)+\beta_{2}\left(\text { ROASTD }_{\mathrm{i}}\right)\left(\ln \left(\text { assets }_{i}\right)\right) \\
& \quad+\beta_{3}\left(\operatorname{ROASTD}_{i}\right)^{2}+\beta_{4}\left(\operatorname{ROASTD}_{i}\right)^{2}\left(\ln \left(\text { assets }_{i}\right)\right)-E\left(\mu_{i} \mid \varepsilon_{i}\right)+E\left(v_{i} \mid \varepsilon_{i}\right) .
\end{aligned}
$$

Statistical noise can be subtracted from ROA to obtain the noise-adjusted observed ROA,

\footnotetext{
12 We use the term potential ROA, but recognize that this is the best-practice ROA observed in the sample and not necessarily the best practice that could ever be achieved.

${ }^{13}$ The AIC (BIC) and Vuong's test for relative explanatory power favor the exponential distribution of the onesided error term over the half-normal distribution.
} 
Noise-Adjusted Observed ROA $A_{i}=R O A_{i}-E\left(v_{i} \mid \mathcal{E}_{i}\right)$.

ROA shortfall, given in Equation (3), can be expressed as the difference between the best-practice ROA and the noise-adjusted observed ROA:

$$
\begin{aligned}
\text { ROA Shortfall }_{i}= & E\left(\mu_{i} \mid \mathcal{E}_{i}\right)=\beta_{0}+\beta_{1}\left(\operatorname{ROASTD}_{\mathrm{i}}\right)+\beta_{2}\left(\operatorname{ROASTD}_{\mathrm{i}}\right)\left(\ln \left(\text { assets }_{i}\right)\right) \\
& +\beta_{3}\left(\text { ROASTD }_{i}\right)^{2}+\beta_{4}\left(\text { ROASTD }_{i}\right)^{2}\left(\ln \left(\text { assets }_{i}\right)\right)-\left(\text { ROA }_{i}-E\left(v_{i} \mid \varepsilon_{i}\right)\right) .
\end{aligned}
$$

Figure 1 illustrates achieved ROA, the best-practice ROA, the shortfall from best practice, and noise. In this example, bank $i$ attains an achieved ROA of 1.08 percent. The best-practice ROA is 1.70 percent, which consists of the achieved ROA of 1.08 percent, statistical noise (luck) of -0.02 percent, and an ROA shortfall from best practice of 0.60 percent. The ROA adjusted for noise is $\left(R O A_{i}-v_{i}\right)=1.08-(-0.02)=1.10$ percent. The difference between the best-practice ROA, 1.70 percent, and the noise-adjusted observed ROA, 1.10 percent, represents the ROA shortfall, 0.60.

We can normalize the best-practice ROA and the shortfall by risk:

Risk-Normalized Best-Practice ROA $_{i}=$ Best-Practice $R O A_{i} / R_{\text {ROASTD }}$, and

Risk-Normalized ROA Shortfall S $_{i}$ ROA Shortfall $_{i} /$ ROASTD $_{i}$.

The ROA frontier in Equation (1), by controlling for asset size and ROA risk, evaluates banks' performance in terms of peers with similar asset size and ROA risk. Thus, differences in investment strategy can explain banks' observed performance relative to best-practice performance. If variables characterizing the investment strategy are included in the specification of the frontier, the range of peers is narrowed to those of similar investment strategies as well as asset size and ROA risk. We specify a second ROA frontier that narrows the definition of peers by adding variables to control for the broad investment strategy - capital structure, liquidity, and the importance of lending and off-balance-sheet activities - which is characterized by the ratios of loans to assets, liquid assets ${ }^{14}$ to assets, deposits to total borrowed funds, ${ }^{15}$ equity capital ${ }^{16}$ to

\footnotetext{
${ }^{14}$ Liquid assets are defined as the sum of cash and balances due from financial institutions (BHCK0081, BHCK0395, BHCK0397 from the Y9-C report), securities (BHCK1754, BHCK1773), federal funds sold (BHDMB987), and securities purchased under agreement to resell (BHCKB989).
} 
assets, and noninterest income to total revenue. ${ }^{17}$ We avoid adding more detail, such as the composition of the loan portfolio, since doing so would exclude a suboptimal portfolio from the measurement of efficiency. ${ }^{18}$ The second ROA frontier is given by

$$
\begin{aligned}
& R O A_{i}=\beta_{0}+\beta_{1}\left(\operatorname{ROASTD}_{\mathrm{i}}\right)+\beta_{2}\left(\operatorname{ROASTD}_{\mathrm{i}}\right)\left(\ln \left(\text { assets }_{i}\right)\right)+\beta_{3}\left(\operatorname{ROASTD}_{i}\right)^{2}
\end{aligned}
$$

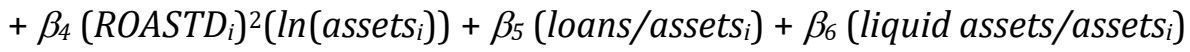

$$
\begin{aligned}
& +\beta_{7}\left(\text { noninterest income } / \text { assets }_{i}\right)+\beta_{8}\left(\text { deposits } /\left(\text { deposits }+ \text { other borrowed funds }_{i}\right)\right. \\
& +\beta_{8}\left((\text { equity }+ \text { sub debt+loan-loss reserves }) / \text { assets }_{i}\right)+\varepsilon_{i},
\end{aligned}
$$

where $\varepsilon_{i}=v_{i}-\mu_{i}$ is the sum of a two-sided, normally distributed error term, $v_{i} \sim$ iid $N\left(0, \sigma_{v}{ }^{2}\right)$, that captures statistical noise, and a one-sided, positive, and exponentially distributed error term, ${ }^{19} \mu_{i}$, $\mu_{i}(>0) \sim \theta \exp (-\theta u)$, that gauges the systematic shortfall from best practice. The results of this estimation are reported in Appendix A, Table A2.

\subsection{Market-Value Measures}

\subsubsection{Tobin's q Ratio}

For the banks that are publicly traded, we also derive several measures of performance based on their market value. Market-value measures of performance offer two advantages. First, while accounting measures gauge current profitability, a firm's market value reflects not just the firm's current cash flow but also the market's expectation of the future cash flow discounted at a rate that reflects the market's assessment of the relevant risk attached to the cash flow. Second,

\footnotetext{
15 Deposits are given by deposits in domestic offices (BHDM6631, BHDM6636 in the Y9-C report). Total borrowed funds are composed of deposits in domestic offices, deposits in foreign offices (BHFN6631, BHFN6636), subordinated debt (BHCK4062), federal funds purchased (BHDMB993), securities sold under agreement to repurchase (BHCKB995), trading liabilities (BHCK3548), and other borrowed money (BHCK3190).

${ }^{16}$ Equity capital is the sum of equity (BHCK3210 from the Y9-C report), subordinated debt (BHCK4062), and loan-loss reserves (BHCK3123) - essentially tier 1 and tier 2 capital.

${ }^{17}$ Revenue is defined as the sum of interest income (BHCK4107 from the Y9-C report) and noninterest income (BHCK4079).

18 The AIC (BIC) and Vuong's test for relative explanatory power favor the characterization of investment strategy by the ratio of loans to assets rather than a decomposition of loans into their important components.

${ }^{19}$ The AIC (BIC) and Vuong's test for relative explanatory power favor the exponential distribution of the onesided error term over the half-normal distribution.
} 
differences in investment incentives of small and large community banks provided by the capital market can be inferred from market-value measures of performance. While the smaller number of publicly traded banks, especially in the case of small community banks, requires caution in drawing conclusions, the investment incentives found in the publicly traded sample are likely to apply to privately held institutions when market discipline encourages their management to pursue market value. $^{20}$

Performance based on market value is frequently measured by Tobin's $q$ ratio, which is defined as the ratio of the market value of assets (MVA) to their replacement cost. We use a common proxy for the MVA of bank $i\left(\mathrm{MVA}_{\mathrm{i}}\right)$, which is the sum of the market value of equity and the book value of liabilities. For replacement cost, we use a standard proxy, bank i's book value of assets net of goodwill $\left(\mathrm{BVA}_{\mathrm{i}}\right)$. Thus,

Tobin's q ratio $=M V A_{i} / B V A_{i .}{ }^{21}$

\subsubsection{Market-Value Inefficiency and the Value of Investment Opportunities ${ }^{22}$}

Similar to the measures we described previously based on ROA, we use stochastic frontier techniques to gauge the market value of investment opportunities and the efficiency of banks in exploiting these investment opportunities. For efficiency measurement we ask: What is the highest market value of a bank's book-value investment in assets across all banking markets? Adjusted for statistical noise, the difference between the highest value and the achieved value measures the bank's lost market value, which can be used to gauge its efficiency. This systematic lost market value captures differences among firms in market advantages as well as differences in managerial consumption of agency goods. Because managers decide the local markets in which their firms

\footnotetext{
${ }^{20}$ Hughes and Mester (2010, 2013a, 2015, forthcoming) provide a comprehensive discussion of methodologies to assess bank performance.

${ }^{21}$ See Hughes and Mester (2010, 2015, forthcoming) for a review of the finance literature that uses Tobin's $q$ ratio to measure performance.

${ }^{22}$ Hughes, Lang, Moon, and Pagano (1997) proposed these concepts, which have been applied in numerous studies. See Hughes and Mester (2015) for examples.
} 
should operate and the capital market prices differences in market advantages, we consider market advantages as components of managerial effectiveness.

As we did for the accounting measure, ROA, we obtain the potential market value of assets by specifying a quadratic function of the bookvalue of assets net of goodwill and by applying maximum likelihood techniques to estimate the frontier:

$$
M V A_{i}=\alpha+\beta\left(B V A_{i}\right)+\gamma\left(B V A_{i}\right)^{2}+\varepsilon_{i},
$$

where $\varepsilon_{i}=v_{i}-\mu_{i}$ is a composite error term. Statistical noise is given by $v_{i} \sim$ iid $N\left(0, \sigma_{v}^{2}\right)$. The systematic shortfall from bank $i$ 's best-practice market value is given by $\mu_{i}$. We assume that $\mu_{i}$ is distributed exponentially, $\mu_{i}(>0) \sim \theta \exp (-\theta u) .{ }^{23}$ The results of this estimation are reported in

\section{Appendix A, Table A3.}

From the estimation of Equation (12), we obtain the best-practice market value, the marketvalue shortfall, and the noise component for bank $i$ (all measured in dollars):

$$
\begin{aligned}
& \text { Best-Practice MVA }=\alpha+\beta\left(B V A_{i}\right)+\gamma\left(B V A_{i}\right)^{2}, \\
& \text { MVA Shortfall }_{i}=E\left(\mu_{i} \mid \varepsilon_{i}\right), \\
& \text { Noise }_{i}=E\left(v_{i} \mid \varepsilon_{i}\right)=\varepsilon_{i}+E\left(\mu_{i} \mid \varepsilon_{i}\right) .
\end{aligned}
$$

Thus, the frontier estimation decomposes the observed MVA into three components: the bestpractice MVA, the MVA shortfall from best-practice MVA, and noise:

$$
\begin{aligned}
& M V A_{i}=\text { Best-Practice } \text { MVA }_{i}-\text { MVA Shortfall } i+\text { Noise }_{i} \\
& =\alpha+\beta\left(B V A_{i}\right)+\gamma\left(B V A_{i}\right)^{2}-E\left(\mu_{i} \mid \mathcal{E}_{i}\right)+E\left(v_{i} \mid \mathcal{E}_{i}\right) .
\end{aligned}
$$

By subtracting luck from the observed MVA, we obtain the noise-adjusted observed MVA,

$$
\text { Noise-Adjusted Observed } M V A_{i}=M V A_{i}-E\left(v_{i} \mid \varepsilon_{i}\right)
$$

The expression in Equation (16) can be rearranged to express the MVA shortfall as the difference between the best-practice MVA and the noise-adjusted observed MVA:

$$
\text { MVA Shortfall }{ }_{i}=E\left(\mu_{i} \mid \varepsilon_{i}\right)=\alpha+\beta\left(B V A_{i}\right)+\gamma\left(B V A_{i}\right)^{2}-\left(M V A_{i}-E\left(v_{i} \mid \varepsilon_{i}\right)\right) \text {. }
$$

${ }^{23}$ The AIC (BIC) and Vuong's test for relative explanatory power favor the exponential distribution of the onesided error term over the half-normal distribution. 
The shortfall is measured in dollars of lost market value. To control for size we normalize the shortfall by the best-practice value to obtain the proportion of potential value systematically lost:

$$
\text { Market-Value Inefficiency } \text { Ratio }_{i}=E\left(\mu_{i} \mid \varepsilon_{i}\right) /\left[\alpha+\beta\left(B V A_{i}\right)+\gamma\left(B V A_{i}\right)^{2}\right] \text {. }
$$

Figure 2 illustrates these measures. In this example, bank $i$ has invested 100 in assets and achieves a market value of 106 . Noise is -2 , so that the MVA adjusted for statistical noise, $\left(M V A_{i}-\right.$ $\left.v_{i}\right)$, is 108 . Its best-practice market value is 120 , and the shortfall from potential value, the difference between the best-practice value and the noise-adjusted observed value, is 12 . Thus, the market-value inefficiency ratio is $0.10(=12 / 120)$.

We can also use the frontier estimation to derive a measure of Tobin's $q$ that is adjusted for noise:

Noise-Adjusted Tobin's q Ratio $=\left[M V A_{i}-E\left(v_{i} \mid \varepsilon_{i}\right)\right] / B V A_{i}$.

Several studies have used the market-value inefficiency ratio or the noise-adjusted Tobin's $q$ ratio to measure performance. ${ }^{24}$

Although Tobin's $q$ ratio is a standard measure in the literature, the market-value inefficiency ratio offers some advantages as a measure of financial performance. First, it removes the influence of luck on performance and measures a firm's systematic failure to achieve its bestobserved value. Since the frontier technique identifies lost market value as well as achieved market value, it gauges the extent of agency problems more directly than Tobin's $q$ ratio, and it allows us to investigate the factors that contribute to firms' failure to achieve their highest potential market value. Consequently, it can uncover differences in investment incentives provided by the capital market.

We derive a second set of measures that looks at the highest potential value of the bank given the markets in which it operates. This allows us to measure the market value of investment opportunities it faces in its markets, in contrast to potential value across all markets in the sample.

\footnotetext{
${ }^{24}$ See, for example, Habib and Ljungqvist (2005); Baele, De Jonghe, and Vander Vennet (2007); De Jonghe and Vander Vennet (2005); Hughes and Moon (2003); Hughes, et all. (1999); Hughes, Mester, and Moon (2001); Hughes, et al. (2003); and Hughes and Mester (2013a, 2013b).
} 
This highest potential value of a bank in the markets in which it operates can be considered its value in a competitive auction - its charter value. In contrast to frequently used measures of the value of investment opportunities, such as the price-earnings ratio and Tobin's $q$ ratio, which can be biased by agency problems, this measure is independent of the managerial decisions of any specific bank.

To obtain this potential value, we amend Equation (12) by adding variables that characterize the economic opportunities of the markets in which a bank operates: the weighted average GDP growth rate $(\boldsymbol{G r o w t h})$ and the weighted average Herfindahl index $\left(\boldsymbol{H e r f}_{\boldsymbol{i}}\right)$ across these markets, where the weights are bank deposit shares. ${ }^{25}$ (We do not include variables that characterize a bank's investment strategy, because this would limit the estimation of the bank's potential value, not just to peers of the same size and market opportunities, but also to peers with similar investment strategies that might be suboptimal.) In particular, we use maximum likelihood to estimate the frontier,

$$
M V A_{i}=\alpha+\beta\left(B V A_{i}\right)+\gamma\left(B V A_{i}\right)^{2}+\gamma_{A G}\left(B V A_{i}\right)\left(\text { Growth }_{i}\right)+\gamma_{A H}\left(B V A_{i}\right)\left(\operatorname{Herf}_{i}\right)+\varepsilon_{i},
$$

where $\varepsilon_{i}=v_{i}-\mu_{i}$ is an error term composed of statistical noise, $v_{i} \sim$ iid $N\left(0, \sigma_{v}^{2}\right)$, and the systematic shortfall, $\mu_{i}$. We assume that $\mu_{i}$ is distributed exponentially, $\mu_{i}(>0) \sim \theta \exp (-\theta u) .{ }^{26}$ The results of

this estimation are reported in Appendix A, Table A4.

The best-practice value of a firm's investment opportunities in the markets in which it operates (measured in dollars) is given by this frontier value:

$$
\begin{aligned}
\text { Investment Opportunities }_{i}= & \alpha+\beta\left(B V A_{i}\right)+\gamma\left(B V A_{i}\right)^{2} \\
& +\gamma_{A G}\left(B V A_{i}\right)\left(\text { Growth }_{i}\right)+\gamma_{A H}\left(B V A_{i}\right)\left(\text { Herf }_{i}\right) .
\end{aligned}
$$

This is an estimate of a bank's charter value, which is the value of its charter in a competitive auction. Franchise value, the achieved market value, differs from charter value when agency problems erode market value.

\footnotetext{
${ }^{25}$ We consider only deposits at banking institutions; deposits at thrifts and credit unions are not included in the analysis. Market share measure is calculated at the state level.

${ }^{26}$ The AIC (BIC) and Vuong's test for relative explanatory power favor the exponential distribution of the onesided error term over the half-normal distribution.
} 
To compare the value of investment opportunities of banks of different sizes, we normalize investment opportunities by BVA to obtain:

Investment Opportunity Ratio $_{i}=$ Investment Opportunities $_{i} / B V A_{i}$.

\subsection{Results on Financial Performance}

Table 1 shows the results for the performance measures based on accounting data, and Table 1A provides difference-in-mean tests across the five categories of banks. As shown, there are no statistically significant differences in ROA and risk-normalized ROA (rows 4 and 8) between large community banks and midsize banks, but these banks tend to outperform small community banks. This is a well-known result in the literature. ${ }^{27}$ We add to this result by considering the average noised-adjusted ROA and the best-practice ROA. As shown in rows 5 and 7, noise-adjusted ROA and best-practice ROA increase with size across the five size groups. Moreover, as shown in row 6, the ROA shortfall, the difference between the best-practice and noise-adjusted ROA, is statistically higher at small community banks than at large community banks. As shown in row 8 , when we normalize this best practice by risk, we find that large community banks and midsize banks show better potential performance per unit of risk than small community banks. In summary, these accounting measures of performance agree that large community banks, midsize banks, and usually larger banks outperform small community banks.

These results on performance obtained from 2003 and 2016 data are generally consistent with these 2013 findings. In 2003, large community banks, midsize banks, and usually larger banks obtain, on average, a higher ROA, a higher noise-adjusted ROA, and a higher best-practice ROA except when normalized by risk. In 2016, these same patterns are found; however, the number of small community banks is greatly reduced because of the 2015 change in reporting requirements.

Table 2 shows the market-value performance measures for the 268 publicly traded firms in the 2013 sample. Table 2A provides difference-in-mean tests across the five categories of banks.

${ }^{27}$ See, for example, Amel and Prager (2013) and the FDIC (2012). 
Small community banks exhibit the highest investment opportunity ratio (row 4) but achieve the lowest Tobin's $q$ ratio among the bank size categories (rows 5 and 6). The lower Tobin's $q$ ratio for the publicly traded small community suggests that the capital market, on average, values these banks less than publicly traded large community banks, midsize banks, and larger banks, which is consistent with the lower ROA we found for small community banks. Similar to our results using ROA, we also find that small community banks are less efficient at achieving their potential MVA than large community banks, midsize banks, and larger banks: i.e., on average, their market-value inefficiency ratio is higher (row 7). Moreover, we find that, compared to community banks, midsize banks and larger banks are more efficient at achieving their potential MVA. ${ }^{28}$

Similar findings on performance are obtained from 2003 and 2016 data. In 2003, the publicly traded sample of 346 banks shows that small community banks experience the highest valued investment opportunity ratio but the lowest Tobin's $q$ ratio and the highest market-value inefficiency ratio. As in 2013, they achieve, on average, relatively little of their potential value. In 2016, the small community banks among the 275 publicly traded banks exhibit similar performance. However, there are very few of these small banks because of the change in reporting requirements enacted in 2015.

\section{Explaining Differences in Performance: Are Community Banks Handicapped by Spreading Operating Costs?}

Textbooks frequently cite "spreading the overhead" as an important source of scale economies. To provide some evidence, we examine cost and revenue differences across the bank size categories. As shown in Table 1, while the ratio of total revenue to consolidated assets is not significantly different across size groups (row 3), there are some significant differences in costs. In row 2 of Table 3, the ratio of noninterest expense (the cost of labor, supplies, utilities, and fixed assets) to total revenues - a measure of operating cost per dollar of revenue - at small community

\footnotetext{
${ }^{28}$ The relationship of Tobin's $q$ ratio to the investment opportunity ratio and the market-value inefficiency ratio is discussed at length in Hughes and Mester (2013a), pp. 29-30.
} 
banks is significantly higher than at large community banks and midsize banks, and large community banks have higher average operating costs than midsize banks.

Rows 3, 4, and 5 of Table 3 delve deeper into the expense side and report some components of noninterest expenses, in particular, other noninterest expense, expenses related to premises and fixed assets, and salaries and benefits. Other noninterest expenses include such expenses as those related to data processing, legal, telecommunications, the FDIC assessment, accounting and auditing, and advertising and marketing. ${ }^{29} \mathrm{As}$ a proportion of total revenue, other noninterest expenses at small community banks exceed those at large community banks and midsize banks (row 3). In addition, expenses related to premises and fixed assets as a proportion of total revenue are higher at small community banks than at large community banks and midsize banks. In the case of salaries and benefits as a proportion of total revenue, the average at small community banks exceeds the ratios of all groups of larger banks except those in the range, $\$ 50$ billion to $\$ 250$ billion. These differences between small community banks and larger banks point to some disadvantages of small scale.

These advantages of larger scale in the operating cost ratios are not apparent in the 2003 data; however, the 2016 data confirm the 2013 findings of the advantages of larger scale in spreading operating costs.

These results on operating costs and their components are consistent with findings in the literature of scale economies in banking. However, comparing simple operating expense ratios does not account for differences in the banks' investment strategies, which can affect measures of scale economies. For example, larger banks tend to take more risk, which is costly, so comparisons of operating cost ratios may actually understate scale economies from spreading overhead costs. ${ }^{30}$

\footnotetext{
${ }^{29}$ Reporting the individual categories of other noninterest expenses is required only if the amount exceeds $\$ 25,000$ and 3 percent of total noninterest expense. As a result of this restriction, many banks do not report all categories of the breakdown. Thus, we analyze only the aggregate other noninterest expense, which is reported by all banks in the sample.

${ }^{30}$ Hughes and Mester (2013b, 2015) and Hughes, Mester, and Moon (2001) contend that larger banks, which, on average, take more risk than smaller banks, incur higher costs because of their extra risk taking. These extra costs can obscure the technological scale economies due to better diversification and spreading operating costs over larger output if account is not taken of scale-related endogenous risk taking. Their
} 
To take account of some of these differences across bank size categories, we examine investment strategies, risk taking, and other balance-sheet factors in the next section.

\section{How Do Asset Portfolios Differ by Bank Size?}

Table 4 describes differences in the asset components, asset quality, and off-balance-sheet activities across bank size groups. Table 4A provides difference-in-mean tests across the five categories of banks. While there is no statistically significant difference in the mean ratio of loans to assets or in the share of consumer loans across the two groups of community banks and midsize banks (rows 2 and 6), small community banks hold a significantly higher proportion of real estate assets in their portfolios compared with larger banks (row 3). Both small and large community banks hold a higher proportion of commercial real estate (CRE) loans than larger banks (row 5), which can be riskier than other real estate loans, thus potentially exposing community banks to greater credit risk than larger banks. The mean share of total business loans increases with bank size except at the largest banks, and these differences are statistically significant (row 7).

Some loans included in total business loans are SBLs, which are defined as business loans with an initial principal balance of less than $\$ 1$ million. While there is no statistically significant difference in the proportion of SBLs in the portfolios of small and large community banks, these community banks hold a significantly higher proportion of SBLs than midsize banks, large banks, and the largest banks (row 8). This is consistent with the statistics reported by Jagtiani and Lemieux $(2016,2018)$, although they also report that the gap in the ratio of SBLs to assets between midsize banks and community banks has become narrower over the years.

investigations show that the scale economies predicted by textbooks often elude the standard approach to estimating scale economies for this reason. Hughes, Mester, and Moon (2001) find that the estimated scale economies index of the standard approach increases with better diversification but decreases with a variety of measures of risk taking. Kovner, Vickery, and Zhou (2014) also demonstrate that finding evidence of operating cost economies depends on controlling for the investment strategy. Without controlling for investment strategy, they find that a 10 percent increase in assets implies a 9.93 percent increase in operating costs, essentially constant returns to scale. When the authors control for asset allocation, the cost elasticity drops to 9.79 percent, and when they control for asset allocation, revenue sources, funding structure, and organizational complexity, the ratio drops further to 8.99 percent, essentially operating cost economies. They find a pattern that implies that operating scale economies increase with bank size and that the largest financial institutions obtain the largest operating cost economies. 
We find no significant difference in the share of liquid assets across all size categories except the largest banks, which hold a significantly higher proportion of liquid assets (row 9). Liquidity is also affected by other activities not recorded as assets on the balance sheet. We use the ratio of noninterest income to total revenue as a proxy for off-balance-sheet activities. Small community banks engage in a lower share of off-balance-sheet activities than large community banks, midsize banks, large banks, and larger banks (row 10). In terms of loan quality, we find that the ratio of nonperforming loans to assets is significantly higher at small community banks than at the other categories of larger banks (row 11). ${ }^{31}$

How banks price their loans also differs by bank size. The average contractual interest rate on loans declines with larger bank size (row 12). Small community banks' higher loan rate and their higher proportion of nonperforming loans may reflect higher loan risk (perhaps from their higher share of CRE and SBL lending). However, their higher nonperforming loan ratio raises the question of the degree to which they lend to riskier borrowers and the degree to which their credit analysis and loan monitoring may be less effective. We turn to this question in the next section.

\section{Decomposing Loan Nonperformance into Inherent Credit Risk and Lending Inefficiency}

We apply a technique developed by Hughes and Moon (2017) to distinguish nonperformance because of less effective credit evaluation and loan monitoring from nonperformance because of the bank's choice of the inherent credit risk of its loan portfolio. We focus on two types of loans: business loans and CRE loans. We use a stochastic frontier technique to estimate a bank's best-practice (i.e., minimum) ratio of nonperforming business loans to total business loans and best-practice ratio of nonperforming CRE loans to total CRE loans, controlling for the share of the amount held of this type of loan, the total loan volume, the average contractual

\footnotetext{
${ }^{31}$ Asset quality is measured by the sum of three components: (1) the amount of loans that are nonperforming, (2) the amount of loans that have been charged off, and, in the case of real estate loans, (3) the amount of foreclosed real estate owned by the bank. Because banks differ in the aggressiveness with which they charge off nonperforming loans, our measure of nonperforming loans includes the amount of gross charge-offs in order to eliminate any bias caused by different charge-off strategies among banks.
} 
interest rate charged for this type of loan, and the market concentration and 10-year average GDP growth rate in the markets in which the bank operates. The minimum ratio represents the bestobserved-practice nonperformance controlling for the loan volume and other factors that, as such, capture inherent credit risk. It indicates the lowest nonperforming loan ratio the bank could achieve if it were fully efficient at credit-risk evaluation and loan monitoring. The difference between a bank's achieved nonperforming loan ratio adjusted for noise and its best-observedpractice ratio - its excess nonperforming loan ratio - gauges its efficiency at credit analysis and loan monitoring. Appendix B describes the details of the estimation and the fitted frontiers.

As shown in Table 5, the mean ratio of business loans to total loans increases with bank size (row 2), and the average contractual interest rate on business loans declines with bank size (row 3). Small community banks experience the highest nonperforming proportion of business loans (row 4). The largest banks and large banks experience the lowest nonperforming business loan ratio.

Decomposing the nonperforming business loan ratio into the best practice, the excess over the best practice, and the noise, we find that the best-practice nonperforming loans ratio, gauging inherent credit risk, increases with bank size, and the excess ratio, measuring lending inefficiency, decreases with bank size (rows 5 and 6). These results suggest that smaller banks tend to lend to less risky business borrowers, but they are less efficient at credit evaluation and monitoring, so they experience higher rates of nonperformance. Larger banks experience lower rates of nonperformance even though they lend to riskier business borrowers; hence, their lower nonperformance results from greater efficiency at lending.

Table 6 reports the comparable results for CRE loans. The mean share of CRE loans to total loans decreases with bank size (row 2), and the average contractual interest rate on CRE loans declines with bank size (row 3). The share of nonperforming CRE loans to CRE loans is higher for small community banks than for large community banks, midsize banks, large banks, and the largest banks (row 4). 
The decomposition shows that the best-practice nonperforming loan ratio for CRE loans is slightly lower at large community banks but otherwise similar across size groups (row 5). The average excess nonperforming loan ratio, though, is significantly higher at small community banks than at the groups of larger banks (row 6). These results suggest that the comparatively high nonperforming CRE loan ratio at small community banks results from less efficiency at credit evaluation and loan monitoring and not from lending to more risky borrowers.

Thus, both CRE and business loans exhibit the same qualitative patterns of nonperformance and lending inefficiency. Small community banks exhibit the highest rate of nonperformance for both types of loans. While they have the lowest inherent credit risk for business loans, they exhibit the highest lending inefficiency for both CRE and business loans, resulting in their higher rates of nonperformance. This is consistent with their charging higher contractual loan rates.

In the 2016 data, small community banks exhibit the lowest inherent credit risk both of CRE loans and of business loans but the highest rate of loan nonperformance for both types of loans, which results from the highest rate of inefficiency in both types of lending. While these patterns are consistent with those in the 2013 data, the difference in the rate of nonperformance for both types of loans is not statistically significant. On the other hand, the inherent credit risk assumed in both business and CRE loans is statistically lower for community banks than for larger banks, which implies that larger banks are more efficient in making CRE and business loans. In 2003 small community banks show the second highest rate of business loan nonperformance for the lowest inherent credit risk, which results in the highest degree of lending inefficiency. In contrast, the largest banks show the highest rate of nonperformance, which results from the high inherent credit risk rather than from lending inefficiency. We cannot estimate the CRE loan frontier because the average contractual interest rate, an important variable in the specification of the stochastic frontier, cannot be computed. The 2003 Call Reports provided interest income for the aggregate category, real estate loans, but not for its breakdown into commercial and residential real estate. 


\section{Does Scale Affect the Financial Incentives to Lend to Small Businesses?}

Given the relative performance across size categories, we explore whether a scale-related improvement in financial performance gives small community banks an incentive to become larger, and if so, whether they have an incentive to reduce the share of small business lending in their portfolios to be comparable with that of larger banks.

We regress the four financial performance measures - the risk-normalized ROA, the ROA shortfall, Tobin's $q$ ratio, and market-value inefficiency - on the loan-to-asset ratio, the composition of lending activities, the $\ln$ (total assets), the investment opportunity ratio, asset quality, and the composition of funding (the deposit ratio and the capital ratio). ${ }^{32}$ Table 7 and Table 8 present the results for the accounting-based measures of performance and the market-value-based measures, respectively.

The performance equations are given by:

$$
\begin{aligned}
P_{i}=a_{0} & +a_{1} \text { Total loans/Assets }+a_{2} \text { Total business loans/Assets } \\
& +a_{3} \text { Small business loans/Assets }+\boldsymbol{X} \boldsymbol{\beta}+\varepsilon_{\mathrm{i}} .
\end{aligned}
$$

where $P_{i}=$ Performance, as measured by the risk-normalized ROA, the ROA shortfall, Tobin's $q$ ratio, and market-value inefficiency, and the control factors in $\boldsymbol{X}$ include: Residential real estate loans/Assets, Commerical real estate loans/Assets, Consumer loans/Assets, Liquid assets/Assets, Investment opportunity ratio (for the market-value-based regressions), $\ln$ (Book value of assets in \$1000s), Noninterest income/Total revenue, Nonperforming loans/Assets, Deposits/(Deposits + Other borrowed funds), and (Equity + Subordinated debt + Loan loss reserves)/Assets.

By controlling for the ratio of total loans to assets, a variation in any category of loans in the regression, except SBLs, implies an equivalent change in the categories of loans omitted from the

\footnotetext{
32 Because the performance measures are based on market values, we control for investment opportunities in these regressions. In Table 8, there is evidence that the investment opportunity ratio is positively related to financial performance for small community banks and negatively related to performance for large community banks. Hughes and Mester (2013a) find that, controlling for asset size, more valuable investment opportunities that are associated with poorer financial performance are evidence of agency problems, a point that is beyond the scope of this investigation.
} 
regression. These omitted categories include leases, agricultural loans, loans to nondepository institutions, and other loans.

Small business loans constitute part of total business loans. Total business loans are the sum of SBLs (i.e., business loans with origination of less than $\$ 1$ million) and large business loans (i.e., business loans with origination of greater than $\$ 1$ million). Thus, a 1 percent increase in the ratio of SBLs to assets (an increase measured in terms of the volume of assets), holding constant the ratio of total business loans to assets, implies a 1 percent decrease (measured in terms of the volume of assets) in the ratio of large business loans to assets. Based on Equation (24), the change in financial performance associated with such a change would be $a_{3} \times 0.01$. Of course, the ratio of total loans to assets is also held constant, so the variation affects only the composition of total business loans.

On the other hand, a change in the ratio of total business loans to assets (measured in terms of the volume of assets) holding constant the ratio of SBLs to assets implies an equivalent change in the ratio of large business loans to assets. Holding the ratio of total loans to assets constant, based on Equation (24),

$$
\Delta P_{i}=\mathrm{a}_{2} \times \Delta \text { Total business loans } / \text { Assets. }
$$

For example, the change in performance associated with a 1 percent increase in the ratio of total business loans to assets $=\boldsymbol{a}_{2} \times 0.01$. Because we are holding constant the ratio of SBLs to assets in this calculation, this 1 percent increase in the ratio of total business loans to assets is a 1 percent increase in the ratio of large business loans to assets. And because we are holding the ratio of total loans to assets constant, this 1 percent increase in the ratio of business loans to assets implies an equivalent change in the omitted categories of loans.

If, instead, a 1 percent increase in total business loans to assets is accompanied by a 1 percent increase in the ratio of SBLs to assets, the ratio of large business loans to assets would remain constant, and the change in performance associated with such a change would be $\left(a_{2}+a_{3}\right) \times$ 
0.01. Holding the ratio of total loans to assets constant, such an increase implies an equivalent change in other categories of loans omitted from the regression.

A 1 percent increase in the ratio of total business lending to assets accompanied by a 1 percent increase in the ratio of total loans to assets represents an increase in overall lending effected by large business lending; the resulting change in performance is given by $\left(a_{1}+a_{2}\right) \times 0.01$. If the ratio of SBLs to assets is simultaneously increased by 1 percent, the change in performance is given by $\left(a_{1}+a_{2}+a_{3}\right) \times 0.01$. In the latter case, the ratio of large business loans to assets would remain constant.

The results using accounting measures of performance, in Table 7, point to the negative impact of nonperforming loans on financial performance at all but the largest banks, an impact whose magnitude increases with bank size. The proportion of loans to assets is positively associated with performance both at small and large community banks. A marginal increase in the proportion of SBLs to assets, holding total business loans to assets constant, implies a corresponding decrease in the large business loan ratio. This particular increase in SBLs is associated with improved accounting performance at small and large community banks. The last rows of Table 7 report simultaneous variations in these components. Notably, a 1 percent increase in total loans and in business loans, holding SBLs constant, as well as a 1 percent increase in total loans, total business loans, and SBLs, is associated with improved accounting performance at small and large community banks.

The accounting measures of performance do not account for the market's valuation of expected future performance or of the rate at which expected future performance is discounted. As indicated in Table 8, market-value performance is, on average, negatively associated with the nonperforming loan ratio at all but the largest banks. In addition, there is evidence that small community banks have a financial incentive to decrease SBLs. To see this, note that a 1 percent decrease in the ratio of SBLs to assets, holding constant total business loans to assets (which implies a 1 percent increase in large business loans to assets), is associated with a statistically significant 
increase in Tobin's $q$ ratio of $(-0.01) \times(-0.260)=+0.0026=0.26$ percent. In contrast, an increase in SBLs of the same magnitude at large community banks is associated with an increase of 0.36 percent in Tobin's $q$ ratio. If a 1 percent increase in the ratio of total business loans to assets at small community banks is combined with a 1 percent increase in the ratio of total loans to assets and a 1 percent decrease in the SBL ratio, Tobin's $q$ ratio increases by $[(+0.01)(0.210)]$ $+[(+0.01)(0.207)]+[(-0.01)(-0.260)]=0.00677$, or 0.677 percent, which is significantly different from zero (with a $p$ value of 0.027 ). Thus, at small community banks a 1 percent decrease in the SBL ratio, combined with a 1 percent increase in total business lending and in the ratio of total loans to assets, which implies a 2 percent increase in large business loans, is associated with a statistically significant increase in market value measured by the $q$ ratio. Moreover, the average market-value inefficiency of small community banks is positively associated with this reduction in SBLs. Overall, we find that the capital market provides small community banks a financial incentive to reduce their SBL activities and to increase their lending to larger businesses.

Unlike in the case of small community banks, we find that the capital market provides a financial incentive for large community banks to increase small business lending. For large community banks, a 1 percent increase in the SBL ratio is associated with a statistically significant +0.00360 , or 0.360 percent, increase in Tobin's $q$ ratio. This increase holds total business lending constant and, hence, implies a reduction in large business lending. In addition, a 1 percent decrease in the total business loan ratio, holding the SBL ratio constant, is associated with a statistically significant +0.00251 , or 0.251 percent, increase in Tobin's $q$. A simultaneous decrease of 1 percent in the total business loan ratio and a 1 percent increase in the SBL ratio would result in a statistically significant increase of 0.612 percent in Tobin's $q$ ratio (with $p$ value of 0.002 ). This portfolio adjustment would also imply a decrease of -0.290 percent in the market-value inefficiency ratio. If this simultaneous portfolio adjustment is combined with a 1 percent decrease in the ratio of total loans to assets, the associated statistically significant increase in Tobin's $q$ ratio is 0.702 
percent and the statistically significant decrease in the market-value inefficiency ratio is -0.300 percent.

Finally, we find that midsize banks (with assets of more than $\$ 10$ billion) may have an incentive to reduce the proportion of their assets devoted to business lending in general and small business lending in particular. Although neither the coefficient, -0.046 , on the total business loan ratio nor the coefficient, -0.166 , on the SBL ratio is statistically significant, a 1 percent decrease in both ratios, combined with a 1 percent decrease in the ratio of total loans to assets, is associated with a statistically significant increase of 0.00374 , or 0.374 percent, in Tobin's $q$ ratio and a statistically significant decrease of -0.270 percent in the market-value inefficiency ratio.

The 2016 data provide similar evidence that, at the margin, the capital market penalizes small business lending by small community banks and rewards it at large community banks. The evidence provided by Tobin's $q$ ratio is consistent with that of the market-value inefficiency ratio. The 2003 data give weak evidence that, on average, Tobin's $q$ ratio is negatively related to small business lending at small community banks. On the other hand, the 2003 data provide strong evidence that Tobin's $q$ ratio is negatively related to small business lending and positively related to market-value inefficiency at large banks (with assets greater than $\$ 50$ billion in 2013 dollars).

\section{Conclusions}

This paper uses 2013 data to investigate performance and operational efficiencies and confirms the robustness of the 2013 findings with data drawn from 2003 and 2016. While we consider banks of all sizes, we focus on banks with assets of less than $\$ 50$ billion. The business models of these smaller banks differ considerably from the models of larger banks. We find that better financial performance is associated with larger asset size. On average, large community banks (banks with assets between $\$ 1$ billion and $\$ 10$ billion) exhibit better accounting-based and market-value-based financial performance than small community banks (banks with assets under $\$ 1$ billion). We also find that, on average, compared to small community banks, large community banks, midsize banks (banks with assets between $\$ 10$ billion and $\$ 50$ billion), large banks (banks 
with assets between $\$ 50$ billion and $\$ 250$ billion), and the largest banks (banks with assets greater than $\$ 250$ billion) have less valuable investment opportunities but achieve higher proportions of their potential market value and ROA. In short, they are more efficient. This finding suggests that the better performance is associated with better management of the relatively less valuable investment opportunities.

The better efficiency of larger banks compared with small community banks extends as well to business lending and commercial real estate lending. Compared with small community banks, large community banks, midsize banks, and larger banks assume higher inherent credit risk and exhibit more efficient lending.

If such a scale-related improvement in financial performance provides an incentive for smaller banks to grow in size, an important question is whether this might also provide community banks with an incentive to reduce the proportion of their assets allocated to small business loans (SBLs) as they grow in size to achieve scale economies. We find no evidence in support of this hypothesis. There is a statistically significant positive relationship between financial performance and the ratio of SBLs to assets at large community banks, suggesting they would have financial incentives to increase their SBL share as they become larger. ${ }^{33}$

However, our estimates of the contribution of total business lending and SBL to financial performance for publicly traded banks suggest that small community banks have financial incentives to shift their lending from small businesses to larger businesses, while large community banks have a financial incentive to increase lending to small businesses. The case is different for midsize banks, where we find that performance is positively related to a proportional decrease in total business lending and SBLs. This finding suggests that midsize banks have financial incentives to reduce their asset shares in overall business loans and in loans to small businesses.

\footnotetext{
33 This finding is consistent with the results of Jagtiani, Kotlier, and Maingi (2015), who find that there were no adverse impacts on the overall lending to small businesses when small community banks grew larger as they became part of a larger acquiring bank. In fact, the combined banking firms increased their lending to small businesses more when the acquirers were large banks.
} 
In short, our evidence shows that, on average, large community banks outperform small community banks. This may reflect that the costs of regulatory compliance and technology both have a fixed-cost component, which results in there being a size below which the costs outweigh any lending advantages a small community bank might have. The positive relationship between the better financial performance of large community banks and their SBL activities suggests that SBLs are an important component of large community banks' portfolios. Therefore, the concern that as small community banks become larger, they might become less effective at lending to small businesses and reduce the proportion of assets devoted to SBLs, thereby adversely affecting small businesses' access to credit, is not supported by the results in this paper. 


\section{References}

Amel, Dean F., and Robin A. Prager (2013). "Performance of Community Banks in Good Times and Bad Times: Does Management Matter?” Board of Governors of the Federal Reserve System.

Baele, Lieven, Oliver De Jonghe, and Rudi Vander Vennet (2007). "Does the Stock Market Value Bank Diversification?” Journal of Banking and Finance 31, 1999-2023.

Bauer, Paul W. (1990). "Recent Developments in the Econometric Estimation of Frontiers," Journal of Econometrics 46, 39-56.

Beccalli, Elena, Mario Anolli, and Giuliana Borello (2015). “Are European Banks Too Big? Evidence on Economies of Scale," Journal of Banking and Finance 58, 232-246.

Beccalli, Elena, and Pascal Frantz (2013). “The Determinants of Mergers and Acquisitions in Banking," Journal of Financial Services Research 43 (3), 265-291.

Berger, Allen, Geraldo Cerqueiro, and María Fabiana Penas (2014). “Market Size Structure and Small Business Lending: Are Crisis Times Different from Normal Times?" Review of Finance, $1-31$.

Berger, Allen, Adrian Cowan, and Scott Frame (2011). "The Surprising Use of Credit Scoring in Small Business Lending by Community Banks and the Attendant Effects on Credit Availability, Risk, and Profitability," Journal of Financial Services Research 39, 1-17.

Berger, Allen, Scott Frame, and Nathan Miller (2005). "Credit Scoring and the Availability, Price, and Risk of Small Business Credit,” Journal of Money, Credit, and Banking 37, 191-222.

Berger, Allen, William Goulding, and Tara Rice (2014). "Do Small Businesses Still Prefer Community Banks?” Journal of Banking and Finance 44, 264-278.

Berger, Allen, Nathan Miller, Mitchell Petersen, Raghuram Rajan, and Jeremy Stein (2005). “Does Function Follow Organizational Form? Evidence from the Lending Practice of Large and Small Banks," Journal of Financial Economics 76 (2), 237-269.

Berger, Allen, and Gregory Udell (2006). "A More Complete Conceptual Framework for SME Finance," Journal of Banking and Finance 30, 2945-2966.

Chakraborty, Atreya, and Charles Hu (2006). "Lending Relationships in Line-of-Credit and Nonlineof-Credit Loans: Evidence from Collateral Use in Small Business," Journal of Financial Intermediation 15, 86-107.

De Jonghe, Oliver, and Rudi Vander Vennet (2005). “Competition Versus Agency Costs: An Analysis of Charter Values in European Banking," Ghent University Working Paper.

DeYoung, Robert, Scott Frame, Dennis Glennon, Daniel McMillen, and Peter Nigro (2008). "Commercial Lending Distance and Historically Underserved Areas," Journal of Economics and Business 60, 149-164.

DeYoung, Robert, Scott Frame, Dennis Glennon, and Peter Nigro (2011). "The Information Revolution and Small Business Lending: The Missing Evidence," Journal of Financial Services Research 39 (1), 19-33. 
DeYoung, Robert, Dennis Glennon, and Peter Nigro (2008). "Borrower-Lender Distance, Credit Scoring, and Loan Performance: Evidence from Informational-Opaque Small Business Borrowers," Journal of Financial Intermediation 17 (1), 113-143.

Dijkstra, M.A. (2017). Economies of Scale and Scope in Banking: Effects of Government Intervention, Corporate Strategy and Market Power, Amsterdam University Press.

Federal Deposit Insurance Corporation (2012), FDIC Community Banking Study.

Feng, G. and A. Serletis (2010). "Efficiency, Technical Change, and Returns to Scale in Large US Banks: Panel Data Evidence from an Output Distance Function Satisfying Theoretical Regularity," Journal of Banking and Finance 34, 127-138.

Habib, Michel A., and Alexander Ljungqvist (2005). "Firm Value and Managerial Incentives: A Stochastic Frontier Approach," Journal of Business 78, 2053-2093.

Hughes, J.P., Lang, W., Moon C.-G. and Pagano, M. (1997). "Measuring the Efficiency of Capital Allocation in Commercial Banking,” Working Paper 98-2, Federal Reserve Bank of Philadelphia (revised as Working Paper 2004-1, Rutgers University Economics Department).

Hughes, Joseph P., William Lang, Loretta J. Mester, and Choon-Geol Moon (1999). "The Dollars and Sense of Bank Consolidation," Journal of Banking and Finance 23, 291-324.

Hughes, Joseph P., William Lang, Loretta J. Mester, Choon-Geol Moon, and Michael Pagano (2003). "Do Bankers Sacrifice Value to Build Empires? Managerial Incentives, Industry Consolidation, and Financial Performance," Journal of Banking and Finance 27, 417-447.

Hughes, Joseph P., and Loretta J. Mester (2010). "Efficiency in Banking: Theory, Practice, and Evidence," in Allen N. Berger, Philip Molyneux, and John Wilson, eds., The Oxford Handbook of Banking, Oxford, U.K.: Oxford University Press, 463-485.

Hughes, Joseph P., and Loretta J. Mester (2013a). "A Primer on Market Discipline and Governance of Financial Institutions for Those in a State of Shocked Disbelief," in Fotios Pasiouras, ed., Efficiency and Productivity Growth in the Financial Services Industry, Chichester, U.K.: John Wiley and Sons, 19-47.

Hughes, Joseph P., and Loretta J. Mester (2013b). “Who Said Large Banks Don't Experience Scale Economies? Evidence from a Risk-Return-Driven Cost Function," Journal of Financial Intermediation 22 (4), 559-585.

Hughes, Joseph P., and Loretta J. Mester (2015). "Measuring the Performance of Banks: Theory, Practice, Evidence, and Some Policy Implications," in Allen N. Berger, Philip Molyneux, and John Wilson, eds., The Oxford Handbook of Banking, second edition, Oxford, U.K.: Oxford University Press, 247-270.

Hughes, Joseph P., and Loretta J. Mester (forthcoming). "The Performance of Financial Institutions: Modeling, Evidence, and Some Policy Implications," in Allen N. Berger, Philip Molyneux, and John Wilson, eds., The Oxford Handbook of Banking, second edition, Oxford, U.K.: Oxford University Press. 
Hughes, Joseph P., Loretta J. Mester, and Choon-Geol Moon (2001). “Are Scale Economies in Banking Elusive or Illusive? Incorporating Capital Structure and Risk into Models of Bank Production," Journal of Banking and Finance 25 (12), 2169-2208.

Hughes, Joseph P., and Choon-Geol Moon (2003). “Estimating Managers' Utility Maximizing Demand for Agency Goods," Rutgers University, Working Paper 2003-24.

Hughes, Joseph P., and Choon-Geol Moon (2017). "How Bad Is a Bad Loan? Distinguishing Inherent Credit Risk from Inefficient Lending (Does the Capital Market Price This Difference?)," Department of Economics, Rutgers University Working Paper.

Jagtiani, Julapa, Ian Kotliar, and Raman Quinn Maingi (2016). “Community Bank Mergers and the Impact on Small Business Lending," Journal of Financial Stability 27 (11), 106-121.

Jagtiani, Julapa, and Cathy Lemieux (2016). “Small Business Lending After the Financial Crisis: a New Competitive Landscape for Community Banks," Economic Perspectives, Federal Reserve Bank of Chicago, Number 3.

Jagtiani, Julapa, and Cathy Lemieux (2018). "The Roles of Alternative Data and Machine Learning in Fintech Lending: Evidence from the LendingClub Consumer Platform," Federal Reserve Bank of Philadelphia Working Paper, presented at the American Economic Association conference, January 6, 2018.

Jondrow, James, C. A. Knox Lovell, Ivan S. Materov, and Peter Schmidt (1982). "On the Estimation of Technical Efficiency in the Stochastic Frontier Production Function Model," Journal of Econometrics 19, 233-238.

Kovner, Anna, James Vickery, and L. Zhou (2014). “Do Big Banks Have Lower Operating Costs?” Economic Policy Review, Federal Reserve Bank of New York (December) 1-27.

Kowalik, Michal (2014). “Can Small Banks Survive Competition from Large Banks?” Federal Reserve Bank of Boston, Working Paper.

Mester, Loretta, J. (1999). “Banking Industry Consolidation: What's a Small Business to Do?” Federal Reserve Bank of Philadelphia Business Review (January/February), 3-16.

Mester, Loretta J., Leonard Nakamura, and Micheline Renault (2007). "Transaction Accounts and Loan Monitoring," Review of Financial Studies 20, 529-556.

Morgan, Donald P., and Adam B. Ashcraft (2003). "Using Loan Rates to Measure and Regulate Bank Risk: Findings and an Immodest Proposal," Journal of Financial Services Research 24:2/3, 181-200.

Petersen, Mitchell A., and Raghuram G. Rajan (1995). "The Effect of Credit Market Competition on Lending Relationships," Quarterly Journal of Economics 110 (2), 407-443.

Petersen, Mitchell A., and Raghuram G. Rajan (2002). “Does Distance Still Matter? The Information Revolution in Small Business Lending," Journal of Finance 57, 2533-2570.

Prager, Robin, and John Wolken (2008). "The Evolving Relationship between Community Banks and Small Businesses: Evidence from the Surveys of Small Business Finances," Finance and Economics Discussion Series Working Paper 2008-60. 
Stiroh, Kevin J., and Adrienne Rumble (2006). "The Dark Side of Diversification: The Case of US Financial Holding Companies," Journal of Banking and Finance 30, 2131-2161.

Wheelock, D. and Wilson, P. (2012). "Do Large Banks Have Lower Costs? New Estimates of Returns to Scale for US Banks," Journal of Money, Credit, and Banking 44, 171-99. 


\section{Figure 1 \\ Best-Observed-Practice Return on Assets}

This figure illustrates the upper envelope of best-observed-practice ROA that is obtained by stochastic frontier estimation of the quadratic relationship between the ROA and the standard deviation of ROA (ROASTD). The error term, $\varepsilon_{i}=v_{i}-\mu_{i}$, is a composite term used to distinguish two-sided statistical noise, $v_{i} \sim$ iid $N\left(0, \sigma_{v}^{2}\right)$, from the one-sided systematic shortfall from bank $i^{\prime} \mathrm{s}$ best-observed-practice ROA. We assume $\mu_{\mathrm{i}}$ is distributed exponentially, $\mu_{i}(>0) \sim \theta \exp (-\theta u)$. The quadratic specification allows the upper envelope to be nonlinear.

In this example, bank $i$ achieves an ROA of 1.08 percent and its ROA adjusted for noise is $\mathrm{ROA}_{\mathrm{i}}-v_{\mathrm{i}}=$ $1.08-(-0.02)=1.10$ percent. Bank $i$ 's best-practice ROA is 1.70 percent. So its ROA shortfall from best-practice is 0.60 percentage point $(=1.70-1.10)$. The standard deviation of its ROA is 2.22 , so its risk-normalized best-practice ROA is $0.76(=1.70 / 2.22)$ and its risk-normalized ROA shortfall is $0.27(=0.60 / 2.22)$.

Return on Assets (ROA)

(percent)

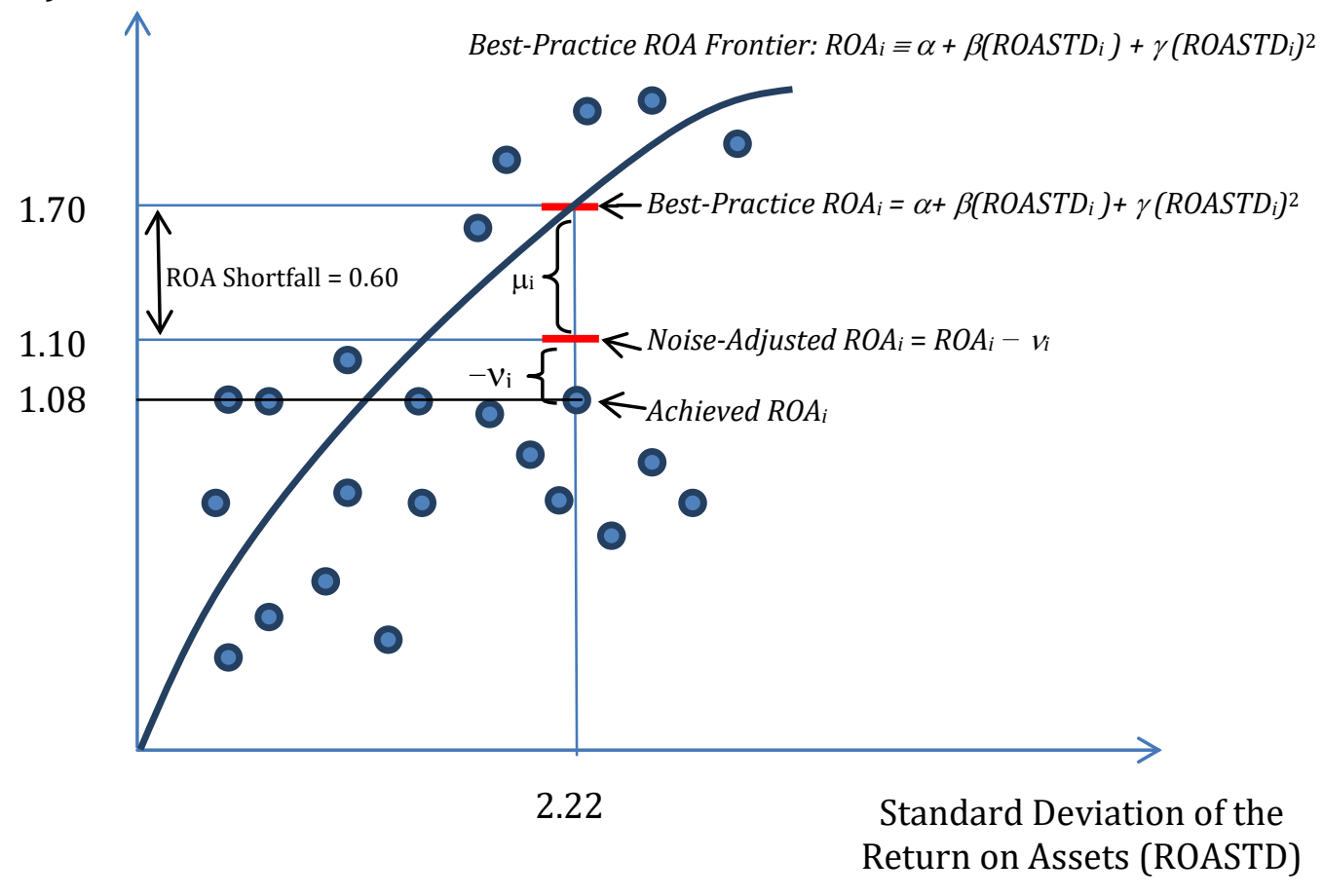


Figure 2

Market-Value Frontier

This figure illustrates the potential-value frontier that is obtained by stochastic frontier estimation of the quadratic relationship between the market value of assets (MVA) and the book value of assets net of goodwill (BVA). The error term, $\varepsilon_{i}=v_{i}-\mu_{i}$, is a composite term used to distinguish statistical noise, $v_{i} \sim$ iid $N\left(0, \sigma_{v}^{2}\right)$, from the systematic shortfall from bank $i$ 's highest potential (frontier) market value. We assume $\mu_{i}$ is distributed exponentially, $\mu_{i}(>0) \sim \theta \exp (-\theta u)$. The quadratic specification allows the frontier to be nonlinear. The potential-value frontier is the deterministic kernel of the estimated quadratic relationship.

In this example, bank $i$ has invested 100 in assets (i.e., $\mathrm{BVA}_{\mathrm{i}}=100$ ) and it achieves an MVA of 106. Its MVA adjusted for noise is $\mathrm{MVA}_{\mathrm{i}}-v_{\mathrm{i}}=106-(-2)=108$. Bank $i$ 's best-practice MVA is 120 . So its MVA shortfall from best-practice value is 12 percentage points $=(120-108)$. Its market-value inefficiency ratio is $0.10(=12 / 120)$, and its noise-adjusted Tobin's $q$ ratio is $1.08(=108 / 100)$.

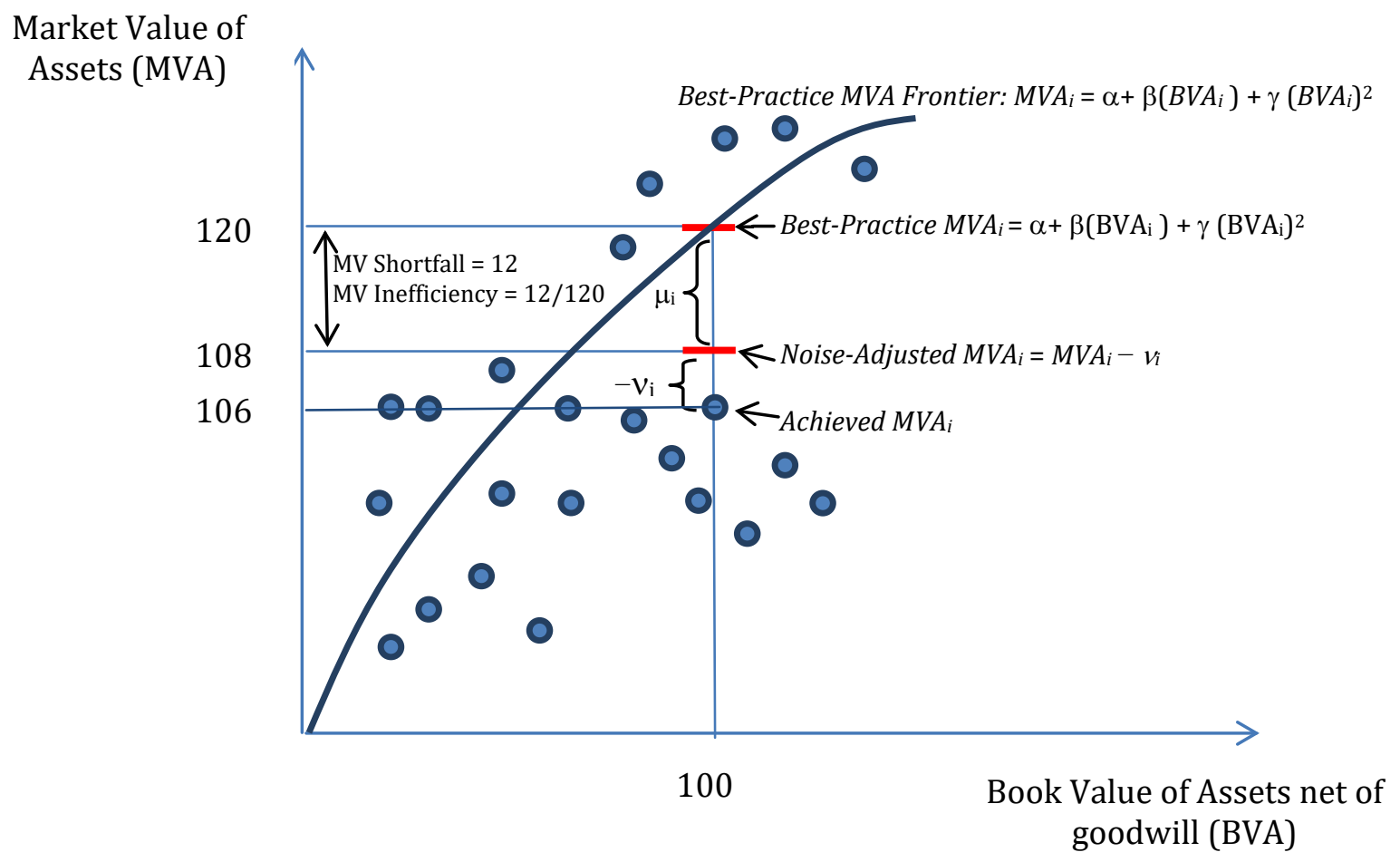




\section{Table 1 \\ Financial Performance - 2013 \\ Sample Partitioned by Size Groups Based on Consolidated Assets}

The data set includes 761 top-tier bank holding companies at the end of 2013. Small community banks have consolidated assets less than $\$ 1$ billion, large community banks have consolidated assets from $\$ 1$ billion up to $\$ 10$ billion, and midsize banks have assets between $\$ 10$ billion and $\$ 50$ billion. To illustrate the differences between these banks and larger banks, we include in the table large banks with assets between $\$ 50$ billion and $\$ 250$ billion and the largest banks with assets exceeding $\$ 250$ billion.

The best-practice ROA is measured by the value of ROA on the estimated best-practice frontier, Equation (2), and the risk-normalized, best-practice ROA is measured by the ratio of best-practice ROA to the standard deviation of ROA, Equation (8). The ROA shortfall, Equation (7), is given by the difference between the best-practice ROA and the noiseadjusted ROA, Equation (6).

For each size category in lines 5-10, the first column reports the values derived from the frontier (Equation 1) that controls for risk, risk squared, and these terms interacted with total assets. The second column reports values from the frontier (Equation 10) that controls for the investment strategy: the ratios of loans to assets, liquid assets to assets, deposits to total borrowed funds, equity capital to assets, and noninterest income to total revenue.

Table 1A provides two-sample $t$ tests for equal means of pairs of size groups.

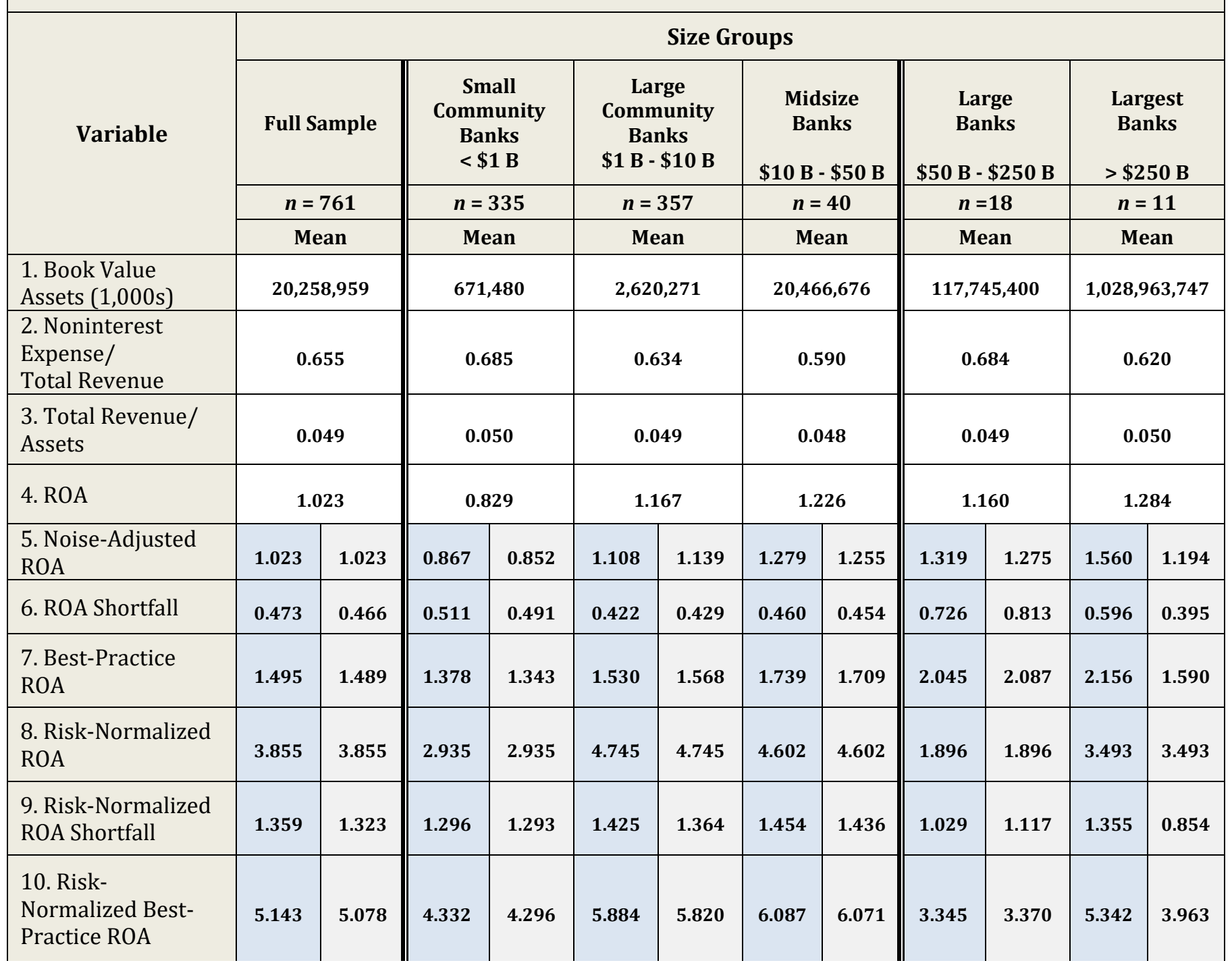


Table 1A: Two-Sample t Tests for Equal Means of Two Size Groups: Year 2013 statistical significance at $10 \%$ : not significant significant number in each box $=$ mean(size group in $\mathrm{y}$-axis) - mean(size group in $\mathrm{x}$-axis )

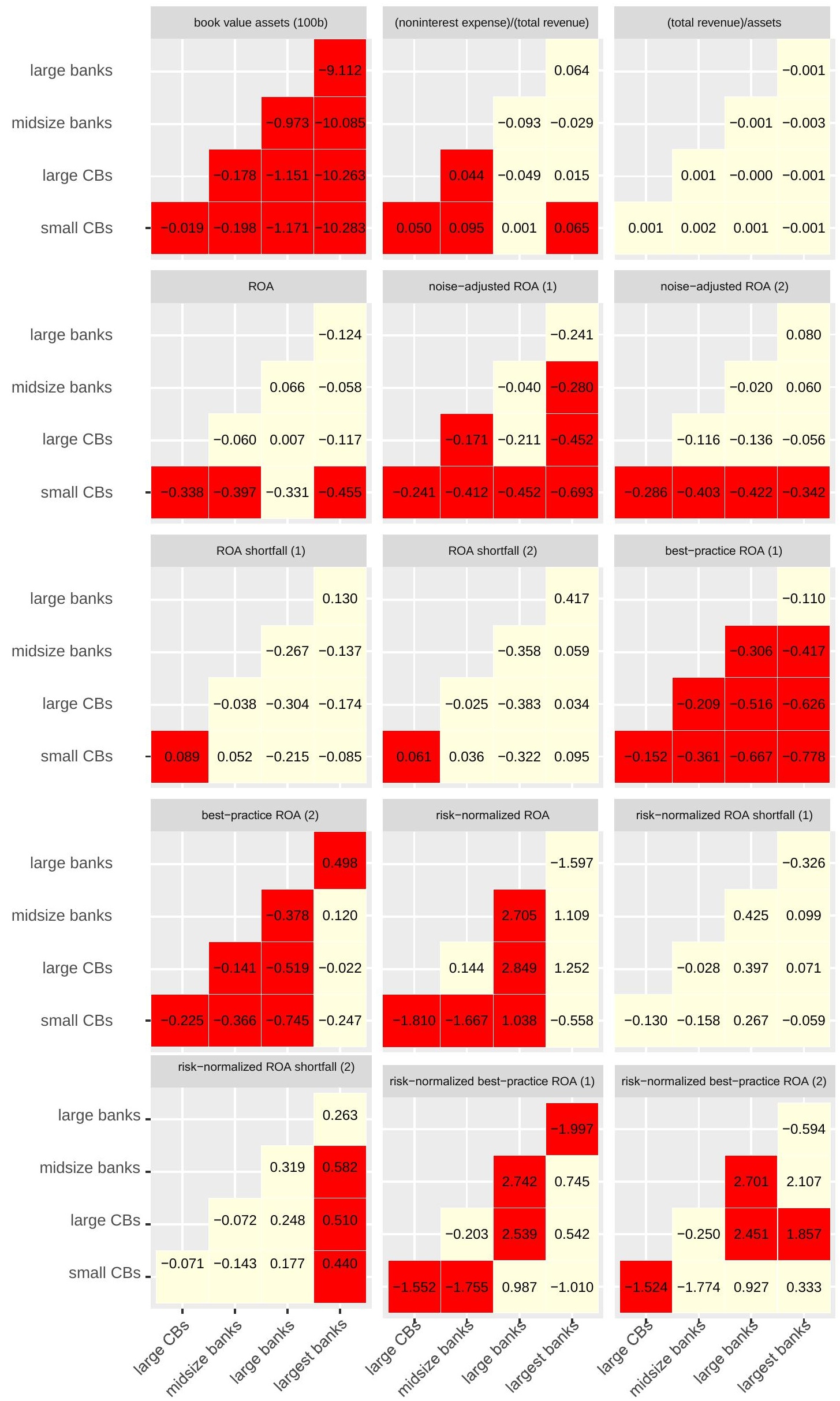




\section{Table 2}

\section{Financial Performance of Publicly Traded Bank Holding Companies Sample Partitioned by Size Groups Based on Consolidated Assets}

The data set includes 268 publicly traded top-tier bank holding companies at the end of 2013. Small community banks have consolidated assets less than $\$ 1$ billion, large community banks have consolidated assets from $\$ 1$ billion up to $\$ 10$ billion, and midsize banks have assets between $\$ 10$ billion and $\$ 50$ billion. To illustrate the differences between these banks and larger banks, we include in the table large banks with assets between $\$ 50$ billion and $\$ 250$ billion and the largest banks with assets exceeding $\$ 250$ billion.

The investment opportunity ratio, Equation (23), is given by the ratio of the highest potential value of assets in the markets in which the bank operates, Equation (22), to the book value of assets net of goodwill. Tobin's q ratio is proxied by the sum of the market value of equity and the book-value of liabilities divided by the book value of assets net of goodwill. The noise-adjusted Tobin's q ratio is given by Equation (20). The market-value inefficiency ratio is the difference between the highest potential market value of assets and the noiseadjusted achieved market value of assets divided by the highest potential value of assets, Equation (19).

Table 2A provides two-sample $t$ tests for equal means of pairs of size groups.

\begin{tabular}{|c|c|c|c|c|c|c|}
\hline \multirow{4}{*}{ Variable } & \multicolumn{6}{|c|}{ Size Groups } \\
\hline & Full Sample & $\begin{array}{c}\text { Small Community } \\
\text { Banks } \\
<\$ 1 \text { B }\end{array}$ & $\begin{array}{c}\text { Large } \\
\text { Community } \\
\text { Banks } \\
\text { \$1 B - \$10 B }\end{array}$ & $\begin{array}{l}\text { Midsize Banks } \\
\text { \$10 B - \$50 B }\end{array}$ & $\begin{array}{c}\begin{array}{c}\text { Large } \\
\text { Banks }\end{array} \\
\$ 50 \text { B }-\$ 250 \text { B } \\
\end{array}$ & $\begin{array}{c}\text { Largest Banks } \\
>\$ 250 \mathrm{~B}\end{array}$ \\
\hline & $n=268$ & $n=54$ & $n=157$ & $n=35$ & $n=12$ & $n=10$ \\
\hline & Mean & Mean & Mean & Mean & Mean & Mean \\
\hline $\begin{array}{l}\text { 1. Book Value Assets } \\
(1,000 \mathrm{~s})\end{array}$ & $51,051,954$ & 720,540 & $3,230,694$ & $20,489,637$ & $115,839,244$ & $1,102,858,733$ \\
\hline $\begin{array}{l}\text { 2. Noninterest } \\
\text { Expense/ } \\
\text { Total Revenue }\end{array}$ & 0.634 & 0.676 & 0.631 & 0.598 & 0.613 & 0.615 \\
\hline $\begin{array}{l}\text { 3. Total Revenue/ } \\
\text { Assets }\end{array}$ & 0.049 & 0.050 & 0.048 & 0.048 & 0.054 & 0.052 \\
\hline $\begin{array}{l}\text { 4. Investment } \\
\text { Opportunity Ratio }\end{array}$ & 1.400 & 1.742 & 1.363 & 1.199 & 1.193 & 1.091 \\
\hline 5. Tobin's $q$ Ratio & 1.049 & 1.006 & 1.059 & 1.069 & 1.058 & 1.033 \\
\hline $\begin{array}{l}\text { 6. Noise-Adjusted } \\
\text { Tobin's } q \text { Ratio } \\
\end{array}$ & 1.047 & 0.990 & 1.062 & 1.074 & 1.054 & 1.033 \\
\hline $\begin{array}{l}\text { 7. Market-Value } \\
\text { Inefficiency Ratio }\end{array}$ & 0.268 & 0.525 & 0.251 & 0.080 & 0.068 & 0.045 \\
\hline
\end{tabular}




\section{Table 2A: Two-Sample t-Tests for Equal Means of Two Size Groups: Year 2013}

statistical significance at 10\%: not significant significant

number in each box $=$ mean(size group in $\mathrm{y}$-axis) - mean(size group in $\mathrm{x}$-axis )
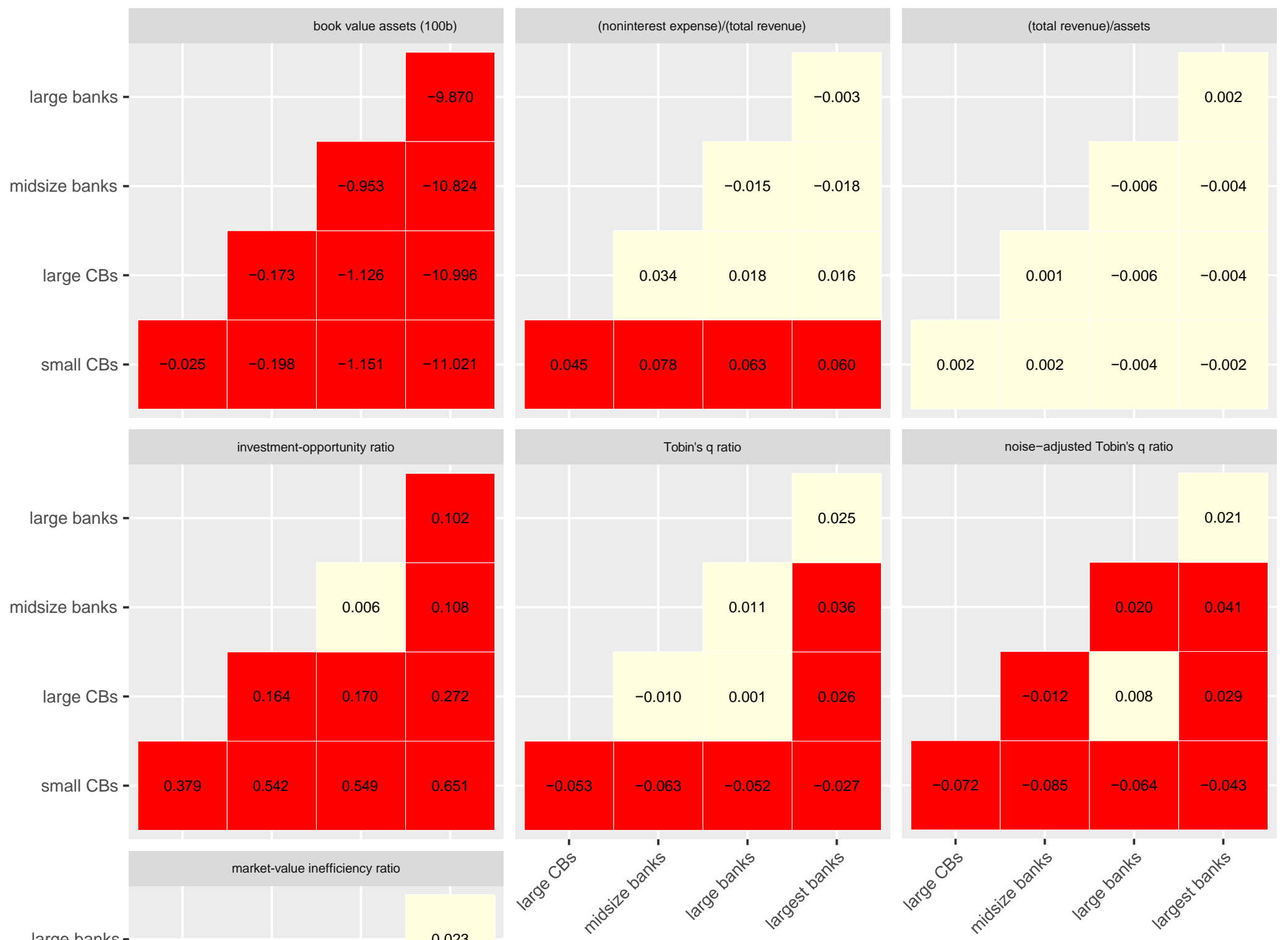

large banks -

0.023

midsize banks -

market-value inefficiency ratio

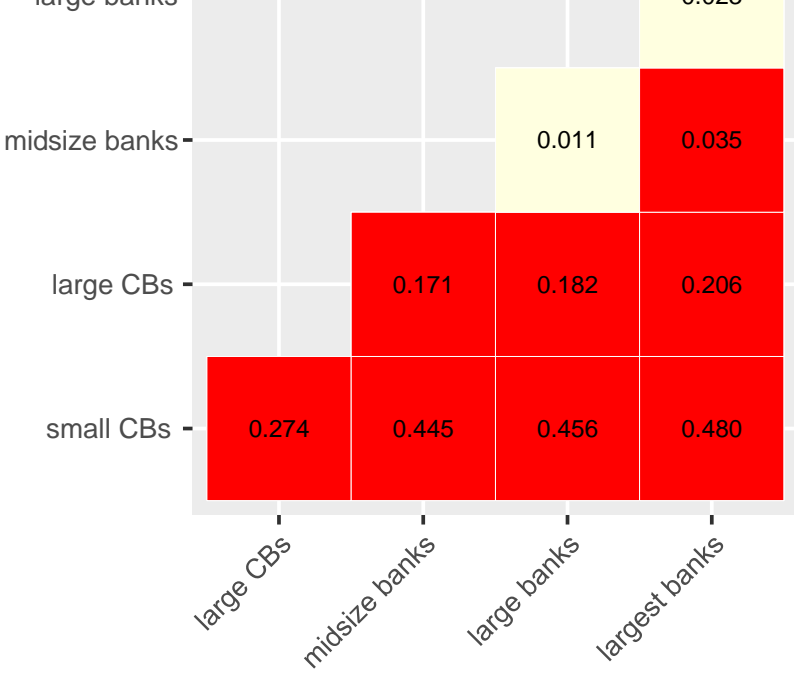




\section{Table 3}

\section{Operating Costs}

\section{Sample Partitioned by Size Group Based on Consolidated Assets}

The data set includes 761 top-tier bank holding companies at the end of 2013. Small community banks have consolidated assets less than $\$ 1$ billion, large community banks have consolidated assets from $\$ 1$ billion up to $\$ 10$ billion, and midsize banks have assets between $\$ 10$ billion and $\$ 50$ billion. To illustrate the differences between these banks and larger banks, we include in the table large banks with assets between $\$ 50$ billion and $\$ 250$ billion and the largest banks with assets exceeding $\$ 250$ billion.

Noninterest expense includes the following categories of expenses: salaries and benefits, premises and fixed assets, and "other noninterest expenses." Other noninterest expenses include such expenses as those related to data processing, legal,

telecommunications, the FDIC assessment, accounting and auditing, and advertising and marketing; however, reporting the expense in these categories is required only if the amount exceeds $\$ 25,000$ and 3 percent of the total noninterest expense. As a result of this restriction, many banks do not report all categories of the breakdown. Thus, we analyze only the aggregate "other noninterest expense."

Table 3 A provides two-sample $t$ tests for equal means of pairs of size groups.

\begin{tabular}{|c|c|c|c|c|c|c|}
\hline \multirow{3}{*}{ Variable } & \multicolumn{6}{|c|}{ Size Groups } \\
\hline & Full Sample & $\begin{array}{c}\text { Small Community } \\
\text { Banks } \\
<\$ 1 \mathrm{~B}\end{array}$ & $\begin{array}{c}\begin{array}{c}\text { Large } \\
\text { Community } \\
\text { Banks }\end{array} \\
\text { \$1 B - \$10 B }\end{array}$ & $\begin{array}{l}\text { Midsize Banks } \\
\$ 10 \text { B - \$50 B }\end{array}$ & $\begin{array}{c}\text { Large } \\
\text { Banks } \\
\text { \$50 B - \$250 B }\end{array}$ & $\begin{array}{c}\text { Largest } \\
\text { Banks } \\
>\$ 250 \mathrm{~B}\end{array}$ \\
\hline & Mean & Mean & Mean & Mean & Mean & Mean \\
\hline $\begin{array}{l}\text { 1. Book Value Assets } \\
(1,000 \mathrm{~s})\end{array}$ & $20,258,959$ & 671,480 & $2,620,271$ & $20,466,676$ & $117,745,400$ & $1,028,963,747$ \\
\hline $\begin{array}{l}\text { 2. Noninterest } \\
\text { Expense/ } \\
\text { Revenue }\end{array}$ & 0.655 & 0.685 & 0.634 & 0.590 & 0.684 & 0.620 \\
\hline $\begin{array}{l}\text { 3. Other Noninterest } \\
\text { Expense/ } \\
\text { Revenue }\end{array}$ & 0.218 & 0.237 & 0.202 & 0.197 & 0.219 & 0.238 \\
\hline $\begin{array}{l}\text { 4. Premises and } \\
\text { Fixed Assets } \\
\text { Expenses/ } \\
\text { Revenue }\end{array}$ & 0.081 & 0.084 & 0.080 & 0.076 & 0.078 & 0.054 \\
\hline $\begin{array}{l}\text { 5. Salaries and } \\
\text { Benefits/ } \\
\text { Revenue }\end{array}$ & 0.348 & 0.360 & 0.343 & 0.310 & 0.327 & 0.310 \\
\hline
\end{tabular}


Table 3A: Two-Sample t Tests for Equal Means of Two Size Groups: Year 2013

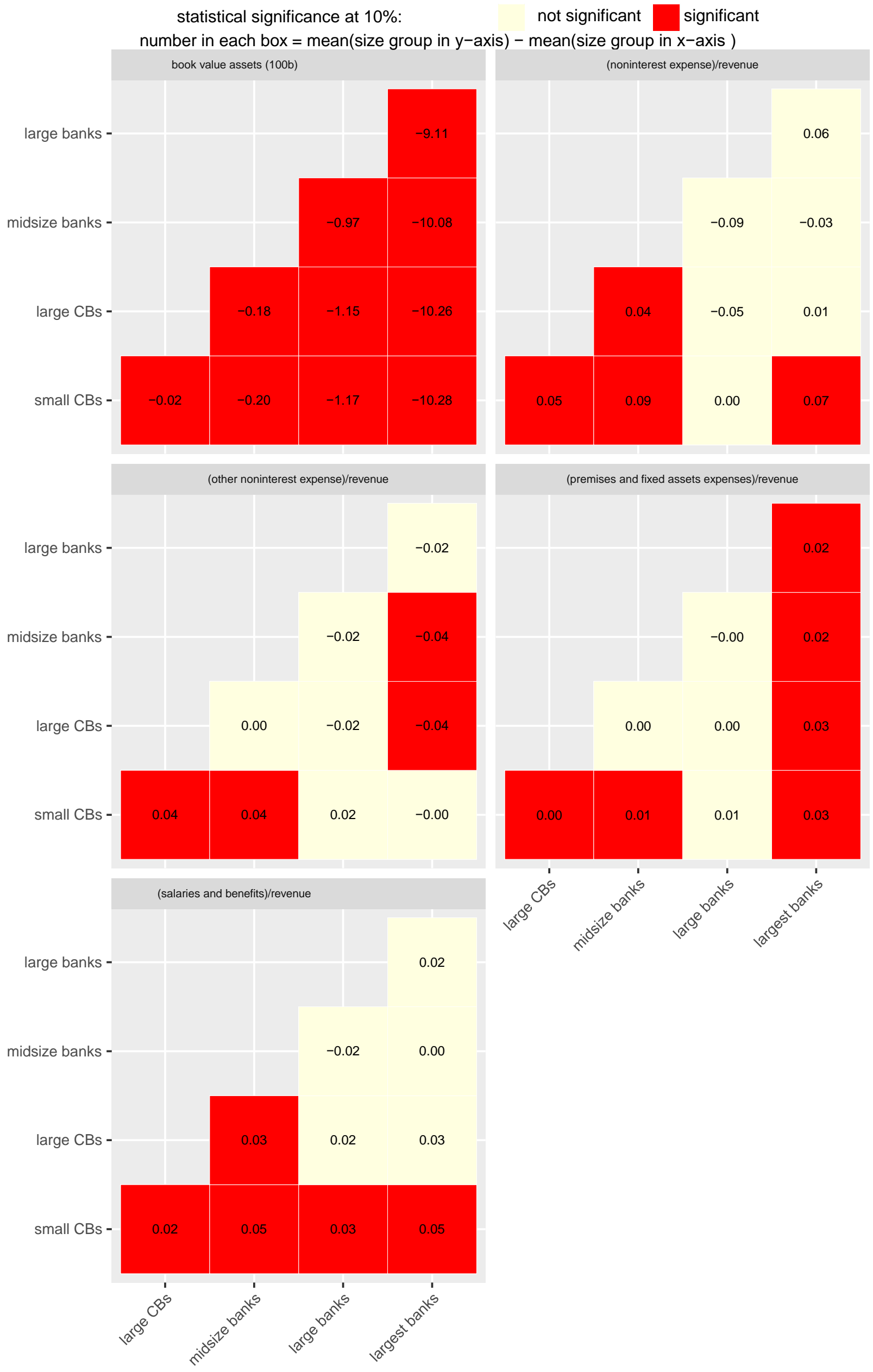




\section{Table 4}

\section{Asset Allocation and Quality and Off-Balance-Sheet Activity Sample Partitioned by Size Group Based on Consolidated Assets}

The data set includes 761 top-tier bank holding companies at the end of 2013. Small community banks have consolidated assets less than $\$ 1$ billion, large community banks have consolidated assets from $\$ 1$ billion up to $\$ 10$ billion, and midsize banks have assets between $\$ 10$ billion and $\$ 50$ billion. To illustrate the differences between these banks and larger banks, we include in the table large banks with assets between $\$ 50$ billion and $\$ 250$ billion and the largest banks with assets exceeding $\$ 250$ billion.

*The sample size for data on small business loans is smaller: $n=290$ for small community banks, $n=309$ for large community banks, $\mathrm{n}=36$ for midsize banks, $\mathrm{n}=12$ for large banks, and $\mathrm{n}=10$ for the largest banks.

Total business loans include small business loans, which are defined as business loans with an initial principal balance of less than $\$ 1$ million. Liquid assets are defined as the sum of cash, balances at other financial institutions, federal funds sold, securities, and securities sold under agreement to repurchase.

Table 4A provides two-sample t tests for equal means of pairs of size groups.

\begin{tabular}{|c|c|c|c|c|c|c|}
\hline \multirow[t]{3}{*}{ Variable } & Full Sample & $\begin{array}{c}\text { Small } \\
\text { Community } \\
\text { Banks } \\
<\text { <1 B }\end{array}$ & $\begin{array}{c}\text { Large } \\
\text { Community } \\
\text { Banks } \\
\text { \$1 B - \$10 B }\end{array}$ & $\begin{array}{c}\text { Midsize } \\
\text { Banks } \\
\text { \$10 B - \$50 B }\end{array}$ & $\begin{array}{c}\begin{array}{c}\text { Large } \\
\text { Banks }\end{array} \\
\text { \$50 B-\$250 B }\end{array}$ & $\begin{array}{l}\text { Largest } \\
\text { Banks } \\
>\$ 250 \mathrm{~B}\end{array}$ \\
\hline & $n=761$ & $n=335$ & $n=357$ & $n=40$ & $n=18$ & $n=11$ \\
\hline & Mean & Mean & Mean & Mean & Mean & Mean \\
\hline $\begin{array}{l}\text { 1. Book Value } \\
\text { Assets }(1,000 s)\end{array}$ & $20,258,959$ & 671,480 & $2,620,271$ & $20,466,676$ & $117,745,400$ & $1,028,963,747$ \\
\hline $\begin{array}{l}\text { 2. Total } \\
\text { Loans/Assets }\end{array}$ & 0.633 & 0.632 & 0.642 & 0.638 & 0.617 & 0.388 \\
\hline $\begin{array}{l}\text { 3. Real Estate } \\
\text { (RE)Loans/ } \\
\text { Assets }\end{array}$ & 0.465 & 0.490 & 0.468 & 0.387 & 0.284 & 0.159 \\
\hline $\begin{array}{l}\text { 4. Residential RE } \\
\text { Loans/Assets }\end{array}$ & 0.156 & 0.162 & 0.153 & 0.147 & 0.159 & 0.112 \\
\hline $\begin{array}{l}\text { 5. Commercial RE } \\
\text { Loans/Assets }\end{array}$ & 0.308 & 0.329 & 0.315 & 0.240 & 0.125 & 0.043 \\
\hline $\begin{array}{l}\text { 6. Consumer } \\
\text { Loans/Assets }\end{array}$ & 0.032 & 0.026 & 0.031 & 0.041 & 0.109 & 0.085 \\
\hline $\begin{array}{l}\text { 7. Total Business } \\
\text { Loans/ Assets }\end{array}$ & 0.100 & 0.083 & 0.108 & 0.153 & 0.161 & 0.077 \\
\hline $\begin{array}{l}\text { 8. Small Business } \\
\text { Loans/ Assets* }\end{array}$ & 0.041 & 0.043 & 0.043 & 0.031 & 0.018 & 0.010 \\
\hline $\begin{array}{l}\text { 9. Liquid Assets/ } \\
\text { Assets }\end{array}$ & 0.303 & 0.310 & 0.297 & 0.279 & 0.280 & 0.387 \\
\hline $\begin{array}{l}\text { 10. Noninterest } \\
\text { Income/ } \\
\text { Total Revenue } \\
\end{array}$ & 0.222 & 0.199 & 0.225 & 0.259 & 0.353 & 0.497 \\
\hline $\begin{array}{l}\text { 11. Nonperforming } \\
\text { Loans/Assets }\end{array}$ & 0.030 & 0.037 & 0.024 & 0.022 & 0.019 & 0.024 \\
\hline $\begin{array}{l}\text { 12. Average } \\
\text { Contractual } \\
\text { Interest Rate on } \\
\text { Loans }\end{array}$ & 0.050 & 0.053 & 0.048 & 0.046 & 0.043 & 0.044 \\
\hline
\end{tabular}


Table 4A: Two-Sample t Tests for Equal Means of Two Size Groups: Year 2013

statistical significance at 10\%: not significant
number in each box = mean(size group in $\mathrm{y}$-axis) - mean(size group in $\mathrm{x}$-axis )

book value assets (100b)

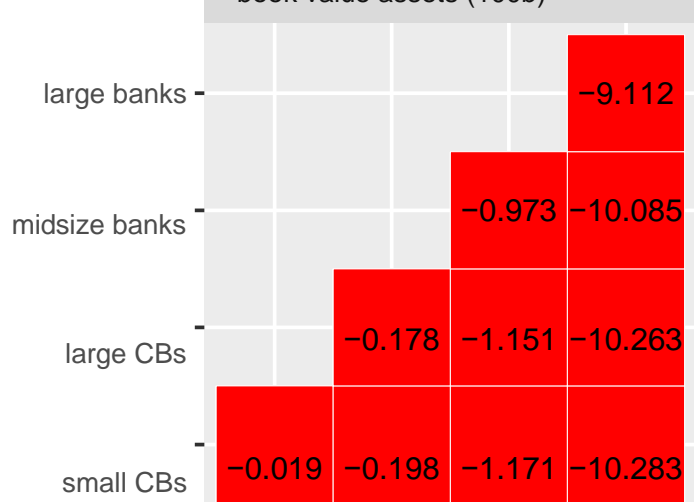

(residential RE loans)/assets

large banks -

midsize banks ${ }^{-}$

$-0.0120 .035$

large CBs

$\begin{array}{lllll} & & & & \\ \text { small CBs } & 0.009 & 0.015 & 0.002 & 0.050\end{array}$

(total business loans)/assets

large banks

midsize banks

$-0.008$

0.076

large CBs

$-0.025-0.070-0.078$

0.006

(noninterest income)/(total revenue)
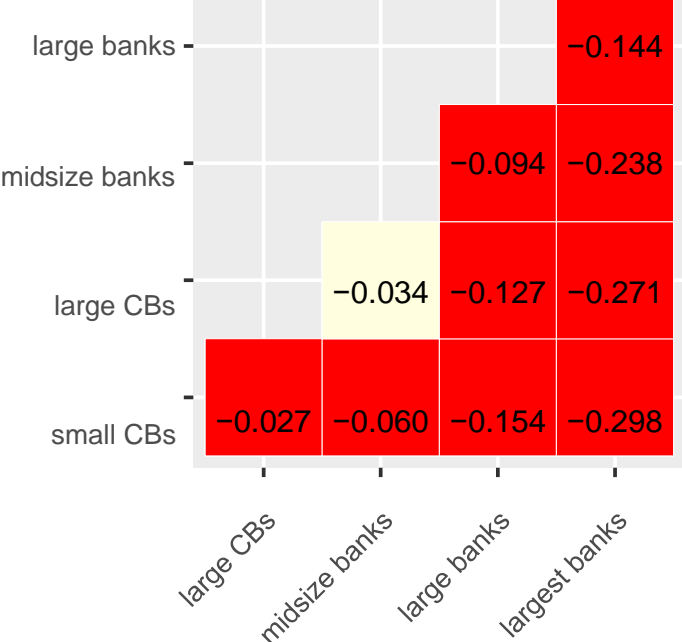

loans/assets

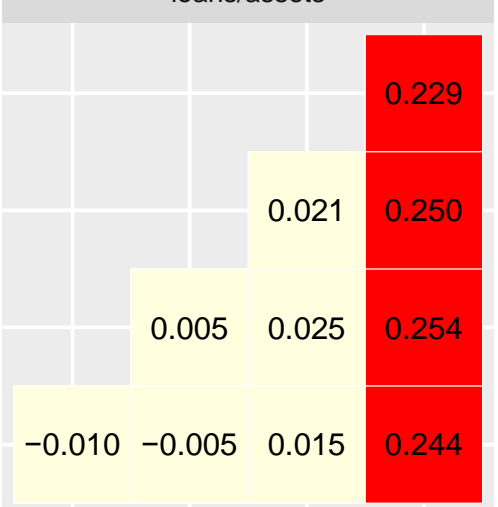

(commercial RE loans)/assets

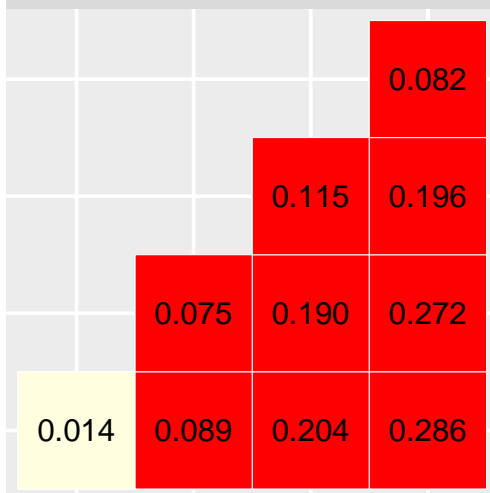

(small business loans)/assets

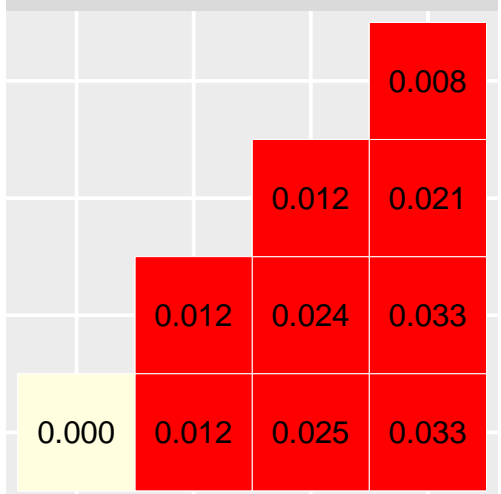

(nonperforming loans)/assets

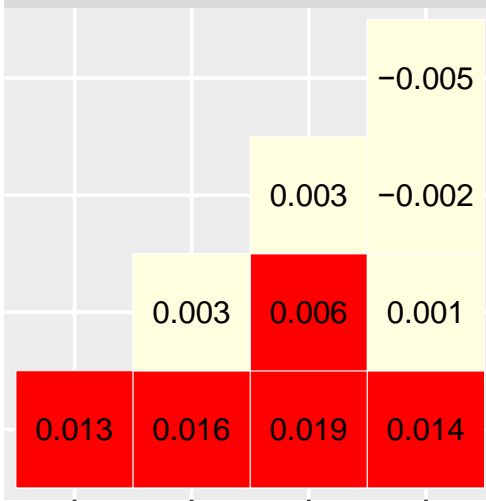

(real estate loans)/assets

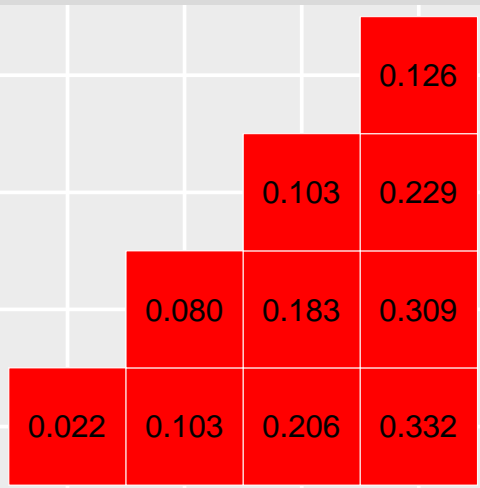

(consumer loans)/assets

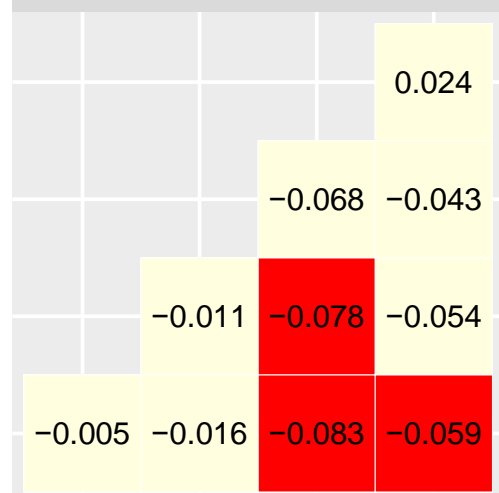

(liquid assets)/assets

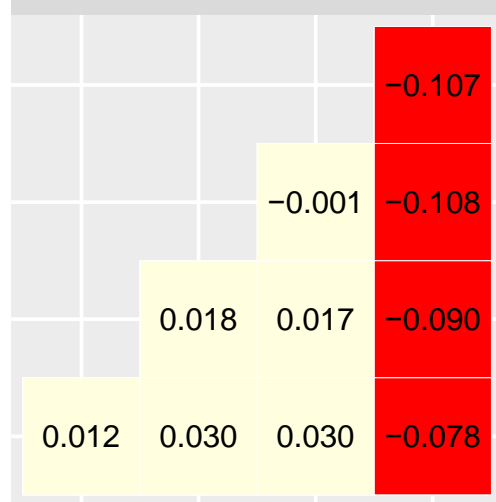

contractual interest rate on loans

$-0.002$

$0.003 \quad 0.002$

$\begin{array}{lll}0.002 & 0.006 & 0.004\end{array}$

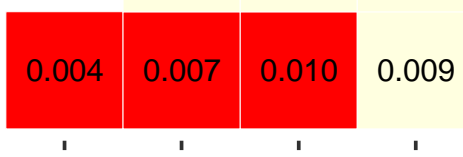




\section{Table 5}

\section{Best-Practice Commercial and Industrial Loan Performance and Lending Inefficiency Sample Partitioned by Size Group Based on Consolidated Assets}

The data set includes 652 top-tier bank holding companies at the end of 2013 with data on the average contractual loan rate on business loans and plausible values of nonperforming business loans: banks with business loans less than 0.01 of total loans and with values of nonperforming business loans to total business loans less than 0.001 and greater than 0.40 were trimmed.

Small community banks have consolidated assets less than $\$ 1$ billion, large community banks have consolidated assets from $\$ 1$ billion up to $\$ 10$ billion, and midsize banks have assets between $\$ 10$ billion and $\$ 50$ billion. To illustrate the differences between these banks and larger banks, we include in the table large banks with assets between $\$ 50$ billion and $\$ 250$ billion and the largest banks with assets exceeding $\$ 250$ billion.

The best-practice business nonperforming loan ratio is obtained from a stochastic frontier estimation of the lower envelope of business nonperforming loan ratios conditioned on the $\log$ (amount of business loans) and the log squared, the ratio of business loans to total loans and total loans to assets, the GDP growth rate, an index of market concentration, and the average contractual business loan rate. Lending inefficiency is gauged by the ratio of nonperforming business loans in excess of the best-practice ratio.

Table $5 \mathrm{~A}$ provides two-sample $t$ tests for equal means of pairs of size groups.

\begin{tabular}{|c|c|c|c|c|c|c|}
\hline \multirow{4}{*}{ Variable } & \multicolumn{6}{|c|}{ Size Groups } \\
\hline & Full Sample & $\begin{array}{c}\text { Small Community } \\
\text { Banks } \\
<\$ 1 \mathrm{~B}\end{array}$ & $\begin{array}{c}\begin{array}{c}\text { Large } \\
\text { Community } \\
\text { Banks }\end{array} \\
\text { \$1 B - \$10 B }\end{array}$ & $\begin{array}{l}\text { Midsize Banks } \\
\$ 10 \text { B - \$50 B }\end{array}$ & $\begin{array}{c}\text { Large } \\
\text { Banks } \\
\\
\$ 50 \text { B }-\$ 250 \text { B }\end{array}$ & $\begin{array}{c}\text { Largest } \\
\text { Banks } \\
>\$ 250 \mathrm{~B}\end{array}$ \\
\hline & $n=652$ & $n=278$ & $n=316$ & $n=38$ & $\mathrm{n}=10$ & $n=10$ \\
\hline & Mean & Mean & Mean & Mean & Mean & Mean \\
\hline $\begin{array}{l}\text { 1. Book Value Assets } \\
(1,000 \mathrm{~s})\end{array}$ & $21,245,570$ & 681,968 & $2,563,137$ & $19,902,179$ & $106,770,317$ & $1,102,858,733$ \\
\hline $\begin{array}{l}\text { 2. Business } \\
\text { Loans/Total Loans }\end{array}$ & 0.158 & 0.132 & 0.164 & 0.254 & 0.298 & 0.180 \\
\hline $\begin{array}{l}\text { 3. Business Average } \\
\text { Contractual Loan Rate }\end{array}$ & 0.053 & 0.057 & 0.051 & 0.042 & 0.034 & 0.032 \\
\hline $\begin{array}{l}\text { 4. Nonperforming } \\
\text { Business } \\
\text { Loans/Business Loans }\end{array}$ & 0.028 & 0.037 & 0.023 & 0.019 & 0.011 & 0.018 \\
\hline $\begin{array}{l}\text { 5. Best-Practice } \\
\text { Nonperforming } \\
\text { Business } \\
\text { Loans/Business Loans }\end{array}$ & 0.002 & 0.001 & 0.002 & 0.003 & 0.004 & 0.006 \\
\hline $\begin{array}{l}\text { 6. Nonperforming } \\
\text { Business Loans in } \\
\text { Excess of Best- } \\
\text { Practice/Business } \\
\text { Loans }\end{array}$ & 0.027 & 0.036 & 0.021 & 0.016 & 0.007 & 0.012 \\
\hline
\end{tabular}


Table 5A: Two-Sample t Tests for Equal Means of Two Size Groups: Year 2013

statistical significance at 10\%: not significant significant number in each box = mean(size group in $y$-axis) - mean(size group in $x$-axis )

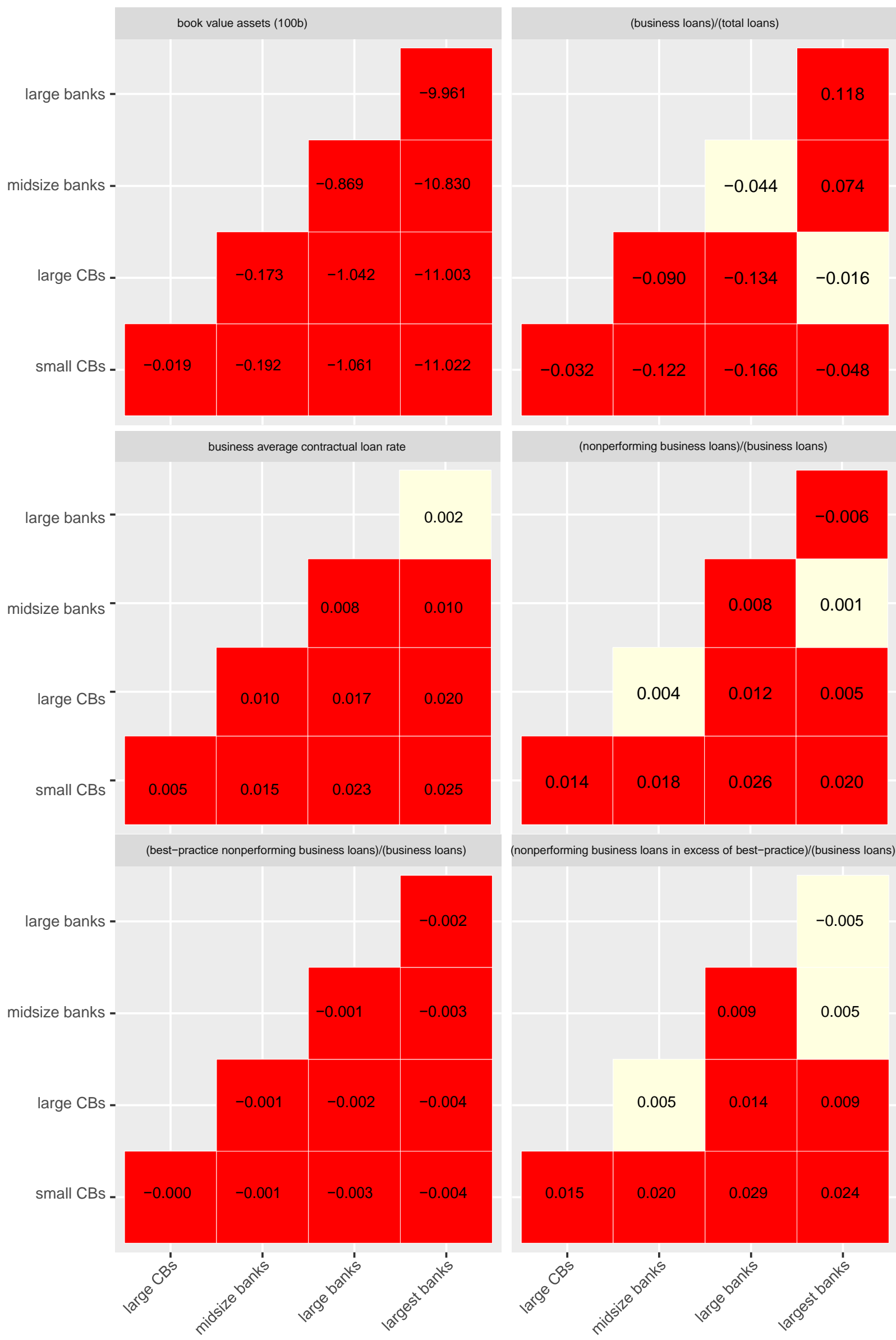




\section{Table 6}

\section{Best-Practice Commercial Real Estate Loan Performance and Lending Inefficiency Sample Partitioned by Size Group Based on Consolidated Assets}

The data set includes 689 top-tier bank holding companies at the end of 2013 with plausible values of nonperforming commercial real estate loans (CRE): banks with CRE loans less than 0.01 of total loans and with values of nonperforming CRE loans to total CRE loans less than 0.001 and greater than 0.40 were trimmed.

Small community banks have consolidated assets less than $\$ 1$ billion, large community banks have consolidated assets from $\$ 1$ billion up to $\$ 10$ billion, and midsize banks have assets between $\$ 10$ billion and $\$ 50$ billion. To illustrate the differences between these banks and larger banks, we include in the table large banks with assets between $\$ 50$ billion and $\$ 250$ billion and the largest banks with assets exceeding $\$ 250$ billion.

The best-practice CRE nonperforming loan ratio is obtained from a stochastic frontier estimation of the lower envelope of CRE nonperforming loan ratios conditioned on the $\log$ (amount of CRE) and log squared, the ratio of CRE loans to the total amount of loans and total loans to assets, the GDP growth rate, an index of market concentration, and the average contractual CRE loan rate. Lending inefficiency is gauged by the ratio of nonperforming CRE loans in excess of the best-practice ratio.

Table 6A provides two-sample $t$ tests for equal means of pairs of size groups.

\begin{tabular}{|c|c|c|c|c|c|c|}
\hline \multirow{4}{*}{ Variable } & \multicolumn{6}{|c|}{ Size Groups } \\
\hline & Full Sample & $\begin{array}{c}\text { Small Community } \\
\text { Banks } \\
<\$ 1 \mathrm{~B} \\
\end{array}$ & $\begin{array}{c}\begin{array}{c}\text { Large } \\
\text { Community } \\
\text { Banks }\end{array} \\
\text { \$1 B - \$10 B }\end{array}$ & $\begin{array}{l}\text { Midsize Banks } \\
\$ 10 \text { B - \$50 B }\end{array}$ & $\begin{array}{c}\begin{array}{c}\text { Large } \\
\text { Banks }\end{array} \\
\$ 50 \text { B }-\$ 250 \text { B }\end{array}$ & $\begin{array}{l}\text { Largest } \\
\text { Banks } \\
>\$ 250 \mathrm{~B}\end{array}$ \\
\hline & $n=689$ & $n=310$ & $n=322$ & $\mathbf{n}=37$ & $\mathrm{n}=10$ & \\
\hline & Mean & Mean & Mean & Mean & Mean & Mean \\
\hline $\begin{array}{l}\text { 1. Book Value Assets } \\
(1,000 \mathrm{~s})\end{array}$ & $20,132,896$ & 671,160 & $2,554,595$ & $20,125,287$ & $106,770,317$ & $1,102,858,733$ \\
\hline $\begin{array}{l}\text { 2. Commercial Real } \\
\text { Estate Loans/Total } \\
\text { Loans }\end{array}$ & 0.489 & 0.524 & 0.489 & 0.375 & 0.226 & 0.087 \\
\hline $\begin{array}{l}\text { 3. CRE Average } \\
\text { Contractual Lending } \\
\text { Rate }\end{array}$ & 0.050 & 0.052 & 0.049 & 0.048 & 0.042 & 0.036 \\
\hline $\begin{array}{l}\text { 4. Nonperforming CRE } \\
\text { Loans/ CRE Loans }\end{array}$ & 0.036 & 0.044 & 0.029 & 0.030 & 0.029 & 0.030 \\
\hline $\begin{array}{l}\text { 5. Best-Practice } \\
\text { Nonperforming CRE } \\
\text { Loans/ CRE Loans }\end{array}$ & 0.005 & 0.005 & 0.004 & 0.006 & 0.006 & 0.005 \\
\hline $\begin{array}{l}\text { 6. Nonperforming CRE } \\
\text { Loans in Excess of } \\
\text { Best-Practice/CRE } \\
\text { Loans }\end{array}$ & 0.032 & 0.040 & 0.025 & 0.024 & 0.023 & 0.024 \\
\hline
\end{tabular}


Table 6A: Two-Sample t Tests for Equal Means of Two Size Groups: Year 2013

statistical significance at $10 \%$ : not significant significant

number in each box = mean(size group in $y$-axis) - mean(size group in $x$-axis )

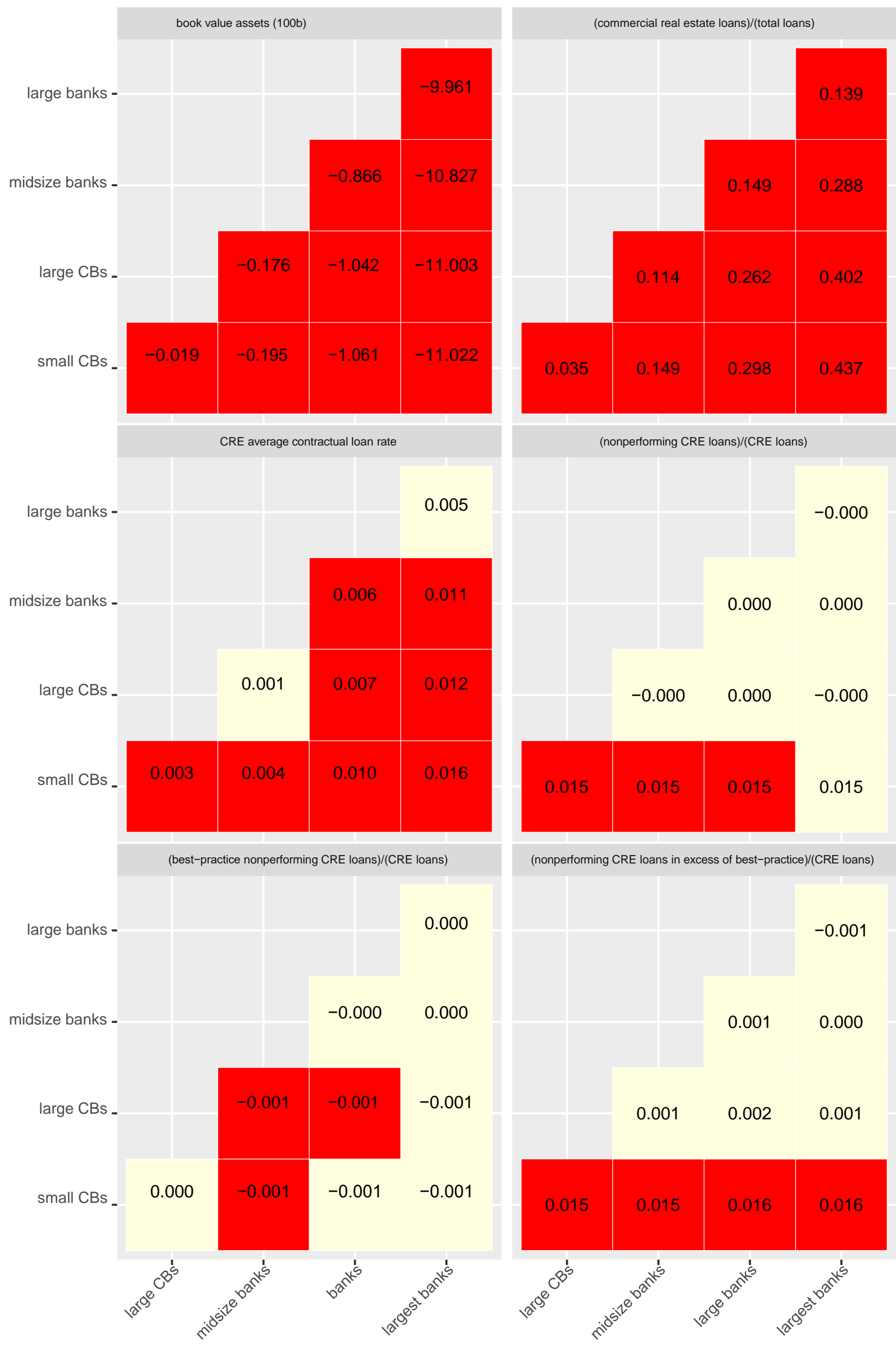




\section{Table 7 \\ Relationship of Financial Performance Measured by ROA and ROA Shortfall to Investment Strategy and Small Business Lending}

The data set includes 657 top-tier bank holding companies at the end of 2013 that have the data required by the regressions. Small community banks have consolidated assets less than $\$ 1$ billion, large community banks have consolidated assets from $\$ 1$ billion up to $\$ 10$ billion, and midsize banks have assets between $\$ 10$ billion and $\$ 50$ billion. To illustrate the differences between these banks and larger banks, we include in the table large banks with assets between $\$ 50$ billion and $\$ 250$ billion and the largest banks with assets exceeding $\$ 250$ billion, which we group together since their numbers are small.

ROA is defined by the ratio of net income before taxes and extraordinary items to consolidated assets. ROA shortfall is given by the stochastic ROA frontier and is the difference between the highest potential ROA for a given standard deviation and the achieved ROA. Regressions are estimated with OLS, and standard errors are heteroscedasticity consistent. Parameter estimates in bold are significantly different from zero at stricter than $10 \%$.

\begin{tabular}{|c|c|c|c|c|c|c|c|c|}
\hline \multirow{4}{*}{ Variable } & \multicolumn{8}{|c|}{ Dependent Variable by Size Group } \\
\hline & \multicolumn{2}{|c|}{$\begin{array}{c}\text { Small Community } \\
\text { Banks }\end{array}$} & \multicolumn{2}{|c|}{$\begin{array}{c}\text { Large Community } \\
\text { Banks }\end{array}$} & \multicolumn{2}{|c|}{ Midsize Banks } & \multicolumn{2}{|c|}{$\begin{array}{c}\text { Large and Largest } \\
\text { Banks }\end{array}$} \\
\hline & ROA & $\begin{array}{c}\text { ROA } \\
\text { Shortfall }\end{array}$ & ROA & $\begin{array}{c}\text { ROA } \\
\text { Shortfall }\end{array}$ & ROA & $\begin{array}{c}\text { ROA } \\
\text { Shortfall }\end{array}$ & ROA & $\begin{array}{c}\text { ROA } \\
\text { Shortfall }\end{array}$ \\
\hline & $\begin{array}{c}\text { Parameter } \\
\text { Estimate } \\
(\mathrm{Pr}>|\mathrm{t}|)\end{array}$ & $\begin{array}{c}\text { Parameter } \\
\text { Estimate } \\
(\mathrm{Pr}>|\mathrm{t}|)\end{array}$ & $\begin{array}{c}\text { Parameter } \\
\text { Estimate } \\
(\operatorname{Pr}>|t|)\end{array}$ & $\begin{array}{c}\text { Parameter } \\
\text { Estimate } \\
(\operatorname{Pr}>|\mathrm{t}|)\end{array}$ & $\begin{array}{c}\text { Parameter } \\
\text { Estimate } \\
(\operatorname{Pr}>|t|)\end{array}$ & $\begin{array}{c}\text { Parameter } \\
\text { Estimate } \\
(\operatorname{Pr}>|t|)\end{array}$ & $\begin{array}{c}\text { Parameter } \\
\text { Estimate } \\
(\operatorname{Pr}>|t|)\end{array}$ & $\begin{array}{c}\text { Parameter } \\
\text { Estimate } \\
(\operatorname{Pr}>|t|)\end{array}$ \\
\hline Intercept & $\begin{array}{c}-\mathbf{- 1 4 . 3 2 1} \\
(<.000)\end{array}$ & $\begin{array}{c}\mathbf{5 . 5 0 1} \\
(<.000)\end{array}$ & $\begin{array}{l}-3.560 \\
(0.008)\end{array}$ & $\begin{array}{c}1.229 \\
(0.001)\end{array}$ & $\begin{array}{l}-1.898 \\
(0.734)\end{array}$ & $\begin{array}{c}1.336 \\
(0.641)\end{array}$ & $\begin{array}{c}\mathbf{- 2 6 . 5 0 4} \\
(0.040)\end{array}$ & $\begin{array}{l}\mathbf{1 1 . 6 1 5} \\
(0.024)\end{array}$ \\
\hline $\begin{array}{l}\text { log (Book Value } \\
\text { Assets }(1,000 \mathrm{~s}) \text { ) }\end{array}$ & $\begin{array}{c}\mathbf{0 . 3 6 4} \\
(0.009)\end{array}$ & $\begin{array}{l}\mathbf{- 0 . 1 5 9} \\
(0.037)\end{array}$ & $\begin{array}{l}-\mathbf{0 . 1 0 2} \\
(0.047)\end{array}$ & $\begin{array}{l}-0.009 \\
(0.644)\end{array}$ & $\begin{array}{c}0.232 \\
(0.427)\end{array}$ & $\begin{array}{l}-0.116 \\
(0.454)\end{array}$ & $\begin{array}{c}\mathbf{0 . 6 8 9} \\
(0.066)\end{array}$ & $\begin{array}{l}-0.274 \\
(0.096)\end{array}$ \\
\hline $\begin{array}{l}\text { Total } \\
\text { Loans/Assets }\end{array}$ & $\begin{array}{c}\mathbf{9 . 8 2 6} \\
(0.002)\end{array}$ & $\begin{array}{l}-\mathbf{- 2 . 7 5 2} \\
(0.062)\end{array}$ & $\begin{array}{c}4.482 \\
(<.000)\end{array}$ & $\begin{array}{l}-\mathbf{- 1 . 0 5 2} \\
(0.003)\end{array}$ & $\begin{array}{l}-0.246 \\
(0.939)\end{array}$ & $\begin{array}{c}1.510 \\
(0.362)\end{array}$ & $\begin{array}{l}-5.015 \\
(0.300)\end{array}$ & $\begin{array}{c}\mathbf{5 . 0 1 2} \\
(0.049)\end{array}$ \\
\hline $\begin{array}{l}\text { Residential RE } \\
\text { Loans/Assets }\end{array}$ & $\begin{array}{l}-0.685 \\
(0.321) \\
\end{array}$ & $\begin{array}{c}0.218 \\
(0.321) \\
\end{array}$ & $\begin{array}{l}-\mathbf{- 2 . 0 1 9} \\
(<.000 \\
\end{array}$ & $\begin{array}{c}\mathbf{0 . 3 8 6} \\
(0.006) \\
\end{array}$ & $\begin{array}{l}-0.793 \\
(0.516) \\
\end{array}$ & $\begin{array}{l}-0.016 \\
(0.981)\end{array}$ & $\begin{array}{l}\mathbf{1 7 . 2 3 8} \\
(0.055) \\
\end{array}$ & $\begin{array}{c}-\mathbf{- 1 0 . 7 5 1} \\
(0.009)\end{array}$ \\
\hline $\begin{array}{l}\text { Commercial RE } \\
\text { Loans/Assets }\end{array}$ & $\begin{array}{l}-0.927 \\
(0.277)\end{array}$ & $\begin{array}{c}0.268 \\
(0.406)\end{array}$ & $\begin{array}{l}-0.904 \\
(0.131)\end{array}$ & $\begin{array}{c}0.110 \\
(0.417)\end{array}$ & $\begin{array}{l}-0.268 \\
(0.834)\end{array}$ & $\begin{array}{l}-0.461 \\
(0.503)\end{array}$ & $\begin{array}{l}\mathbf{1 3 . 5 4 0} \\
(0.039)\end{array}$ & $\begin{array}{l}-\mathbf{5 . 9 6 3} \\
(0.028)\end{array}$ \\
\hline $\begin{array}{l}\text { Consumer } \\
\text { Loans/Assets }\end{array}$ & $\begin{array}{c}0.702 \\
(0.387) \\
\end{array}$ & $\begin{array}{l}-0.207 \\
(0.493)\end{array}$ & $\begin{array}{l}-0.798 \\
(0.191) \\
\end{array}$ & $\begin{array}{l}-0.071 \\
(0.608)\end{array}$ & $\begin{array}{l}-1.547 \\
(0.705) \\
\end{array}$ & $\begin{array}{l}-0.308 \\
(0.884)\end{array}$ & $\begin{array}{l}\mathbf{1 9 . 8 8 0} \\
(0.015) \\
\end{array}$ & $\begin{array}{l}\mathbf{- 9 . 5 6 5} \\
(0.005)\end{array}$ \\
\hline $\begin{array}{l}\text { Total Business } \\
\text { Loans/Assets }\end{array}$ & $\begin{array}{l}-1.547 \\
(0.228)\end{array}$ & $\begin{array}{c}0.593 \\
(0.281) \\
\end{array}$ & $\begin{array}{l}-\mathbf{- 3 . 1 7 9} \\
(<.000)\end{array}$ & $\begin{array}{c}\mathbf{0 . 5 5 7} \\
(0.002) \\
\end{array}$ & $\begin{array}{l}-0.077 \\
(0.958) \\
\end{array}$ & $\begin{array}{l}-0.077 \\
(0.921)\end{array}$ & $\begin{array}{l}\mathbf{1 5 . 6 3 7} \\
(0.048) \\
\end{array}$ & $\begin{array}{l}-\mathbf{- 9 . 7 2 4} \\
(0.007)\end{array}$ \\
\hline $\begin{array}{l}\text { Small Business } \\
\text { Loans/Assets }\end{array}$ & $\begin{array}{c}\mathbf{3 . 4 8 9} \\
(0.0324) \\
\end{array}$ & $\begin{array}{r}-\mathbf{- 1 . 5 8 0} \\
(0.098) \\
\end{array}$ & $\begin{array}{c}4.755 \\
(<.000) \\
\end{array}$ & $\begin{array}{l}-0.469 \\
(0.123) \\
\end{array}$ & $\begin{array}{c}1.979 \\
(0.552) \\
\end{array}$ & $\begin{array}{l}-1.414 \\
(0.262) \\
\end{array}$ & $\begin{array}{r}60.899 \\
(0.193) \\
\end{array}$ & $\begin{array}{c}-42.507 \\
(0.029) \\
\end{array}$ \\
\hline $\begin{array}{l}\text { Liquid } \\
\text { Assets/Assets }\end{array}$ & $\begin{array}{c}\mathbf{8 . 4 0 5} \\
(0.008) \\
\end{array}$ & $\begin{array}{l}-\mathbf{- 2 . 2 9 1} \\
(0.092) \\
\end{array}$ & $\begin{array}{c}\mathbf{2 . 8 3 6} \\
(0.010) \\
\end{array}$ & $\begin{array}{l}-\mathbf{0 . 7 5 7} \\
(0.015) \\
\end{array}$ & $\begin{array}{c}0.143 \\
(0.973) \\
\end{array}$ & $\begin{array}{c}1.373 \\
(0.513) \\
\end{array}$ & $\begin{array}{c}\mathbf{8 . 2 7 6} \\
(0.037) \\
\end{array}$ & $\begin{array}{l}-\mathbf{- 3 . 9 2 6} \\
(0.010) \\
\end{array}$ \\
\hline $\begin{array}{l}\text { Noninterest } \\
\text { Income/ } \\
\text { Revenue }\end{array}$ & $\begin{array}{c}1.925 \\
(0.011)\end{array}$ & $\begin{array}{l}-0.371 \\
(0.181)\end{array}$ & $\begin{array}{c}\mathbf{0 . 9 1 9} \\
(0.010)\end{array}$ & $\begin{array}{l}-0.065 \\
(0.438)\end{array}$ & $\begin{array}{l}-0.358 \\
(0.667)\end{array}$ & $\begin{array}{l}-0.100 \\
(0.783)\end{array}$ & $\begin{array}{c}\mathbf{6 . 2 1 2} \\
(0.005)\end{array}$ & $\begin{array}{l}-2.219 \\
(0.008)\end{array}$ \\
\hline $\begin{array}{l}\text { Nonperforming } \\
\text { Loans/Assets }\end{array}$ & $\begin{array}{l}-2.439 \\
(0.181)\end{array}$ & $\begin{array}{l}\mathbf{1 . 1 9 1 6} \\
(0.052)\end{array}$ & $\begin{array}{l}\mathbf{- 8 . 2 6 8} \\
(<.000)\end{array}$ & $\begin{array}{c}\mathbf{3 . 0 2 5} \\
(<.000)\end{array}$ & $\begin{array}{c}\mathbf{- 1 6 . 0 0 5} \\
(0.058)\end{array}$ & $\begin{array}{l}\mathbf{1 1 . 5 5 7} \\
(0.027)\end{array}$ & $\begin{array}{c}-57.510 \\
(0.182)\end{array}$ & $\begin{array}{l}24.886 \\
(0.135)\end{array}$ \\
\hline $\begin{array}{l}\text { Deposits/(Depos } \\
\text { its + Other } \\
\text { Borrowed } \\
\text { Funds) }\end{array}$ & $\begin{array}{c}1.007 \\
(0.218)\end{array}$ & $\begin{array}{l}-0.361 \\
(0.157)\end{array}$ & $\begin{array}{l}-0.523 \\
(0.146)\end{array}$ & $\begin{array}{c}0.151 \\
(0.166)\end{array}$ & $\begin{array}{l}-0.116 \\
(0.928)\end{array}$ & $\begin{array}{l}-0.432 \\
(0.534)\end{array}$ & $\begin{array}{l}\mathbf{- 3 . 3 9 4} \\
(0.051)\end{array}$ & $\begin{array}{c}\mathbf{1 . 5 9 4} \\
(0.043)\end{array}$ \\
\hline $\begin{array}{l}\text { (Equity + Sub } \\
\text { Debt + Loan Loss } \\
\text { Reserves)/ } \\
\text { Assets }\end{array}$ & $\begin{array}{c}\mathbf{6 . 1 7 7} \\
(<.000)\end{array}$ & $\begin{array}{l}\mathbf{- 1 . 8 6 2} \\
(0.014)\end{array}$ & $\begin{array}{c}7.220 \\
(<.000)\end{array}$ & $\begin{array}{l}-1.222 \\
(0.004)\end{array}$ & $\begin{array}{c}1.069 \\
(0.861)\end{array}$ & $\begin{array}{c}0.386 \\
(0.892)\end{array}$ & $\begin{array}{l}\mathbf{5 0 . 3 9 8} \\
(0.036)\end{array}$ & $\begin{array}{c}\mathbf{- 2 1 . 7 8 0} \\
(0.020)\end{array}$ \\
\hline
\end{tabular}


Table 7 continued

\section{Relationship of Financial Performance Measured by ROA and ROA Shortfall to Investment Strategy and Small Business Lending}

\begin{tabular}{|c|c|c|c|c|c|c|c|c|}
\hline \multirow{4}{*}{ Variable } & \multicolumn{8}{|c|}{ Dependent Variable by Size Group } \\
\hline & \multicolumn{2}{|c|}{$\begin{array}{c}\text { Small Community } \\
\text { Banks }\end{array}$} & \multicolumn{2}{|c|}{$\begin{array}{c}\text { Large Community } \\
\text { Banks }\end{array}$} & \multicolumn{2}{|c|}{ Midsize Banks } & \multicolumn{2}{|c|}{$\begin{array}{c}\text { Large and Largest } \\
\text { Banks }\end{array}$} \\
\hline & ROA & $\begin{array}{c}\text { ROA } \\
\text { Shortfall }\end{array}$ & ROA & $\begin{array}{c}\text { ROA } \\
\text { Shortfall }\end{array}$ & ROA & $\begin{array}{c}\text { ROA } \\
\text { Shortfall }\end{array}$ & ROA & $\begin{array}{c}\text { ROA } \\
\text { Shortfall }\end{array}$ \\
\hline & $\begin{array}{l}\text { Parameter } \\
\text { Estimate } \\
(\operatorname{Pr}>|t|)\end{array}$ & $\begin{array}{l}\text { Parameter } \\
\text { Estimate } \\
(\operatorname{Pr}>|t|)\end{array}$ & $\begin{array}{l}\text { Parameter } \\
\text { Estimate } \\
(\operatorname{Pr}>|t|)\end{array}$ & $\begin{array}{l}\text { Parameter } \\
\text { Estimate } \\
(\operatorname{Pr}>|t|)\end{array}$ & $\begin{array}{l}\text { Parameter } \\
\text { Estimate } \\
(\operatorname{Pr}>|t|)\end{array}$ & $\begin{array}{l}\text { Parameter } \\
\text { Estimate } \\
(\operatorname{Pr}>|t|)\end{array}$ & $\begin{array}{l}\text { Parameter } \\
\text { Estimate } \\
(\operatorname{Pr}>|t|)\end{array}$ & $\begin{array}{c}\text { Parameter } \\
\text { Estimate } \\
(\operatorname{Pr}>|t|)\end{array}$ \\
\hline $\begin{array}{l}+1 \% \text { in Business Loans } \\
+1 \% \text { in Small Business } \\
\text { Loans }\end{array}$ & $\begin{array}{c}1.942 \\
(0.209)\end{array}$ & $\begin{array}{l}-0.986 \\
(0.183)\end{array}$ & $\begin{array}{c}1.576 \\
(0.122) \\
\end{array}$ & $\begin{array}{c}0.088 \\
(0.728) \\
\end{array}$ & $\begin{array}{c}1.902 \\
(0.556)\end{array}$ & $\begin{array}{l}-1.490 \\
(0.314)\end{array}$ & $\begin{array}{l}76.536 \\
(0.103)\end{array}$ & $\begin{array}{c}-52.231 \\
(0.003)\end{array}$ \\
\hline $\begin{array}{l}+1 \% \text { in Total Loans and } \\
+1 \% \text { in Business Loans }\end{array}$ & $\begin{array}{c}8.279 \\
(0.008) \\
\end{array}$ & $\begin{array}{l}-2.159 \\
(0.078) \\
\end{array}$ & $\begin{array}{c}1.303 \\
(0.239) \\
\end{array}$ & $\begin{array}{l}-0.495 \\
(0.110) \\
\end{array}$ & $\begin{array}{l}-0.323 \\
(0.930) \\
\end{array}$ & $\begin{array}{c}1.434 \\
(0.436) \\
\end{array}$ & $\begin{array}{l}\mathbf{1 0 . 6 2 2} \\
(0.006) \\
\end{array}$ & $\begin{array}{l}-4.712 \\
(<.000)\end{array}$ \\
\hline \multirow[t]{3}{*}{$\begin{array}{l}+1 \% \text { in Total Loans, } \\
+1 \% \text { in Business Loans } \\
+1 \% \text { in Small Business } \\
\text { Loans }\end{array}$} & $\begin{array}{l}11.768 \\
(0.000)\end{array}$ & $\begin{array}{l}-3.739 \\
(0.017)\end{array}$ & $\begin{array}{l}\mathbf{6 . 0 5 8} \\
(<.000)\end{array}$ & $\begin{array}{l}\mathbf{- 0 . 9 6 4} \\
(0.018)\end{array}$ & $\begin{array}{c}1.656 \\
(0.752)\end{array}$ & $\begin{array}{c}0.020 \\
(0.993)\end{array}$ & $\begin{array}{l}71.521 \\
(0.120)\end{array}$ & $\begin{array}{c}-47.219 \\
(0.006)\end{array}$ \\
\hline & $\begin{array}{l}\text { Adj. } R^{2} \\
=0.382 \\
F=15.9\end{array}$ & $\begin{array}{l}\text { Adj. } R^{2} \\
=0.259 \\
F=9.4\end{array}$ & $\begin{array}{l}\text { Adj. } \mathrm{R}^{2} \\
=0.411 \\
\mathrm{~F}=18.9\end{array}$ & $\begin{array}{c}\text { Adj. } R^{2} \\
=0.207 \\
F=7.7\end{array}$ & $\begin{array}{l}\text { Adj. } R^{2} \\
=0.306 \\
F=2.3\end{array}$ & $\begin{array}{c}\text { Adj. } R^{2} \\
=0.497 \\
F=3.9\end{array}$ & $\begin{array}{l}\text { Adj. } R^{2} \\
=0.841 \\
F=10.3\end{array}$ & $\begin{array}{c}\text { Adj. } R^{2} \\
=0.403 \\
F=2.2\end{array}$ \\
\hline & $n=290$ & $\mathrm{n}=290$ & $n=309$ & $\mathrm{n}=309$ & $\mathrm{n}=36$ & $\mathrm{n}=36$ & $\mathrm{n}=22$ & $\mathrm{n}=22$ \\
\hline
\end{tabular}




\section{Table 8}

\section{Relationship of Financial Performance Measured by Tobin's $q$ Ratio and Market-Value Inefficiency to Investment Strategy and Small Business Lending}

The data set includes 267 publicly traded, top-tier bank holding companies at the end of 2013. Small community banks have consolidated assets less than $\$ 1$ billion, large community banks have consolidated assets from $\$ 1$ billion up to $\$ 10$ billion, and midsize banks have assets between $\$ 10$ billion and $\$ 50$ billion. Large banks have assets between $\$ 50$ billion and $\$ 250$ billion and the largest banks have assets exceeding $\$ 250$ billion, which we group together because their numbers are small. Market-value inefficiency is given by the stochastic frontier of the market value of assets as a function of the book value of assets and is the difference between the highest potential market value and the achieved market value adjusted for noise as a proportion of the highest potential value. Regressions are estimated with OLS, and standard errors are heteroscedasticity consistent. Parameter estimates in bold are significantly different from zero at stricter than $10 \%$.

\begin{tabular}{|c|c|c|c|c|c|c|c|c|}
\hline \multirow{4}{*}{ Variable } & \multicolumn{8}{|c|}{ Dependent Variable by Size Group } \\
\hline & \multicolumn{2}{|c|}{$\begin{array}{c}\text { Small Community } \\
\text { Banks }\end{array}$} & \multicolumn{2}{|c|}{$\begin{array}{c}\text { Large Community } \\
\text { Banks }\end{array}$} & \multicolumn{2}{|c|}{ Midsize Banks } & \multicolumn{2}{|c|}{$\begin{array}{c}\text { Large and Largest } \\
\text { Banks }\end{array}$} \\
\hline & $\begin{array}{l}\text { Tobin's } q \\
\text { Ratio }\end{array}$ & $\begin{array}{c}\text { Market } \\
\text { Value } \\
\text { Inefficiency }\end{array}$ & $\begin{array}{l}\text { Tobin's } q \\
\text { Ratio }\end{array}$ & $\begin{array}{c}\text { Market } \\
\text { Value } \\
\text { Inefficiency }\end{array}$ & $\begin{array}{l}\text { Tobin's } q \\
\text { Ratio }\end{array}$ & $\begin{array}{c}\text { Market } \\
\text { Value } \\
\text { Inefficiency }\end{array}$ & $\begin{array}{l}\text { Tobin's } q \\
\text { Ratio }\end{array}$ & $\begin{array}{c}\text { Market } \\
\text { Value } \\
\text { Inefficiency }\end{array}$ \\
\hline & $\begin{array}{l}\text { Parameter } \\
\text { Estimate } \\
(\mathrm{Pr}>|\mathrm{t}|)\end{array}$ & $\begin{array}{l}\text { Parameter } \\
\text { Estimate } \\
(\mathrm{Pr}>|\mathrm{t}|)\end{array}$ & $\begin{array}{l}\text { Parameter } \\
\text { Estimate } \\
(\operatorname{Pr}>|t|)\end{array}$ & $\begin{array}{l}\text { Parameter } \\
\text { Estimate } \\
(\operatorname{Pr}>|t|)\end{array}$ & $\begin{array}{l}\text { Parameter } \\
\text { Estimate } \\
(\operatorname{Pr}>|t|)\end{array}$ & $\begin{array}{l}\text { Parameter } \\
\text { Estimate } \\
(\mathrm{Pr}>|\mathrm{t}|)\end{array}$ & $\begin{array}{l}\text { Parameter } \\
\text { Estimate } \\
(\operatorname{Pr}>|t|)\end{array}$ & $\begin{array}{c}\text { Parameter } \\
\text { Estimate } \\
(\operatorname{Pr}>|t|)\end{array}$ \\
\hline Intercept & $\begin{array}{l}-1.642 \\
(0.244)\end{array}$ & $\begin{array}{c}\mathbf{4 . 5 0 0} \\
(<.000)\end{array}$ & $\begin{array}{c}1.335 \\
(<0.000)\end{array}$ & $\begin{array}{l}1.629 \\
(<.000)\end{array}$ & $\begin{array}{c}2.067 \\
(<0.000)\end{array}$ & $\begin{array}{l}-0.259 \\
(0.288)\end{array}$ & $\begin{array}{l}-\mathbf{0 . 5 5 9} \\
(0.650)\end{array}$ & $\begin{array}{c}1.666 \\
(0.122)\end{array}$ \\
\hline $\begin{array}{l}\text { Investment } \\
\text { Opportunity } \\
\text { Ratio }\end{array}$ & $\begin{array}{c}0.229 \\
(0.115)\end{array}$ & $\begin{array}{l}-0.055 \\
(0.151)\end{array}$ & $\begin{array}{l}-0.231 \\
(0.020)\end{array}$ & $\begin{array}{c}\mathbf{0 . 2 8 5} \\
(<.000)\end{array}$ & $\begin{array}{l}-0.112 \\
(0.519)\end{array}$ & $\begin{array}{c}0.072 \\
(0.573)\end{array}$ & $\begin{array}{l}-0.133 \\
(0.679\end{array}$ & $\begin{array}{c}0.097 \\
(0.758)\end{array}$ \\
\hline $\begin{array}{l}\text { log (Book Value } \\
\text { Assets }(1,000 \mathrm{~s}) \text { ) }\end{array}$ & $\begin{array}{c}\mathbf{0 . 1 4 0} \\
(0.078)\end{array}$ & $\begin{array}{l}\mathbf{- 0 . 2 8 0} \\
(<.000)\end{array}$ & $\begin{array}{c}0.010 \\
(0.506)\end{array}$ & $\begin{array}{l}-\mathbf{- 0 . 1 2 3} \\
(<.000)\end{array}$ & $\begin{array}{l}-\mathbf{0 . 0 4 4} \\
(0.007)\end{array}$ & $\begin{array}{c}0.010 \\
(0.404)\end{array}$ & $\begin{array}{c}0.038 \\
(0.291)\end{array}$ & $\begin{array}{l}-\mathbf{- 0 . 0 5 4} \\
(0.083)\end{array}$ \\
\hline $\begin{array}{l}\text { Total } \\
\text { Loans/Assets }\end{array}$ & $\begin{array}{c}0.210 \\
(0.456)\end{array}$ & $\begin{array}{l}-0.079 \\
(0.315)\end{array}$ & $\begin{array}{l}-0.091 \\
(0.355)\end{array}$ & $\begin{array}{c}0.006 \\
(0.880)\end{array}$ & $\begin{array}{l}-\mathbf{0 . 1 6 1} \\
(0.009)\end{array}$ & $\begin{array}{c}\mathbf{0 . 1 1 4} \\
(0.013)\end{array}$ & $\begin{array}{c}0.111 \\
(0.654)\end{array}$ & $\begin{array}{l}-0.356 \\
(0.168)\end{array}$ \\
\hline $\begin{array}{l}\text { Residential RE } \\
\text { Loans/Assets }\end{array}$ & $\begin{array}{c}0.059 \\
(0.851)\end{array}$ & $\begin{array}{l}-0.016 \\
(0.85)\end{array}$ & $\begin{array}{l}-0.120 \\
(0.366)\end{array}$ & $\begin{array}{c}0.087 \\
(0.152)\end{array}$ & $\begin{array}{l}-0.076 \\
(0.506)\end{array}$ & $\begin{array}{c}0.028 \\
(0.7997)\end{array}$ & $\begin{array}{c}0.753 \\
(0.156)\end{array}$ & $\begin{array}{c}-0246 \\
(0.568)\end{array}$ \\
\hline $\begin{array}{l}\text { Commercial RE } \\
\text { Loans/Assets }\end{array}$ & $\begin{array}{c}0.026 \\
(0.931)\end{array}$ & $\begin{array}{l}-0.009 \\
(0.906)\end{array}$ & $\begin{array}{l}-0.042 \\
(0.702)\end{array}$ & $\begin{array}{c}0.052 \\
(0.313)\end{array}$ & $\begin{array}{l}-\mathbf{0 . 1 5 2} \\
(0.129)\end{array}$ & $\begin{array}{c}0.084 \\
(0.231)\end{array}$ & $\begin{array}{c}\mathbf{0 . 5 8 2} \\
(0.085)\end{array}$ & $\begin{array}{l}-0.261 \\
(0.375)\end{array}$ \\
\hline $\begin{array}{l}\text { Consumer } \\
\text { Loans/Assets }\end{array}$ & $\begin{array}{c}0.030 \\
(0.922)\end{array}$ & $\begin{array}{l}-0.023 \\
(0.779)\end{array}$ & $\begin{array}{l}-0.063 \\
(0.624)\end{array}$ & $\begin{array}{c}0.045 \\
(0.448)\end{array}$ & $\begin{array}{c}0.030 \\
(0.872)\end{array}$ & $\begin{array}{l}-0.099 \\
(0.462)\end{array}$ & $\begin{array}{l}0.963 \\
0.050\end{array}$ & $\begin{array}{l}-0.456 \\
(0.227)\end{array}$ \\
\hline $\begin{array}{l}\text { Total Business } \\
\text { Loans/Assets }\end{array}$ & $\begin{array}{c}0.207 \\
(0.589)\end{array}$ & $\begin{array}{l}-0.069 \\
(0.508)\end{array}$ & $\begin{array}{l}-\mathbf{- 0 . 2 5 1} \\
(0.078)\end{array}$ & $\begin{array}{c}\mathbf{0 . 1 5 3} \\
(0.041)\end{array}$ & $\begin{array}{l}-0.046 \\
(0.690)\end{array}$ & $\begin{array}{l}-0.003 \\
(0.969)\end{array}$ & $\begin{array}{c}0.677 \\
(0.134)\end{array}$ & $\begin{array}{l}-0.262 \\
(0.485)\end{array}$ \\
\hline $\begin{array}{l}\text { Small Business } \\
\text { Loans/Assets }\end{array}$ & $\begin{array}{l}-0.260 \\
(0.023) \\
\end{array}$ & $\begin{array}{c}\mathbf{0 . 0 9 8} \\
(0.025)\end{array}$ & $\begin{array}{c}\mathbf{0 . 3 6 0} \\
(0.014)\end{array}$ & $\begin{array}{l}-0.137 \\
(0.127)\end{array}$ & $\begin{array}{l}-0.166 \\
(0.342)\end{array}$ & $\begin{array}{c}0.160 \\
(0.299)\end{array}$ & $\begin{array}{c}4.844 \\
(0.178)\end{array}$ & $\begin{array}{l}-3.409 \\
(0.216)\end{array}$ \\
\hline $\begin{array}{l}\text { Liquid } \\
\text { Assets/Assets }\end{array}$ & $\begin{array}{c}0.256 \\
(0.235) \\
\end{array}$ & $\begin{array}{l}-0.091 \\
(0.142) \\
\end{array}$ & $\begin{array}{l}-0.137 \\
(0.287) \\
\end{array}$ & $\begin{array}{c}0.088 \\
(0.145) \\
\end{array}$ & $\begin{array}{l}-\mathbf{0 . 1 4 7} \\
(0.088) \\
\end{array}$ & $\begin{array}{c}0.091 \\
(0.144) \\
\end{array}$ & $\begin{array}{c}\mathbf{0 . 6 5 8} \\
(0.025) \\
\end{array}$ & $\begin{array}{c}-0.466 \\
(0.0055) \\
\end{array}$ \\
\hline $\begin{array}{l}\text { Noninterest } \\
\text { Income/ } \\
\text { Revenue }\end{array}$ & $\begin{array}{c}\mathbf{0 . 1 1 8} \\
(0.005)\end{array}$ & $\begin{array}{l}-\mathbf{0 . 0 4 0} \\
(0.012)\end{array}$ & $\begin{array}{c}0.017 \\
(0.394)\end{array}$ & $\begin{array}{c}0.005 \\
(0.758)\end{array}$ & $\begin{array}{l}-\mathbf{0 . 1 3 6} \\
(0.016)\end{array}$ & $\begin{array}{c}\mathbf{0 . 0 9 1} \\
(0.031)\end{array}$ & $\begin{array}{c}\mathbf{0 . 5 0 2} \\
(0.009)\end{array}$ & $\begin{array}{l}-\mathbf{0 . 3 4 3} \\
(0.025)\end{array}$ \\
\hline $\begin{array}{l}\text { Nonperforming } \\
\text { Loans/Assets }\end{array}$ & $\begin{array}{l}-\mathbf{- 0 . 7 0 8} \\
(0.005)\end{array}$ & $\begin{array}{c}\mathbf{0 . 2 1 0} \\
(0.005)\end{array}$ & $\begin{array}{l}-\mathbf{0 . 6 6 7} \\
(0.005)\end{array}$ & $\begin{array}{c}\mathbf{0 . 5 3 1} \\
(0.002) \\
\end{array}$ & $\begin{array}{l}-1.101 \\
(<.000)\end{array}$ & $\begin{array}{c}\mathbf{0 . 9 2 7} \\
(<.000)\end{array}$ & $\begin{array}{c}-3.514 \\
(0.205)\end{array}$ & $\begin{array}{c}2.233 \\
(0.317)\end{array}$ \\
\hline $\begin{array}{l}\text { Deposits/(Depos } \\
\text { its + Other } \\
\text { Borrowed } \\
\text { Funds) }\end{array}$ & $\begin{array}{c}\mathbf{0 . 1 1 5} \\
(0.035)\end{array}$ & $\begin{array}{l}-\mathbf{0 . 0 3 1} \\
(0.074)\end{array}$ & $\begin{array}{c}0.025 \\
(0.679)\end{array}$ & $\begin{array}{l}-0.045 \\
(0.188)\end{array}$ & $\begin{array}{c}\mathbf{0 . 1 4 3} \\
(0.025)\end{array}$ & $\begin{array}{l}-\mathbf{0 . 0 9 4} \\
(0.027)\end{array}$ & $\begin{array}{c}-0.178 \\
(0.193)\end{array}$ & $\begin{array}{c}0.114 \\
(0.271)\end{array}$ \\
\hline $\begin{array}{l}\text { (Equity + Sub } \\
\text { Debt + Loan Loss } \\
\text { Reserves)/ } \\
\text { Assets }\end{array}$ & $\begin{array}{c}0.165 \\
(0.372)\end{array}$ & $\begin{array}{l}-0.016 \\
(0.768)\end{array}$ & $\begin{array}{c}0.217 \\
(0.258)\end{array}$ & $\begin{array}{c}0.038 \\
(0.678)\end{array}$ & $\begin{array}{c}0.050 \\
(0.824)\end{array}$ & $\begin{array}{c}0.080 \\
(0.578)\end{array}$ & $\begin{array}{c}2.316 \\
(0.118)\end{array}$ & $\begin{array}{l}-0.915 \\
(0.476)\end{array}$ \\
\hline
\end{tabular}


Table 8 continued

\section{Relationship of Financial Performance Measured by Tobin's $q$ Ratio and Market-Value Inefficiency to Investment Strategy and Small Business Lending}

\begin{tabular}{|c|c|c|c|c|c|c|c|c|}
\hline \multirow{4}{*}{ Variable } & \multicolumn{8}{|c|}{ Dependent Variable by Size Group } \\
\hline & \multicolumn{2}{|c|}{$\begin{array}{c}\text { Small Community } \\
\text { Banks }\end{array}$} & \multicolumn{2}{|c|}{$\begin{array}{c}\text { Large Community } \\
\text { Banks }\end{array}$} & \multicolumn{2}{|c|}{ Midsize Banks } & \multicolumn{2}{|c|}{$\begin{array}{c}\text { Large and Largest } \\
\text { Banks }\end{array}$} \\
\hline & $\begin{array}{l}\text { Tobin's } q \\
\text { Ratio }\end{array}$ & $\begin{array}{c}\text { Market } \\
\text { Value } \\
\text { Inefficiency }\end{array}$ & $\begin{array}{l}\text { Tobin's } q \\
\text { Ratio }\end{array}$ & $\begin{array}{c}\text { Market } \\
\text { Value } \\
\text { Inefficiency }\end{array}$ & $\begin{array}{l}\text { Tobin's } q \\
\text { Ratio }\end{array}$ & $\begin{array}{c}\text { Market } \\
\text { Value } \\
\text { Inefficiency }\end{array}$ & $\begin{array}{l}\text { Tobin's } q \\
\text { Ratio }\end{array}$ & $\begin{array}{c}\text { Market } \\
\text { Value } \\
\text { Inefficiency }\end{array}$ \\
\hline & $\begin{array}{c}\text { Parameter } \\
\text { Estimate } \\
(\operatorname{Pr}>|t|) \\
\end{array}$ & $\begin{array}{c}\text { Parameter } \\
\text { Estimate } \\
(\operatorname{Pr}>|t|) \\
\end{array}$ & $\begin{array}{c}\text { Parameter } \\
\text { Estimate } \\
(\operatorname{Pr}>|t|) \\
\end{array}$ & $\begin{array}{l}\text { Parameter } \\
\text { Estimate } \\
(\operatorname{Pr}>|t|) \\
\end{array}$ & $\begin{array}{l}\text { Parameter } \\
\text { Estimate } \\
(\operatorname{Pr}>|t|) \\
\end{array}$ & $\begin{array}{c}\text { Parameter } \\
\text { Estimate } \\
(\operatorname{Pr}>|t|) \\
\end{array}$ & $\begin{array}{c}\text { Paramete } \\
\text { r Estimate } \\
(\operatorname{Pr}>|t|)\end{array}$ & $\begin{array}{l}\text { Parameter } \\
\text { Estimate } \\
(\operatorname{Pr}>|t|) \\
\end{array}$ \\
\hline $\begin{array}{l}+1 \% \text { in Business Loans } \\
+1 \% \text { in Small Business } \\
\text { Loans }\end{array}$ & $\begin{array}{l}-0.053 \\
(0.885)\end{array}$ & $\begin{array}{c}0.028 \\
(0.771)\end{array}$ & $\begin{array}{c}0.109 \\
(0.592)\end{array}$ & $\begin{array}{c}0.016 \\
(0.870)\end{array}$ & $\begin{array}{l}-0.212 \\
(0.233)\end{array}$ & $\begin{array}{c}0.156 \\
(0.312)\end{array}$ & $\begin{array}{c}5.521 \\
(0.127)\end{array}$ & $\begin{array}{c}-3.671 \\
(0.191)\end{array}$ \\
\hline $\begin{array}{l}+1 \% \text { in Total Loans and } \\
+1 \% \text { in Business Loans }\end{array}$ & $\begin{array}{c}\mathbf{0 . 4 1 7} \\
(0.066)\end{array}$ & $\begin{array}{l}-\mathbf{0 . 1 4 8} \\
(0.024)\end{array}$ & $\begin{array}{l}-\mathbf{0 . 3 4 2} \\
(0.009)\end{array}$ & $\begin{array}{c}\mathbf{0 . 1 5 9} \\
(0.029) \\
\end{array}$ & $\begin{array}{l}-0.208 \\
(0.052)\end{array}$ & $\begin{array}{c}0.110 \\
(0.143) \\
\end{array}$ & $\begin{array}{c}\mathbf{0 . 7 8 8} \\
(0.013) \\
\end{array}$ & $\begin{array}{l}\mathbf{- 0 . 6 1 7} \\
(0.012)\end{array}$ \\
\hline $\begin{array}{l}+1 \% \text { in Total Loans, } \\
+1 \% \text { in Business Loans } \\
+1 \% \text { in Small Business } \\
\text { Loans }\end{array}$ & $\begin{array}{c}0.157 \\
(0.387)\end{array}$ & $\begin{array}{l}-0.050 \\
(0.297)\end{array}$ & $\begin{array}{c}0.019 \\
(0.923)\end{array}$ & $\begin{array}{c}0.022 \\
(0.823)\end{array}$ & $\begin{array}{l}-\mathbf{0 . 3 7 4} \\
(0.032)\end{array}$ & $\begin{array}{c}\mathbf{0 . 2 7 0} \\
(0.073)\end{array}$ & $\begin{array}{c}5.632 \\
(0.115)\end{array}$ & $\begin{array}{l}-4.027 \\
(0.244)\end{array}$ \\
\hline $\begin{array}{l}+1 \% \text { in Business Loans } \\
-1 \% \text { in Small Business } \\
\text { Loans }\end{array}$ & $\begin{array}{c}0.467 \\
(0.270)\end{array}$ & $\begin{array}{l}-0.167 \\
(0.181)\end{array}$ & & & & & & \\
\hline $\begin{array}{l}-1 \% \text { in Business Loans } \\
+1 \% \text { in Small Business } \\
\text { Loans }\end{array}$ & & & $\begin{array}{c}\mathbf{0 . 6 1 2} \\
(0.002)\end{array}$ & $\begin{array}{l}-\mathbf{0 . 2 9 0} \\
(0.027) \\
\end{array}$ & & & & \\
\hline $\begin{array}{l}-1 \% \text { in Business Loans } \\
-1 \% \text { in Small Business } \\
\text { Loans }\end{array}$ & & & & & $\begin{array}{c}0.212 \\
(0.233) \\
\end{array}$ & $\begin{array}{l}-0.156 \\
(0.312)\end{array}$ & & \\
\hline $\begin{array}{l}-1 \% \text { in Total Loans and } \\
-1 \% \text { in Business Loans }\end{array}$ & & & $\begin{array}{c}0.342 \\
(0.009)\end{array}$ & $\begin{array}{l}-0.159 \\
(0.029)\end{array}$ & & & & \\
\hline $\begin{array}{l}-1 \% \text { in Total Loans, } \\
-1 \% \text { in Business Loans } \\
-1 \% \text { in Small Business } \\
\text { Loans }\end{array}$ & & & & & $\begin{array}{c}\mathbf{0 . 3 7 4} \\
(0.032)\end{array}$ & $\begin{array}{l}-\mathbf{0 . 2 7 0} \\
(0.073)\end{array}$ & & \\
\hline $\begin{array}{l}+1 \% \text { in Total Loans, } \\
+1 \% \text { in Business Loans } \\
-1 \% \text { in Small Business } \\
\text { Loans }\end{array}$ & $\begin{array}{c}\mathbf{0 . 6 7 7} \\
(0.027)\end{array}$ & $\begin{array}{l}-\mathbf{0 . 2 4 6} \\
(0.013)\end{array}$ & & & & & & \\
\hline $\begin{array}{l}-1 \% \text { in Total Loans, } \\
-1 \% \text { in Business Loans } \\
+1 \% \text { in Small Business } \\
\text { Loans }\end{array}$ & & & $\begin{array}{c}\mathbf{0 . 7 0 2} \\
(<0.000)\end{array}$ & $\begin{array}{l}-\mathbf{0 . 3 0 0} \\
(0.024)\end{array}$ & & & & \\
\hline $\begin{array}{l}-1 \% \text { in Total Loans, } \\
-1 \% \text { in Commercial Real } \\
\text { Estate }\end{array}$ & & & & & $\begin{array}{c}\mathbf{0 . 3 1 4} \\
(0.011)\end{array}$ & $\begin{array}{l}-\mathbf{0 . 1 9 8} \\
(0.019)\end{array}$ & & \\
\hline & $\begin{array}{l}\text { Adj. } R^{2} \\
=0.267 \\
F=2.48\end{array}$ & $\begin{array}{l}\text { Adj. } R^{2} \\
=0.980 \\
F=205.4\end{array}$ & $\begin{array}{c}\text { Adj. } R^{2} \\
=0.393 \\
F=8.7\end{array}$ & $\begin{array}{c}\text { Adj. } \mathrm{R}^{2} \\
=0.954 \\
\mathrm{~F}=246.7\end{array}$ & $\begin{array}{c}\text { Adj. } R^{2} \\
=0.678 \\
F=6.5\end{array}$ & $\begin{array}{c}\text { Adj. } R^{2} \\
=0.650 \\
F=5.9\end{array}$ & $\begin{array}{l}\text { Adj. } R^{2} \\
=0.750 \\
F=5.83\end{array}$ & $\begin{array}{l}\text { Adj. } R^{2} \\
=0.647 \\
F=3.96\end{array}$ \\
\hline & $\mathrm{n}=54$ & $\mathrm{n}=54$ & $n=156$ & $n=156$ & $\mathrm{n}=35$ & $\mathrm{n}=35$ & $\mathrm{n}=22$ & $n=22$ \\
\hline
\end{tabular}




\section{Appendix A}

\section{Performance Frontier Estimations}

\section{Table A1}

\section{Stochastic Frontier Estimation}

\section{Potential Return on Assets (ROA) and ROA Inefficiency}

The data set includes 761 top-tier bank holding companies at the end of 2013 with five years of data (2009-2013) needed to compute the standard deviation of ROA, a proxy for ROA risk. ROA is defined as net income (loss) before income taxes and extraordinary items divided by consolidated assets. In the Y9-C regulatory report, the former is given by the category, BHCK4301, and the latter, by BHCK2170. The frontier estimates the highest potential ROA and the ROA inefficiency as the difference between potential ROA and the noise-adjusted observed ROA. Compared to the normalhalf-normal model, the normal-exponential model with a constant term is the best by AIC (BIC) and Vuong's test for relative explanatory power.

\begin{tabular}{|c|l|c|c|}
\hline Parameter & \multicolumn{1}{|c|}{ Variable } & $\begin{array}{c}\text { Coefficient } \\
\text { Estimate }\end{array}$ & $\operatorname{Pr}(>|\mathbf{t}|)$ \\
\hline$\beta_{0}$ & Intercept & $\mathbf{1 . 5 6 2 5 5 5}$ & 0.000000 \\
\hline$\beta_{1}$ & Standard Deviation of $\mathrm{ROA}_{\mathrm{i}}$ & $\mathbf{- 3 . 9 1 2 1 7 2}$ & 0.000476 \\
\hline$\beta_{2}$ & $\begin{array}{l}\left(\text { Standard Deviation of } \mathrm{ROA}_{\mathrm{i}}\right)(\ln (\text { Boook Value of Assets less } \\
\left.\text { Goodwill } \mathrm{i}_{\mathrm{i}}\right)\end{array}$ & $\mathbf{0 . 2 6 3 8 5 6}$ & 0.000471 \\
\hline$\beta_{3}$ & $\left(\text { Standard Deviation of } \mathrm{ROA}_{\mathrm{i}}\right)^{2}$ & $\mathbf{1 . 1 5 1 0 2 9}$ & 0.026828 \\
\hline$\beta_{4}$ & $\begin{array}{l}\left(\left(\text { Standard Deviation of } \mathrm{ROA}_{\mathrm{i}}\right)^{2}\right)(\ln (\text { Book Value of Assets } \\
\left.\text { less Goodwill } \mathrm{i}_{\mathrm{i}}\right)\end{array}$ & $\mathbf{- 0 . 0 7 8 0 7 8}$ & 0.020840 \\
\hline$\sigma_{\mu}=1 / \theta$ & & $\mathbf{0 . 4 7 2 7 1 4}$ & 0.000000 \\
\hline$\sigma_{v}$ & & $\mathbf{0 . 6 5 7 4 7 4}$ & 0.000000 \\
\hline
\end{tabular}




\section{Table A2}

\section{Stochastic Frontier Estimation}

\section{Potential Return on Assets (ROA) and ROA Inefficiency Conditioned on ROA Risk and the Investment Strategy}

The data set includes 761 top-tier bank holding companies at the end of 2013 with five years of data (2009-2013) needed to compute the standard deviation of ROA, a proxy for ROA risk. ROA is defined as net income (loss) before income taxes and extraordinary items divided by consolidated assets. In the Y9-C regulatory report, the former is given by the category, BHCK4301, and the latter, by BHCK2170. Liquid assets are defined as the sum of cash, balances at other financial institutions, federal funds sold, securities, and securities sold under agreement to repurchase. Taking into account the investment strategy as well as risk and asset size, the frontier estimates the highest potential ROA and the ROA inefficiency as the difference between potential ROA and the noise-adjusted observed ROA. Compared to the normal-half-normal model, the normal-exponential model with a constant term is the best by AIC (BIC) and Vuong's test for relative explanatory power. In addition, these tests favor the characterization of investment strategy by the ratio of loans to assets rather than a decomposition of loans into their important components.

\begin{tabular}{|c|l|c|c|}
\hline Parameter & \multicolumn{1}{|c|}{ Variable } & $\begin{array}{c}\text { Coefficient } \\
\text { Estimate }\end{array}$ & Pr $(>|\mathbf{t}|)$ \\
\hline$\beta_{0}$ & Intercept & $\mathbf{1 . 5 6 2 5 5 5}$ & 0.000000 \\
\hline$\beta_{1}$ & Standard Deviation of $\mathrm{ROA}_{\mathrm{i}}$ & $\mathbf{- 3 . 9 1 2 1 7 2}$ & 0.000476 \\
\hline$\beta_{2}$ & $\begin{array}{l}\left(\text { Standard Deviation of } \mathrm{ROA}_{\mathrm{i}}\right)(\ln (\text { Book Value of Assets less } \\
\text { Goodwill } \mathrm{i}_{\mathrm{i}}\end{array}$ & $\mathbf{0 . 2 6 3 8 5 6}$ & 0.000471 \\
\hline$\beta_{3}$ & $\left(\text { Standard Deviation of } \mathrm{ROA}_{\mathrm{i}}\right)^{2}$ & $\mathbf{1 . 1 5 1 0 2 9}$ & 0.026828 \\
\hline$\beta_{4}$ & $\begin{array}{l}\left(\left(\text { Standard Deviation of ROA } \mathrm{i}_{\mathrm{i}}\right)^{2}\right)(\ln (\text { Book Value of Assets } \\
\text { less Goodwill })\end{array}$ & $\mathbf{- 0 . 0 7 8 0 7 8}$ & 0.020840 \\
\hline$\beta_{5}$ & Total Loans/Total Assets & $\mathbf{6 . 2 9 6 4 9 9}$ & 0.000000 \\
\hline$\beta_{6}$ & Liquid Assets/Total Assets & $\mathbf{5 . 5 5 7 9 4 3}$ & 0.000001 \\
\hline$\beta_{7}$ & Noninterest Expense/Total Revenue & $\mathbf{1 . 8 4 4 5 1 8}$ & 0.000000 \\
\hline$\beta_{8}$ & Deposits/(Deposits + Other Borrowed Funds) & $\mathbf{- 0 . 4 1 6 7 6 0}$ & 0.197080 \\
\hline$\beta_{9}$ & (Equity + Sub Debt + Loan Loss Reserves)/ Total Assets & $\mathbf{1 0 . 2 3 5 1 5 0}$ & 0.000000 \\
\hline$\sigma_{\mu}=1 / \theta$ & & $\mathbf{0 . 4 7 2 7 1 4}$ & 0.000000 \\
\hline$\sigma_{v}$ & & $\mathbf{0 . 6 5 7 4 7 4}$ & 0.000000 \\
\hline
\end{tabular}




\section{Table A3}

\section{Stochastic Frontier Estimation}

\section{Potential Market Value of Assets and Market-Value Inefficiency}

The data set includes 353 publicly traded, top-tier bank holding companies at the end of 2013 . The market value of assets is defined by the sum of the market value of equity and the book value of assets less goodwill. The frontier estimates the highest potential value of assets across all potential markets in which the bank could operate. Compared to the normal-half-normal model, the normal-exponential model with a constant term is the best by AIC (BIC) and Vuong's test for relative explanatory power.

\begin{tabular}{|c|l|c|c|}
\hline Parameter & \multicolumn{1}{|c|}{ Variable } & $\begin{array}{c}\text { Coefficient } \\
\text { Estimate }\end{array}$ & $\operatorname{Pr}(>|\mathbf{t}|)$ \\
\hline$\beta_{0}$ & Intercept & $\mathbf{0 . 0 0 6 6 8 3}$ & 0.002036 \\
\hline$\beta_{1}$ & Book Value of Assets less Goodwill $\mathrm{i}$ (in $\$ 100$ Billions) & $\mathbf{1 . 1 2 9 0 1 9}$ & 0.000000 \\
\hline$\beta_{2}$ & ${\left.\text { (Book Value of Assets less Goodwill }{ }_{\mathrm{i}}\right)^{2}(\text { in } \$ 100 \text { Billions) }}$ & $\mathbf{- 0 . 0 0 4 4 5 5}$ & 0.000000 \\
\hline$\sigma_{\mu}=1 / \theta$ & & $\mathbf{0 . 0 2 3 4 3 3}$ & 0.000154 \\
\hline$\sigma_{v}$ & & $\mathbf{0 . 0 0 5 7 3 5}$ & 0.000230 \\
\hline
\end{tabular}

\section{Table A4}

\section{Stochastic Frontier Estimation}

\section{Potential Value of Investment Opportunities}

The data set includes 303 publicly traded, top-tier bank holding companies at the end of 2013 with data on the weighted 10-year average GDP growth rate and the Herfindahl index of concentration in the state banking markets in which it operates where the weights are the proportion of total deposits located in each state market. The frontier estimates the highest potential market value of assets given the states in which the bank operates. Compared to the normal-half-normal model, the normalexponential model with a constant term is the best by AIC (BIC) and Vuong's test for relative explanatory power.

\begin{tabular}{|c|c|c|c|}
\hline Parameter & Variable & $\begin{array}{l}\text { Coefficient } \\
\text { Estimate }\end{array}$ & $\operatorname{Pr}(>|t|)$ \\
\hline$\beta_{0}$ & Intercept & 0.003670 & 0.000024 \\
\hline$\beta_{1}$ & 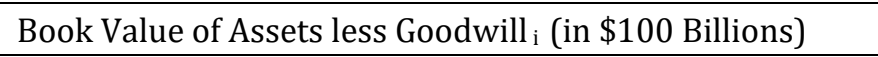 & 1.357367 & 0.000000 \\
\hline$\beta_{2}$ & $\left(\text { Book Value of Assets less Goodwill }{ }_{i}\right)^{2}$ (in $\$ 100$ Billions) & -0.006434 & 0.000000 \\
\hline$\beta_{3}$ & $\begin{array}{l}\left.\text { (GDP Growth Rate }{ }_{\mathrm{i}}\right)(\text { Book Value of Assets less Goodwill } \\
(100 \text { Billions }) \text { ) }\end{array}$ & -0.039423 & 0.001216 \\
\hline$\beta_{4}$ & 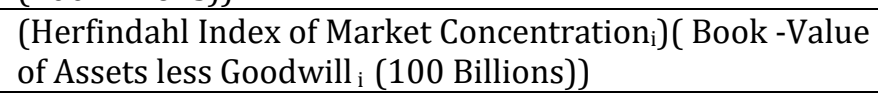 & -0.188177 & 0.000000 \\
\hline$\sigma_{\mu}=1 / \theta$ & & 0.025283 & 0.000001 \\
\hline$\sigma_{v}$ & & 0.002960 & 0.000000 \\
\hline
\end{tabular}




\section{Appendix B \\ The Effectiveness of Banks' Credit Analysis and Monitoring}

\section{B.1. Background}

For each bank-size group, Table 4 compares the ratio of nonperforming loans to total loans. Small community banks experience a rate of 0.037 in contrast to 0.024 for large community banks, 0.022 for midsize banks, 0.019 for large banks, and 0.024 for the largest banks (row 11). What explains the higher rate of nonperformance of the small community banks?

One possibility is that banks with higher levels of nonperforming loans may be electing to lend to riskier borrowers who have a higher expected level of default. Alternatively, the higher level of nonperformance may reflect less effective credit analysis and loan monitoring. Either way, as reported in Tables $\mathbf{7}$ and $\mathbf{8}$, the higher proportion of nonperforming loans is generally associated with worse financial performance.

We apply the analysis of Hughes and Moon (2017) based on stochastic frontier techniques to distinguish between nonperformance because of the degree of effectiveness of credit evaluation and monitoring and nonperformance because of the degree of inherent credit risk. We focus on business loans and commercial real estate (CRE) loans.

\section{B.2. Best-Practice Loan Performance and the Efficiency of Credit Evaluation and Monitoring}

A bank's ratio of nonperforming loans to total loans is a common ex post measure of the riskiness of the bank's loans. On the other hand, the average contractual interest charged on a bank's loans gauges ex ante riskiness because it contains a risk premium that reflects the loan portfolio's average ex ante credit risk, collateral, and maturity structure. Morgan and Ashcraft (2003, p. 181) make this point: “There is strong evidence that the interest rates charged by banks on the flow of newly extended Commercial \& Industrial (C\&I) loans predict future loan performance and CAMEL rating downgrades by bank supervisors." Moreover, the adverse selection that results from charging a higher contractual interest rate on a particular type of loan results in higher credit risk and a higher expected rate of nonperformance. 
Thus, higher expected nonperformance is linked to charging a higher contractual interest rate. For any particular average contractual interest rate, the realized rate of nonperforming loans depends in part on the efficiency of credit evaluation and loan monitoring. For example, if a bank does a poor job of credit evaluation, then for any given contractual interest rate, it will have underestimated the riskiness of its loans and will experience a higher rate of nonperformance for its average contractual interest rate than a bank that accurately evaluates credit risk and lends to better credit risks at the same contractual interest rate. Or, if two banks accurately evaluate credit risk when extending new loans, but one bank does a worse job of monitoring its loans, it will experience worse performance than the other bank. Thus, for any given volume of a particular type of loan and average contractual interest rate charged on it, the rate of nonperforming loans varies in part with the efficiency of credit evaluation and monitoring.

Macroeconomic conditions and market concentration in a bank's lending markets also influence the rate of nonperformance. Petersen and Rajan (1995) provide evidence that the relationship between the contractual interest rate and nonperformance depends on banks' market power in their lending markets. Banks that operate without significant competition from other lenders are able to price initial loans to new businesses at lower-than-competitive rates to reduce the probability of default. As the businesses succeed and become more experienced, the bank can make up revenue lost to the previous lower rate. That is to say, the rate falls but not as much as it would in a more competitive market.

\section{B.3. Specifying and Estimating the Best-Practice Loan Nonperformance Frontier}

We focus on the ratio of nonperforming business loans to total business loans and the ratio of nonperforming CRE loans to total CRE loans. We use stochastic frontier techniques and maximum likelihood estimation to estimate a best-practice (minimum) frontier of the ratio of nonperforming loans to total loans for business and CRE loans. We condition the frontier on the volume of the loan type, the total loan volume, the average contractual interest rate charged on the loan type, and macroeconomic conditions and market concentration in the bank's markets. That is, 


$$
N P_{\mathrm{i}}=\boldsymbol{X} \boldsymbol{\beta}+\varepsilon_{\mathrm{i}}
$$

where $N P_{\mathrm{i}}=$ ratio of nonperforming loans of a given type to total loans of that type at bank $i$,

$\boldsymbol{X}$ is a vector of loan volumes and control variables,

$$
\begin{aligned}
& x_{1}=\text { Total type of } \operatorname{loan}_{\mathrm{i}}(100 \text { billions }) \text {, } \\
& x_{2}=\left(\text { Total type of } \operatorname{loan}_{\mathrm{i}}(100 \text { billions })\right)^{2} \text {, } \\
& X_{3}=\text { Total loans }_{\mathrm{i}}(100 \text { billions }) \text {, } \\
& x_{4}=(\text { Total loans } \mathrm{i}(100 \text { billions }))^{2},
\end{aligned}
$$

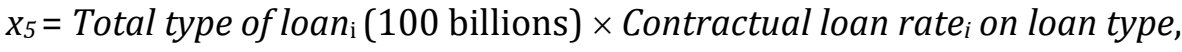

$$
\begin{aligned}
& x_{6}=\text { Total type of } \text { loan }_{\mathrm{i}}(100 \text { billions }) \times \text { GDP growth rate across bank's markets, } \\
& x_{7}=\text { Total type of } \text { loan }_{\mathrm{i}}(100 \text { billions }) \times \text { Herfindahl index of market concentration } \\
& \text { across bank's markets, } \\
& x_{8}=\text { Contractual loan rate } \text { i }_{\mathrm{i}} \text { on loan type } \times \text { Herfindahl index of market concentration } \\
& \text { across bank's markets, }
\end{aligned}
$$

and $\varepsilon_{i}=v_{i}+\mu_{i}$ is a composite error term.

The Herfindahl index of market concentration is a weighted average of concentration in each state in which the bank operates, and the GDP growth rate is a 10-year weighted average state GDP growth rate in the states in which the bank operates. The weights are the ratio of the deposits in the state as a proportion of total deposits across all states. The composite error term, $\varepsilon_{i}=v_{i}+\mu_{i}$, is the sum of a two-sided, normally distributed error term, $v_{i} \sim \operatorname{iid} N\left(0, \sigma_{v}{ }^{2}\right)$, that captures statistical noise, and a term, $\mu_{i}$, distributed exponentially, $\mu_{i}(>0) \sim \theta \exp (-\theta u)$, that gauges the systematic excess nonperforming loan ratio. ${ }^{34}$ The deterministic kernel defines the best-practice (minimum) ratio:

Best-Practice $N P_{i}=X \beta$.

Conditional on the control variables, the best-practice NP represents the expected best practice, i.e., ex post credit risk, were the bank totally efficient at credit evaluation and loan monitoring. So the best-practice NP gauges the bank's inherent credit risk.

34 The AIC (BIC) and Vuong's test for relative explanatory power favor the exponential distribution of the onesided error term over the half-normal distribution and the specification without a constant term. 
Following Jondrow, et al. (1982), we define the bank-specific excess nonperforming loan ratio by the expectation of $\mu_{i}$ conditional on $\varepsilon_{i}$ :

$$
\text { Excess } \boldsymbol{N P}_{i}=E\left(\mu_{i} \mid \varepsilon_{i}\right) \text {. }
$$

Noise is given by the expectation of $v_{i}$ conditional on $\varepsilon_{i}$ :

$$
\text { Noise }_{i}=E\left(v_{i} \mid \varepsilon_{i}\right)=\varepsilon_{i}-E\left(\mu_{i} \mid \varepsilon_{i}\right) .
$$

Noise can be subtracted from the observed nonperforming loan ratio to obtain the noise-adjusted observed nonperforming loan ratio:

Noise-Adjusted $N P_{i}=N P_{i}-E\left(v_{i} \mid \mathcal{E}_{i}\right)$.

Figure B.1 illustrates the deterministic best-practice nonperforming business loans frontier. In this example, bank $i$ has total business loans of $\$ 8$ billion and experiences an achieved nonperforming loan ratio of 0.030 ; its nonperforming loan ratio adjusted for statistical noise, $N P_{\mathrm{i}}-$ $v_{i}$, equals 0.025 . Measured as the difference between the noise-adjusted observed ratio of 0.025 and the best-practice minimum of 0.010 , the excess nonperforming loans ratio equals 0.015 , the difference between the noise-adjusted observed ratio and the best-practice minimum. Alternatively, the excess ratio can be expressed as the difference between the achieved ratio of 0.030 and the stochastic frontier ratio of 0.015 . (The stochastic frontier ratio is the best-practice minimum adjusted for noise, $0.010+0.005=0.015$.)

The estimated Equation (A1) provides a useful decomposition of the observed nonperforming loans ratio into a minimum nonperforming loans ratio that reflects inherent credit risk, the excess ratio that reflects inefficiency at evaluating credit risk and monitoring loans, and noise:

$$
\begin{aligned}
& N P_{i}=\text { Best-Practice } N_{P_{i}}+\text { Excess }_{N P_{i}}+\text { Noise }_{i} \\
& =\text { Inherent Credit Risk } \boldsymbol{i}_{i}+\text { Inefficiency }_{i}+\text { Luck }_{i} \\
& =\boldsymbol{X} \bullet \boldsymbol{\beta}+E\left(\mu_{i} \mid \varepsilon_{i}\right)+E\left(v_{i} \mid \varepsilon_{i}\right)
\end{aligned}
$$

The frontier specified in Equation (A1) is estimated for business loans and commercial real estate (CRE) loans. The parameters of each loan type are provided in Table A1 and Table A2. 
Based on robust standard errors, parameter estimates significantly different from zero at the 10 percent or stricter level are in bold. The statistically significant parameter estimates appear to be sensible. The negative coefficients, $\beta_{1}$, on the first-order effects of the volume of business loans and of CRE loans suggests that an increase in the scale of these types of lending is related to better bestpractice performance. In the CRE fitted frontier, the negative coefficient, $\beta_{6}$, on the GDP growth rate indicates that better macroeconomic conditions in local lending markets improve best-practice nonperformance for CRE lending. The positive coefficient, $\beta_{5}$, on the CRE contractual interest rate indicates that higher loan rates are associated with riskier borrowers and higher best-practice nonperforming loan rates.

For each of the five size groups and the two types of loans, we report the decomposition of the mean observed nonperforming loans ratio into its mean inherent credit risk and its mean excess nonperforming loan ratio. As noted in Equation (A6), the sum of the inherent credit risk, the excess nonperforming loans ratio, and the noise equals the observed nonperforming loans ratio. We report the values of the first two components in Table 5 for commercial and industrial loans and in Table 6 for commercial real estate loans. 


\section{Figure B.1 \\ Best-Practice Business Loan Nonperformance Frontier ${ }^{35}$}

This figure illustrates the best-practice minimum ratio of nonperforming business loans to total business loans that is obtained by stochastic frontier estimation of the relationship between the nonperforming business loan ratio and total business loans (expressed in 100 billions), controlling for the volume of business loans, the volume of all loan types, the average contractual loan rate on business loans, and the GDP growth rate and market concentration in the bank's markets. The error term, $\varepsilon_{i}=v_{i}+\mu_{i}$, is a composite term used to distinguish statistical noise, $v_{i} \sim$ iid $N\left(0, \sigma_{v}^{2}\right)$, from the term, $\mu_{i}$, which is distributed exponentially, $\mu_{i}(>0) \sim \theta \exp (-\theta u)$, that measures the systematic excess business nonperformance from bank i's best-practice minimum business nonperforming loan ratio. The best-practice minimum nonperforming loan ratio is given by the value on the deterministic kernel of the stochastic frontier.

In this example, bank $i$ has total business loans of $\$ 8$ billion and experiences an observed nonperforming business loan ratio $\left(\mathrm{NP}_{\mathrm{i}}\right)$ of 0.030 . Its $N \mathrm{P}_{\mathrm{i}}$ adjusted for statistical noise is $N P_{\mathrm{i}}-v_{i}=$ 0.025 , which is an excess of 0.015 over its best-practice minimum of 0.01 .

\section{Nonperforming}

Business Loans/

Total Business Loans (NP)
Best-Practice NP Frontier: $\mathrm{NP}_{i}=\mathbf{X} \bullet \boldsymbol{\beta}$

where $\mathrm{X}$ includes volume of business loans, volume of all loan types, average contractual business loan rate, GDP growth rate in bank's markets, and market concentration

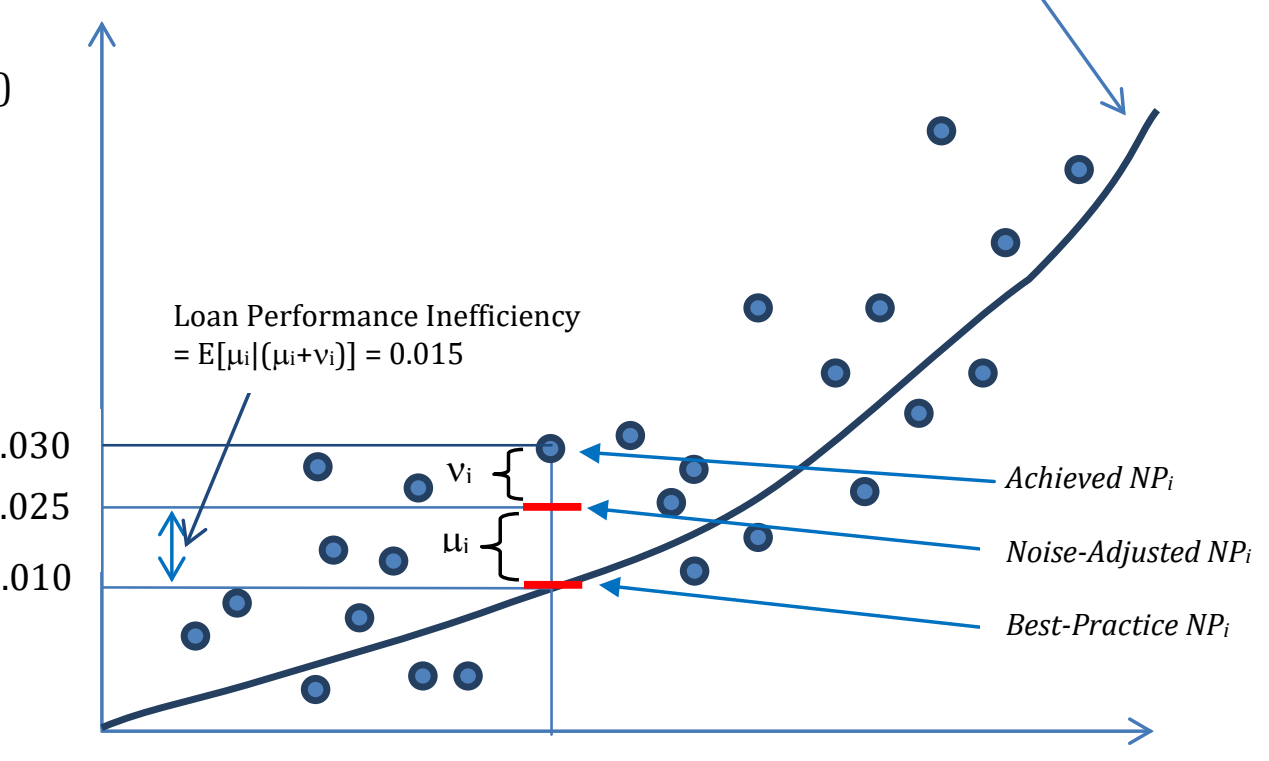

8.0

Total Business Loan Volume (in billions)

${ }^{35}$ Adapted from Hughes and Moon (2017). 


\section{Table B1 \\ Stochastic Frontier Estimation of Commercial and Industrial Loan Nonperformance}

The data set includes 619 top-tier bank holding companies at the end of 2013 with data on the average contractual loan rate on business loans and plausible values of nonperforming business loans. Banks with values of nonperforming business loans to total business loans less than 0.001 and greater than 0.25 were trimmed.

\begin{tabular}{|c|c|c|c|}
\hline Parameter & Variable & $\begin{array}{c}\text { Coefficient } \\
\text { Estimate }\end{array}$ & $\operatorname{Pr}(>|t|)$ \\
\hline$\beta_{1}$ & Business Loans i $_{\mathrm{i}}$ (scaled) & -0.582107 & 0.000051 \\
\hline$\beta_{2}$ & [Business Loans $_{\mathrm{i}}\left(\right.$ scaled)] ${ }^{2}$ & 2.245355 & 0.035777 \\
\hline$\beta_{3}$ & Total Loans (scaled) & 0.125135 & 0.000007 \\
\hline$\beta_{4}$ & {$[\text { Total Loansi }(\text { scaled })]^{2}$} & -0.195548 & 0.022056 \\
\hline$\beta_{5}$ & [Business Loans ${ }_{\mathrm{i}}\left(\right.$ scaled)] $\times\left[\right.$ Business Loan Rate $\left.{ }_{\mathrm{i}}\right]$ & 11.686910 & 0.008653 \\
\hline$\beta_{6}$ & [Business Loans ${ }_{\mathrm{i}}($ scaled $\left.)\right] \times\left[\right.$ GDP Growth Rate $\left._{\mathrm{i}}\right]$ & -0.013310 & 0.130716 \\
\hline$\beta_{7}$ & [Business Loans $\mathrm{i}_{\mathrm{i}}($ scaled $\left.)\right] \times[$ Herfindahl Index $]$ & -1.847575 & 0.000071 \\
\hline$\beta_{8}$ & {$\left[\right.$ Business Loan Rate $\left.{ }_{i}\right] \times\left[\right.$ Herfindahl Index $\left.{ }_{i}\right]$} & 0.197388 & 0.001387 \\
\hline$\sigma_{\mu}=1 / \theta$ & & 0.025025 & 0.000000 \\
\hline$\sigma_{v}$ & & 0.001044 & 0.001338 \\
\hline
\end{tabular}

\section{Table B2 \\ Stochastic Frontier Estimation of Commercial Real Estate Loan Nonperformance}

The data set includes 663 top-tier bank holding companies at the end of 2013 with plausible values of nonperforming commercial real estate loans. Banks with 0 values of nonperforming commercial real estate (CRE) loans and banks whose ratios of CRE nonperforming loans exceed 0.40 were trimmed.

\begin{tabular}{|c|c|c|c|}
\hline Parameter & Variable & $\begin{array}{l}\text { Coefficient } \\
\text { Estimate }\end{array}$ & $\operatorname{Pr}(>|t|)$ \\
\hline$\beta_{1}$ & CRE Loans i $_{\text {(scaled) }}$ & 0.747581 & 0.000000 \\
\hline$\beta_{2}$ & CRE Loans $_{\mathrm{i}}$ (scaled)] $]^{2}$ & -0.189158 & 0.901903 \\
\hline$\beta_{3}$ & Total Loans $_{\mathrm{i}}$ (scaled) & -0.006967 & 0.229286 \\
\hline$\beta_{4}$ & {$\left[\text { Total Loans } \text { i }_{\mathrm{i}} \text { (scaled) }\right]^{2}$} & -0.021185 & 0.896806 \\
\hline$\beta_{5}$ & {$\left[\right.$ CRE Loans ${ }_{i}($ scaled $\left.)\right] \times[$ CRE Loan Rate $]$} & 16.582116 & 0.000000 \\
\hline$\beta_{6}$ & [CRE Loans ${ }_{\mathrm{i}}($ scaled$\left.)\right] \times\left[\right.$ GDP Growth Rate $\left._{\mathrm{i}}\right]$ & -0.189680 & 0.000000 \\
\hline$\beta_{7}$ & {$\left[\right.$ CRE Loans ${ }_{i}($ scaled $\left.)\right] \times[$ Herfindahl Index $]$} & -5.107528 & 0.000000 \\
\hline$\beta_{8}$ & {$[$ CRE Loan Rate $]$ i $\times[$ Herfindahl Index $]$} & 0.550731 & 0.000190 \\
\hline$\sigma_{\mu}=1 / \theta$ & & 0.036006 & 0.000000 \\
\hline$\sigma_{v}$ & & 0.002386 & 0.000000 \\
\hline
\end{tabular}

